This report has been reproduced directly from the best available copy.

Available to DOE and DOE contractors from the Otfice of Scientific and Technical Information, P.O. Box 62, Oak Ridge, TN $3783 i$; prices avallable from (615) 576-8401, FTS 626-8401.

Avallable to the public from the National Technical Information Service, U.S. Department of Commerce, 5285 Port Royal Rd.. Springfield, VA 22161.

This report was prepared as an account of work sponsored by an agency of the United States Government. Neither the United States Government nor any agency thereof, nor any of their employees, makes any warranty, express or implied, or assumes any legal liability or responsibility for tive accuracy, completeness, or usefulness of any information, apparatus, produci, or procese disclosed, or represents that its use would not infringe privately owned rights. Reference herein to any specific commerclal product, process, or service by trade name, trademark, manufacturer, or otherwise, does not necessarily constitute or imply its endorsement, recommendation, or favoring by the United States Government or any agency thereof. The vif $\ldots$ and opinions of authors expressed herein do not necessarily state or reflect those of the United States Government or any agelisy thereot. 


\title{
OPTIONS FOR TREATING HIGH-TEMPERATURE GAS-COOLED \\ REACTOR FUEL FOR REPOSITORY DISPOSAL
}

\author{
A. L. Lotts** \\ W. D. Bond \\ C. W. Forsberg \\ R. W. Glass* \\ F. E. Harrington** \\ G. E. Michaels \\ K. J. Notz \\ R. G. Wymer** \\ Chemical Technology Division \\ *Engineering Division \\ ${ }^{* *}$ Consultant
}

Date Published: February 1992

Prepared by the

OAK RIDGE NATIONAL LABORATORY

\section{MASTER}

Oak Ridgc, Tennessee 37831-2008 managed by

MARTIN MARIETTA ENERGY SYSTEMS, INC.

for the

U.S. DEPARTMENT OF ENERGY

under contract DE-AC05-84OR21400 


\section{CONTENTS}

FIGURES $\ldots \ldots \ldots \ldots \ldots \ldots \ldots \ldots \ldots \ldots \ldots \ldots \ldots \ldots \ldots$ vii

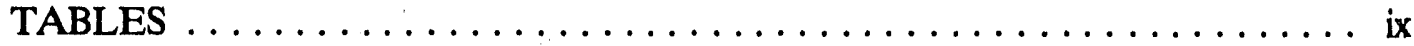

ABSTRACT $\ldots \ldots \ldots \ldots \ldots \ldots \ldots \ldots \ldots \ldots \ldots \ldots \ldots \ldots \ldots \ldots \ldots$

1. INTRODUCTION $\ldots \ldots \ldots \ldots \ldots \ldots \ldots \ldots \ldots \ldots \ldots \ldots \ldots$

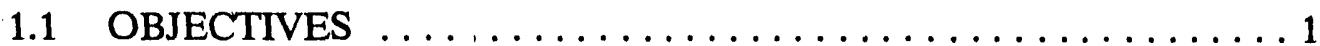

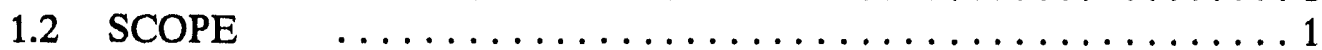

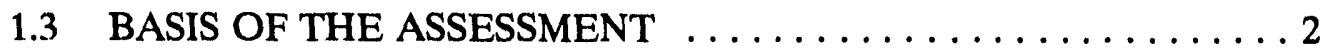

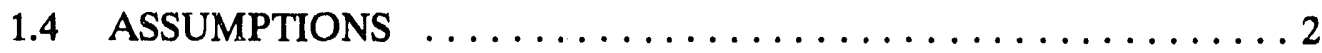

1.5 UNIQUE ASPECTS OF HTGR FUEL $\ldots \ldots \ldots \ldots \ldots \ldots$

2. INSTITUTIONAL ISSUES $\ldots \ldots \ldots \ldots \ldots \ldots \ldots \ldots \ldots \ldots \ldots$

2.1 REPOSITORY WASTE ACCEPTANCE CRITERIA ........5

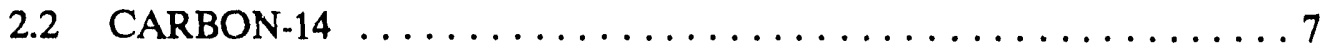

2.3 APPLICABLE RADIATION PROTECTION STANDARDS $\ldots \ldots 7$

2.4 DISPOSAL OF RADIOACTIVE PROCESSING WASTE $\ldots \ldots \ldots 7$

2.5 SAFEGUARDS: ISSUES RELATED TO NON-WEAPONS

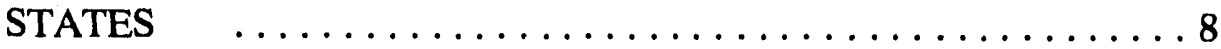

2.6 REFERENCES $\ldots \ldots \ldots \ldots \ldots \ldots \ldots \ldots \ldots \ldots \ldots \ldots \ldots \ldots \ldots$

3. DESCRIPTION OF HTGR FUELS $\ldots \ldots \ldots \ldots \ldots \ldots \ldots \ldots \ldots \ldots$

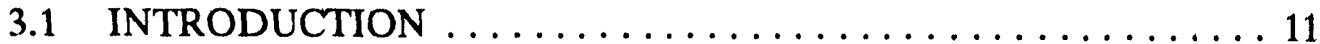

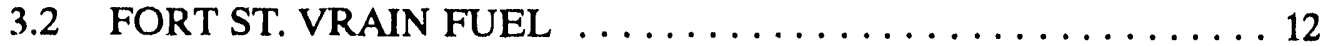

3.2.1 Physical and Chemical Description of Fort St. Vrain Fuel . . . 12

3.2.2 Quantities of Fort St. Vrain Fuel . . . . . . . . . . . 17

3.2.3 Radiological Properties of Fort St. Vrain Fuel . . . . . . 19

3.3 PEACH BOTTOM-1 REACTOR FUEL . . . . . . . . . . . 22

3.4 COMPARISON TO OTHER NON.STANDARD FUELS . . . . . . 24

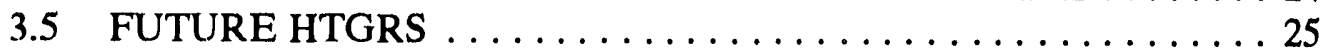

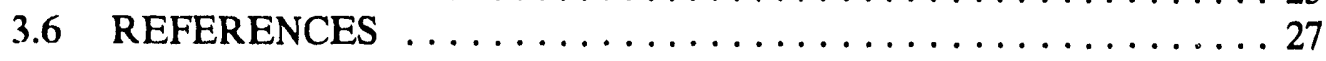

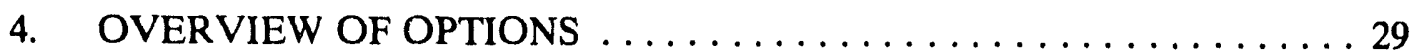

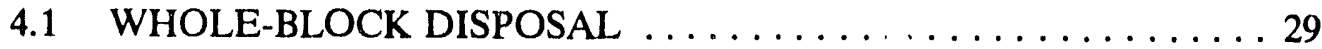

4.2 DISPOSAL WITH PRIOR REMOVA I OF GRAPHITE . . . . . 33

4.3 DISPOSAL WITH DISSOLUTION JF SPENT FUEL . . . . . . 34

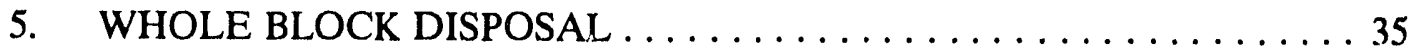

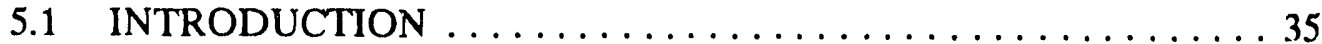

5.2 ACCEPTABILITY OF WHOLE BLOCK DISPOSAL . . . . . . . 35

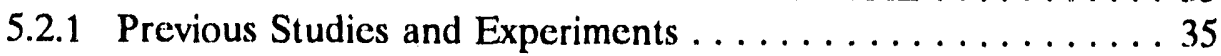

5.2.2 Comparison of the Characteristics of HTGR Spent

Fuel with Repository Acceptar،e Requirements . . . . . . . 37 
5.2.2.1 Allowable Release Rates for Radionuclides from the Repository . . . . . . . . . . . . . 37

5.2.2.2 Allowable Organics in a Repository ......... 39

5.2.2.3 Combustibility ................. 40

5.2.3 Comparison of HTGR and LWR Spent Fuel

Under Repository Conditions . . . . . . . . . . 41

5.2.3.1 Physical Effects ................ 41

5.2.3.2 Chemical Effects ............... 42

5.2.3.3 Combined Physical Form and Chemical Effects ... 44

5.2.4 Options for Improved Whole Block Disposal . . . . . . . . . 44

5.3 REPOSITORY ENGINEERING AND COST

CONSIDERATIONS ................... 45

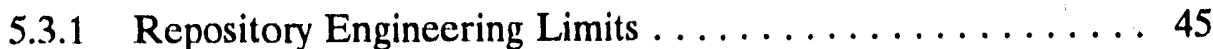

5.3 .2 Heat Limits ......................... 46

5.3 .3 Volume Limits ....................... 47

5.3 .4 Waste Form ..................... 48

5.3.5 Relative HTGR and LWR Spent Fuel Disposal Costs . . . 49

5.4 REFERENCES ........................ 50

6. DISPOSAL WITH REMOVAL OF GRAPHITE $\ldots \ldots \ldots \ldots \ldots \ldots \ldots$

6.1 OPTIONS AVAILABLE $\ldots \ldots \ldots \ldots \ldots \ldots \ldots \ldots \ldots \ldots$

6.2 PHYSICAL SEPARATION OF GRAPHITE $\ldots \ldots \ldots \ldots \ldots \ldots .53$

6.3 CHEMICAL SEPARATION OF GRAPHITE (BURNING) . . . . 54

6.4 POSSIBLE IMPROVEMENTS TO FUTURE HTGR FUEL . . . 55

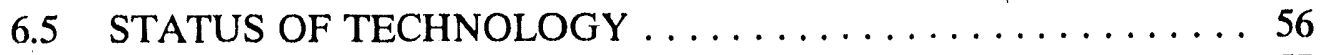

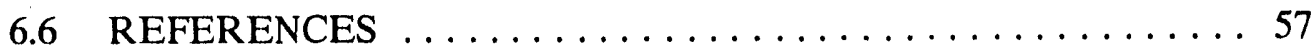

7. DISPOSAL WITH DISSOLUTION OF FUEL . . . . . . . . . 59

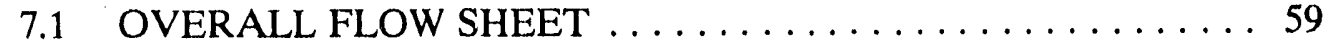

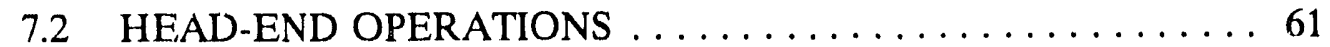

7.3 SOLVENT EXTRACTIONS $\ldots \ldots \ldots \ldots \ldots \ldots \ldots \ldots \ldots \ldots$

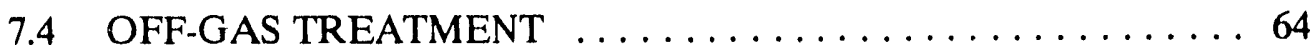

7.5 LIQUID AND SOLID WASTE PROCESSING . . . . . . . . 64

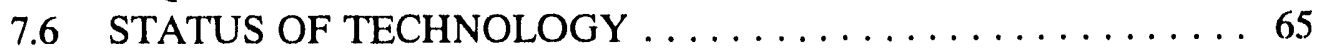

7.7 REFERENCES .....................66

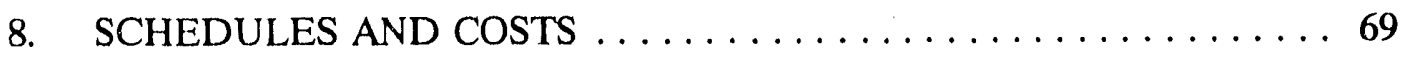

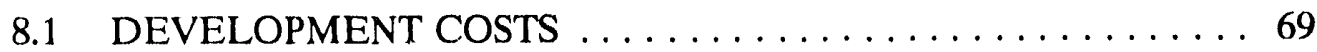

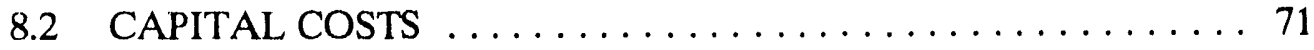

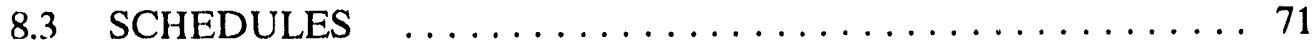

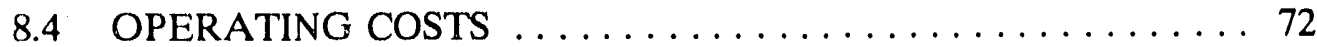

8.5 SUITABILITY OF WASTE FOR THE REPOSITORY . . . . . 72

9. CONCLUSIONS $\ldots \ldots \ldots \ldots \ldots \ldots \ldots \ldots \ldots \ldots \ldots \ldots$

9.1 CONCLUSIONS ON WHOLE BLOCK HTGR SPENT

FUEL DISPOSAL $\ldots \ldots \ldots \ldots \ldots \ldots \ldots$ 
9.2 CONCLUSIONS ON DISPOSAL AFTER SEPARATION OF GRAPHITE AND SPENT FUEL . . . . . . . . . . . . . 74

9.3 CONCLUSIONS ON DISPOSAL WITH DISSOLUTION

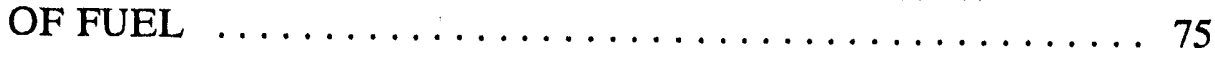

APPENDIX A: DETAILS OF FORT ST. VRAIN FUEL $\ldots \ldots \ldots \ldots 77$

A.1 GRAPHITE ...................... 79

A.2 VARIATION IN DESIGN OF FUEL BLOCKS ... 79

A.3 FUEL STICK IMPURITY SPECIFICATIONS . . . 80

A.4 WEIGHTS OF FUEL BLOCKS AND

COMPONENTS .................. 80

A.5 RESULTS OF BURNUP CALCULATIONS .... 80

A.6 RADIOLOGICAL CHARACTERISTICS OF THERMAL POWER $\ldots \ldots \ldots \ldots \ldots \ldots . \ldots 84$

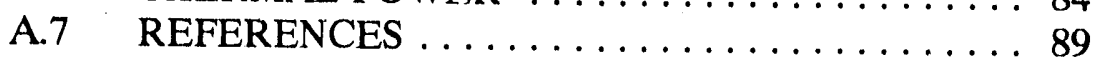

APPENDIX B: OXIDATION OF URANIUM DIOXIDE . . . . . 91

B.1 REFERENCES .................... 98

APPENDIX C: OXIDATION OF GRAPHITE ............. 101

C.1 REFERENCES . . . . . . . . . . . . . . . . 107 


\section{FIGURES}

Fig. 3.1. FSV standard fuel element $\ldots \ldots \ldots \ldots \ldots \ldots \ldots \ldots$

Fig. 3.2. HTGR coated fuel particles $(100 \mathrm{X}) \ldots \ldots \ldots \ldots \ldots \ldots$

Fig. 3.3. Peach Bottom Unit 1, core 1 fuel element $\ldots \ldots \ldots \ldots \ldots$

Fig. 4.1. Options for processing of HTGR spent fuel for repository disposal $\ldots \ldots \ldots \ldots \ldots \ldots \ldots \ldots \ldots \ldots$ ()

Fig. 4.2. United States Yucca Mountain project reference spent fuel container $\ldots \ldots \ldots \ldots \ldots \ldots \ldots \ldots \ldots \ldots \ldots \ldots \ldots \ldots$

Fig. 4.3. Example HTGR spent fuel container $\ldots \ldots \ldots \ldots \ldots \ldots \ldots \ldots \ldots$

Fig. 7.1. HTGR reprocessing flow sheet $\ldots \ldots \ldots \ldots \ldots \ldots \ldots \ldots \ldots \ldots \ldots \ldots$

Fig. 7.2. Solvent extraction processing and oxide conversion $\ldots \ldots \ldots \ldots 2$

Fig. A.1. Control fuel elements and surveillance control

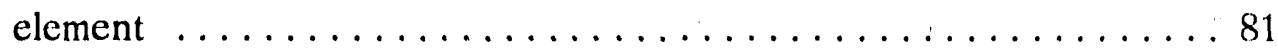

Fig. A.2. Decay heat for FSV spent fuel. (Basis:

1 MTIHM irradiated to $100,000 \mathrm{MWd} / \mathrm{MTIHM}) \ldots \ldots \ldots \ldots 8$

Fig. B.1. Air oxidation of $\mathrm{UO}_{2}$ to $\mathrm{U}_{3} \mathrm{O}_{7}$ as a function

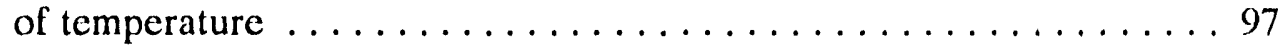

Fig. C.1. Oxidation of graphite at an oxygen pressure of $0.1 \mathrm{~atm} \ldots \ldots \ldots \ldots \ldots \ldots$. . . . . . . . . . . . . . . . 104 


\section{TABLES}

Table 3.1. Historical and projected spent fuel discharged from the

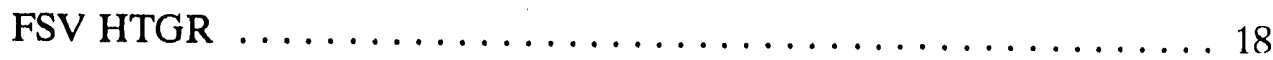

Table 3.2. Quantities of radioactive nuclides in HTGR fuel . . . . . . . . . . . 19

Table 3.3. Production of ${ }^{14} \mathrm{C}$ in graphite and fuel of HTGRs $\ldots \ldots \ldots \ldots \ldots 21$

Table 3.4. Estimated number of canisters required for repository disposal of various non-LWR and special LWR spent fuels . . . . . 26

Table 8.1. Estimated requirements for now and future options $\ldots \ldots \ldots \ldots 70$

Table A.1. FSV fuel element component weights $\ldots \ldots \ldots \ldots \ldots \ldots \ldots$

Table A.2. Sample of fuel accountability data $\ldots \ldots \ldots \ldots \ldots \ldots \ldots \ldots$

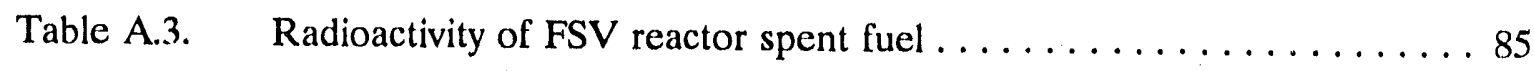

Table B.1. Oxidation rate of $\mathrm{UO}_{2}$ to $\mathrm{U}_{3} \mathrm{O}_{7} \ldots \ldots \ldots \ldots \ldots \ldots \ldots \ldots \ldots \ldots \ldots \ldots$

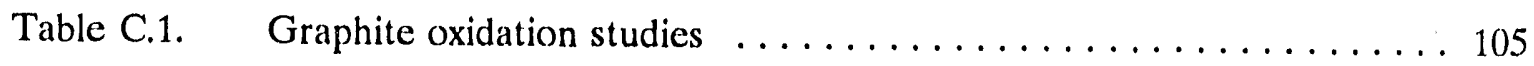




\begin{abstract}
This report describes the options that can reasonably be considered for disposal of hightemperature gas-cooled reactor (HTGR) fuel in a repository. The options include wholeblock disposal, disposal with removal of graphite (either mechanically or by burning), and reprocessing of spent fuel to separate the fuel and fission products. The report summarizes what is known about the options without extensively projecting or analyzing actual performance of waste forms in a repository. The report also summarizes the processes involved to convert spent HTGR fuel into the various waste forms and projects relative schedules and costs for deployment of the various options.
\end{abstract}

Fort St. Vrain Reactor fuel, which utilizes highly-enriched ${ }^{235} U$ (plus thorium) and is contained in a prismatic graphite block geometry, was used as the baseline for evaluation, but the major conclusions would not be significantly different for low- or medium-enriched ${ }^{235} \mathrm{U}$ (without thorium) or for the German pebble-bed fuel. Future U.S. HTGRs will be based on the Fort St. Vrain (FSV) fuel form. The whole block appears to be a satisfactory waste form for disposal in a repository and may perform better than light-water reactor (LWR) spent fuel. From the standpoint of process cost and schedule (not considering repository cost or value of fuel that might be recycled), the options are ranked as follows in order of increased cost and longer schedule to perform the option: (1) whole block, (2a) physical separation, ( $2 \mathrm{~b})$ chemical separation, and (3) complete chemical processing. 


\section{INTRODUCTION}

The purpose of this report is to (1) present the options for treating high-temperature gascooled reactor (HTGR) spent fuel for disposal in a repository and (2) to provide a preliminary evaluation of the feasibility of these options and a comparison of their relative advantages and disadvantages.

\subsection{OBJECTIVES}

The objectives of the assessment described in this report were to address the alternative waste disposal strategies that are reasonably possible for disposing of HTGR fuel, to set forth the processing steps that would be required for each, to assess the general status of the technology for accomplishing the processing, and to assess costs and schedules of various elements (e.g., development, pilot-scale work, capital facilities and equipment, and production operations) of the infrastructure required to bring each option to realization.

\subsection{SCOPE}

This report covers HTGR fuels that have been, and might again be, produced in the United States (U.S.) which are based on the prismatic fuel design. The chemistry and materials properties of prismatic fuel are very similar to the other major option for fuel geometry, pebble-bed fuel, which is the design on which German HTGRs are based. Thus, the principles applied in this report would, in general, apply to pebble-bed fuel as well as the prismatic fuel. The report covers two scenarios: a now scenario, representing the present situation with no future deployment of HTGRs, and a future scenario, representing a deployment of HTGRs at a level an order of magnitude greater than the now scenario. Any future defense production reactor capability is assumed to be bounded as a case by the future scenario. Future commercial power reactor deployment could exceed the future scenario by an additional order of magnitude. 


\subsection{BASIS OF THE ASSESSMENT}

The assessment relied primarily upon the collective judgment of the authors, most of whom were previously substantial contributors and leaders in the development of fuel technology and processing technology for HTGR fuels. The assessment is, therefore, largely based on the substantial body of data and information from fuel cycle development that occurred until the early 1980s when most fuel cycle work in this country was terminated. In addition, some other information on fuel performance and properties of materials that has been published since then was used.

The assessment was necessarily limited by the resources and time available for the study. Therefore, the amount of effort expended is a limitation on how the study can be used. The authors have summarized what they already knew or what is readily available from the literature. Some cursory analyses were performed when it was possible to do so without extensive effort. Extensive analyses, such as would be necessary to prove the basis and validity of suggested courses of action for placing HTGR fucl in a repository, were not undertaken. Considering these limitations, it is proper to use the report as a basis for alternatives that should be considered for more in-depth study and analysis and as a guide to pertinent factors.

\subsection{ASSUMPTIONS}

It was assumed that the HTGR fuel to be treated or processed would be similar to Fort St. Vrain (FSV) fuel. It was also assumed that any necessary development could be carried out at existing facilities and that development costs would be limited to equipment and studies to obtain essential data. For full-scale processing operations, it was assumed that new processing facilities (and casks) would be required. Further, it was assumed that suitable facilities would exist at the future repository for unloading and placement of the spent fuel; therefore, costs at the repository were not addressed. However, parameters having a significant bearing on repository design, such as thermal load and volume occupied per unit 
of fuel, were considered in developing the recommended courses of action. FSV fuel was used as the baseline for this preliminary evaluation of the options for spent fuel disposal.

\subsection{UNIQUE ASPECTS OF HTGR FUEL}

The fuel used in HTGRs most obviously differs from light-water reactor (LWR) fuel in that it is contained in massive quantities of graphite. Of equal importance, the fuel consists of small particles (spheres of the order of $0.5-\mathrm{mm}$ diam) of uranium oxide or carbide. The particles are coated with thin layers of pyrolytic carbon (pyrocarbon) and silicon carbide, which serve as tiny pressure vessels to contain fission products and fuel. In FSV fuel elements, the coated particles are bound in a carbonized matrix which forms fuel rods that are loaded into large graphite prisms. The large graphite prisms (or blocks) are the pnysical forms that are handled in reactor loading and unloading operations. Existing HTGRs, such as the FSV reactor, were based on the thorium fuel cycle in which fissile ${ }^{233} \mathrm{U}$ is produced from ${ }^{232} \mathrm{Th}$. In this case, there were "fertile" particles containing only thorium, as well as "fissile" particles. Similar concepts with two-particle systems can also be used for the uranium-plutonium (U-Pu) cycle. For a once-through fuel cycle, there would be no need for separate fissile and fertile particles, except for utilizing fertile particles to optimize core design.

The solid graphite fuel form, which is capable of operating at very high temperatures (up to approximately $1200^{\circ} \mathrm{C}$ during normal reactor operation and up to $1600^{\circ} \mathrm{C}$ during short-term, severe accidents) in the reactor, may take any of a variety of physical shapes. Three fuelbearing configurations have been used in HTGRs: long, slender graphite prisms (in Peach Bottom-1); graphite spheres about $6 \mathrm{~cm}$ in diam in the German arbeitsgemeinschaft versuchsreaktor GmbH (AVR) and thorium high-temperature reactor (THTR); and hexagonal graphite prisms $35-\mathrm{cm}$ wide and $76-\mathrm{cm}$ long (in FSV). In the case of the 6-cm spheres, the fuel particles are dispersed uniformly in the sphere, except in the outermost layer of the sphere that is a protective region of urifueled graphite. In the case of the prism-shaped fuel, the fuel particles are first bound into rods that are subsequently carbonized. These fuel rods are placed into holes drilled in tha prism. 
Coating the fissile particles with two layers of pyrolytic carbon with a silicon carbide layer sandwiched in between makes them very resistant to failure during reactor operation and, thus, makes for a very clean-operating reactor-even at very high temperatures. On the other hand, the carbon and silicon carbide coatings on the spheres and the graphite matrix in which they are bound make this fuel form incompatible with conventional LWR fuel head-end reprocessing techniques. LWR head-end reprocessing consists of cutting through the metal cladding on the $\mathrm{UO}_{2}$ pellets and then dissolving the spent fuel directly in nitric acid. Thus, a radically different head-end treatment is necessary for HTGR fuel if the spent fuel is to be placed into solution. However, the subsequent solvent extraction operations are not substantia!ly different from the conventional Purex proress. 


\section{INSTITUTIONAL ISSUES}

\subsection{REPOSITORY WASTE ACCEPTANCE CRITERIA}

Waste acceptance criteria for the presently planned underground waste disposal facilities have been conceived primarily with the large volume waste forms in mind, although it has been recognized that there are a number of less common forms of spent fuel that must be accommodated. While the criteria were made quite general to cover as many unanticipated situations as possible, the special case of spent HTGR fuel was not specifically considered. ${ }^{1}$ Therefore, the disposal criteria must be examined carefully to understand their implication for HTGR fuels.

In the U.S. there are three levels of standards and regulations that determine whether a particular waste form can be accepted by a high-level waste (HLW) repository for disnosal. At the top level are the U.S. Environmental Protection Agency (EPA) standards of performance (40 CFR 191) applicable to any disposal method for HLW or spent fuel. Next are the U.S. Nuclear Regulatory Commission (NRC) implementing regulations (10 CFR 60), that are designed to meet the EPA standards for the disposal of spent fuel and HLW in a geological repository. Finally, the waste acceptance criteria defined by U.S. Department of Energy (DOE), the repository operator, are designed to meet the NRC regulations. The EPA standards and NRC regulations are published, but the DOE waste acceptance criteria for spent fuel are still under development. Preliminary waste acceptance criteria have been published for borosilicate glass from the Savannah River site ${ }^{2}$ and from the former commercial reprocessing facility located at West Valley. ${ }^{3}$

The existing standards and regulations include three requirements that might impact acceptance of whole HTGR fuel blocks: (a) allowable release rates of radionuclides to the environment, (b) regulations on organics, and (c) regulations on combustibility of wastes. 
EPA standards (10 CFR 191.13) limit the allowable releases of radionuclides from the repository to the accessible environment in terms of curies of specific radionuclides per 1,000 metric tons of heavy metal (MTHM) over a period of 10,000 years after placement of the waste in the repository. NRC regulations (10 CFR 60.113:a:ii:B) limit releases from the "engineered barrier system" to $10^{-5}$ fraction per year of the radionuclide inventory that exists in the repository at 1000 years after repository closure. While the EPA standards refer to the performance of the entire repository system and the NRC regulations refer to the engineered waste package, demonstrating compliance is greatly simplified with a good waste form. The performance of HTGR spent fuel without waste packaging is compaied in this report to the EPA standards and the NRC regulaticns and is also compared to LWR fuel, which provides an informal standard for measurement of performance of other waste forms. The required waste package and the larger engineered barrier system can significantly improve performance over that of the fuel form itself to meet regulatory requirements.

The potential repository site currently being investigated for the U.S. is at Yucca Mountain in Nevada. This is a non-typical site in that the repository is above the water table (dry) and the repository horizon is a chemically oxidizing environment. The site is not yet characterized, but available information indicates an air-like chemical environment for the waste and waste package, subject to possible flooding or water percolation. It is under these conditions that long-term integrity of the waste must be ensured.

The NRC limits combustible radioactive wastes (10 CFR 61.135:C:3) in a repository. Specifically, "all combustible radioactive wastes shall be reduced to a noncombustible form unless it can be demonstrated that a fire involving the waste packages containing combustibles will not compromise the integrity of other waste packages, adversely affect any structures, systems, or components important to safety, or compromise the ability of the underground facility to contribute to waste isolation." The graphite and carbon in HTGR fuel must be evaluated in this context. 


\subsection{CARBON-14}

An unusual aspect of HTGR spent fuel is the relatively high level of the isotope ${ }^{14} \mathrm{C}$ as compared to LWR spent fuel. The ${ }^{14} \mathrm{C}$ isotope is produced by neutron irradiation of nitrogen ${ }^{14} \mathrm{~N}(n, p){ }^{14} \mathrm{C}$, and of carbon ${ }^{13} \mathrm{C}(\mathrm{n}$, gamma $){ }^{14} \mathrm{C}$. In an HTGR fuel assembly, the presence of atmospheric nitrogen introduced during the fabrication of the fuel and graphite matrix, and the rare ${ }^{13} \mathrm{C}$ isotope that is naturally present in the graphite, represent sources of ${ }^{14} \mathrm{C}$ production in irradiated assemblies. The relatively long half-life of ${ }^{14} \mathrm{C}$ (5730 years) makes it a potential long-term health hazard. Combustion of the graphite could convert any ${ }^{14} \mathrm{C}$ present into ${ }^{14} \mathrm{CO}_{2}$, which could potentially pose : radiation exposure hazard to the general public if released into the atmosphe:e.

The concentration limit for Class $C$ low-level radioactive waste (LLW) is $8 \mathrm{Ci} / \mathrm{m}^{3}$, the Class A LLW limit is $0.8 \mathrm{Ci} / \mathrm{m}^{3}$. On the basis of ${ }^{14} \mathrm{C}$ concentration alone, it appears that the graphite block has the potential, dependent upon fission product contamination, of qualifying as Class C LLW.

\subsection{APPLICABLE RADIATION PROTECTION STANDARDS}

In the recent revision of radiation protection standards for the public in $10 \mathrm{CFR} 20{ }^{4}$ the NRC established new limits on average annual concentrations of radionuclides in gaseous effluents at the boundary of any unrestricted area around a licensed commercial facility. In 40 CFR 61, the EPA promulgated standards for airborne emissions of radionuclides under authority of the Clean Air Act. ${ }^{5}$ In contrast to the concentration limits in 10 CFR 20, the dose limit in 40 CFR 61 applies where members of the public reside or could otherwise receive exposures.

\subsection{DISPOSAL OF RADIOACTIVE PROCESSING WASTE}

If the graphite block is not separated from the spent fuel, the spent fuel element: must, of course, be disposed at the proposed repository. 
HTGR fuel elements do provide the option of separating the graphite from the fuel rods or particles, thus enabling the consideration of using a less expensive method for disposal of the graphite. However, if the sum of the ${ }^{14} \mathrm{C}$ concentration and the fission product contamination exeseds the limit for snallow land disposal as LLW, there is no need to separate the fuel from the graphite because the repository (Yucca Mountain) is the only place that would be authorized for its disposal. The EPA standards applicable to the repository are undergoing revision, but limits on cumulative releases for the HLW repository are not expected to be changed. These releases are $100 \mathrm{Ci}$ of ${ }^{14} \mathrm{C}$ accumulated over 10,000 years per 1,000 MTHM in spent fuel exposed to 25,000 to $40,000 \mathrm{MWd}$ of burnup, or the HLWs from the same amount of liel.

If graphite waste from an HTGR fuel cycle is classified as LLW, then near-surface disposal may be an option. If the graphite is separated from the fueled microspheres, near-surface disposal may be acceptable, assuming that the fuel has performed with such integrity that the graphite is not significantly contaminated with fission products or actinides. If the carbon dioxide $\left(\mathrm{CO}_{2}\right)$ produced by burning the graphite was converted to a solid form such as calcium carbonate $\left(\mathrm{CaCO}_{3}\right)$, the $\mathrm{CaCO}_{3}$ could be disposed as LLW. The EPA is currently developing environmental standards for disposal of LLW in 40 CFR 193 that would apply to HTGR LLW wastes.

\subsection{SAFEGUARDS: ISSUES RELATED TO NON-WEAPONS STATES}

A criticism often leveled at the once-through fuel cycle for LWRs is that the disposal of fuel elements in eifect constitute a "plutonium mine" and, therefore, pose a greater proliferation risk than fuel cycles that recover plutonium by reprocessing and then recycle it back into reactors. This criticism, which has importance in the context of non-weapons states using the once-through fuel cycle for their power reactors, has some merit. The same kind of considerations apply to the several fuel cycle options for HTGRs. If the fuel blocks (or spheres, as in the case of fucl of the type used in the German program) are stored whole, or if the bulk of the graphite is removed and the separated fuel particles stored, then the 
possibility exists of subsequently recovering the contained fissile material for use in weapons production.

While clandestine cecovery of plutonium should not be a problem for HTGR fuels stored as waste in a U.S. federal repository, it is conceivable that it could be a problem if the U.S. approach to HTGR spent fuel management is adopted by non-weapons states. Several countries are considering HTGRs for power production and process heat, and intreduction of HTGRs by the U.S. could prompt those countries to build HTGRs. Unless these countries practiced fuel reprocessing they could accumulate over time a significant amount of plutonium in the fuel blocks or separated particles stored as waste. However, the "quality" of the plutonium produced in commercial HTGRs is relatively low because of the high content of ${ }^{240} \mathrm{Pu}$ and ${ }^{242} \mathrm{Pu}$. This high plutonium content is due to the high fuel exposure of approximately $100,000 \mathrm{MWd} / \mathrm{MTIHM}$ (metric tons initial heavy metal) and the relatively high neutron energy spectrum that increases the probability that ${ }^{239} \mathrm{Pu}$ will be transmuted $10{ }^{240} \mathrm{Pu}$.

Assuming that the HTGRs displaced LWRs that would have otherwise been built in these non-weapons states, the issue becomes, Which is the greater proliferation risk, disposing of LWR fuel or disposing of HTGR fuel in a waste repository? Because HTGR fuel is substantially more difficult to reprocess than LWR fuel and because the quality of the plutonium is relatively low, HTGR spent fuel storage can be expected to pose less risk. However, a more careful study is in order if large scale deployment of HTGRs is planned.

\subsection{REFERENCES}

1. "Design Criteria For The Waste Package," 10 CFR 60.135, Criteria for the Waste Package and Its Components, (1991), paragraph (3).

2. U.S. Department of Energy, Waste Acceptance Preliminary Specifications for the Defense Waste Processing Facility High-Level Waste Form, Revision 1, DOE/RW-0260 (July 1989). 
3. U.S. Department of Encrgy, Waste Acceptance Preliminary Specifications for the West Valley Demonstration Project High-Level Waste Form, Revision 1, DOE/RW-()261 (January 1990).

4. U.S. Nuclear Regulatory Commission, 10 CFR Parts 2, 19, 20, 30, 31, 32, 34, 35, 40, 50, 61, and 70, Standards for Protection Against Radiation, Final Rule, Federal Register $56,23360(1991)$.

5. U.S. Environmental Protection Agency, 40 CFR Part 61, National Emission Standards for Hazardous Air Pollutants: Regulation of Radionuclides, Final Rule, Federal Register 54, 51654 (1990). 


\section{DESCRIPTION OF HTGR FUELS}

\subsection{INTRODUCTION}

This chapter concentrates on FSV fuel for a number of reasons: more is known about it than other HTGR fucl; more of it exists than other HTGR fiel; it is the prototype for future HTGK fuel in the U.S.; and, even though future fuel will differ in some ways, FSV fuel embodies the essential characteristics of such fuel relevant to eventual disposal. The only ol he' domestic HTGR, Peach Bottom-1, used a different configuration but the basic preperties aie similar to FSV fuel. In Germany, the pebble-bed configuration uses small spheres instead of large hexagonal prisms but, even here, the basic properties are similar to FSV fuel.

This chapter also describes some of the major differences between HTGR and LWR spent fuels. Since a future repository will be designed for LWR fuel, these differences may be quite important. Some of the more obvious differences are the presence of very large amounis of graphite in the HTGR, fuel in the form of silicon carbide-coated microspheres rather than zircaloy-encased pellets, and uranium present as the carbide rather than the oxide. Less obvious differences are the larger quantities of ${ }^{14} \mathrm{C}$ in HTGR fuel, and (for prior HTGRs) the eventual transition to the ${ }^{233} \mathrm{U}$ fuel cycle with its concomitant generation of ${ }^{232} \mathrm{U}$. However, even these prior HTGRs were fueled with ${ }^{235} \mathrm{U}$ and not ${ }^{233} \mathrm{U}$. Future HTGRs, as presently planned, will use only ${ }^{235} \mathrm{U}$. (More information on future HTGRs is given in Sect. 3.5.)

Most of the information in this chapter was taken from Sect. 4, Non-LWR Spent Fuel, of the Characteristics Data Base of Potential Repository Wastes. ${ }^{1}$ This data base drew heavily on data provided by the General Atomic Corporation, ${ }^{2}$ the designers of the FSV reactor. Packaging and criticality aspects of FSV (and other non-LWR) spent fuel have been reported elsewhere. ${ }^{3}$ 


\subsection{FORT ST. VRAIN FUEL}

The FSV HT'UR operated from 1979 to 1989. It had a rated power of $842 \mathrm{MW}(\mathrm{t})$, but ran well below that rating for much of its lifetime. The reactor had low availability, which was primarily due to the many operating problems associated with the water bearings of the helium circulator, resulting in frequent water ingress into the primary circuit. A secondary reason for the low availability was the core oscillation problem that limited the core power to approximately $80 \%$ of design power. The core oscillation problem was eventually solved. The core was made up of 1482 hexagonal fuel elements stacked in 6 layers. The initial core contained $774 \mathrm{~kg}$ of $U$ at $93.5 \%$ enrichment and $15,905 \mathrm{~kg}$ of thorium (Th). The fuel elements are surrounded by replaceable hexagonal reflector elements, around which are reflector blocks and reflector spacers that are all made of graphite.

\subsubsection{Physical and Chemical Description of Fort St. Vrain Fucl}

An FSV fuel element consists of a 280-lb hexagonal graphite block, 14.2-in. across the flats and 31.2-in. high. Each graphite fuel hlock (Fig. 3.1) contains 108 coolant channels and 210 fuel holes, all drilled from the top face of the element. The coolant holes extend through the element; the fucl holes extend to within about $0.3 \mathrm{in}$. of the bottom face. The fuel holes occupy alternating positions with the coolant channels in a triangular array within the element structure and contain the nuclear fuel. After the fuel is inserted in a fuel hole, the hole is sealed with a graphite plug ecmented into place. The fuel itself is in the form of carbide particles coated with layers of pyrolytic carbon and silicon carbide ( $\mathrm{SiC})$, bonded together into fuel rods by a carbonaceous matrix material. The fuel bed contains a homogeneous mixture of two types of particles, called fissile and fertile. Fissile particles contain thorium and $93.5 \%$ enriched uranium; fertile particles contain only thorium. The important parameters of fuel particles are as listed below:

Parameter

Th/U (atomic ratio)

Particle composition

Average fuel particle diameter, $\mu \mathrm{m}$

Average total coating thickness, $\mu \mathrm{m}$
Fissile

4.25

$(\mathrm{Th} / \mathrm{U}) \mathrm{C}_{2}$

200

130
Fertile

Th only

$\mathrm{ThC}_{2}$

450

140 


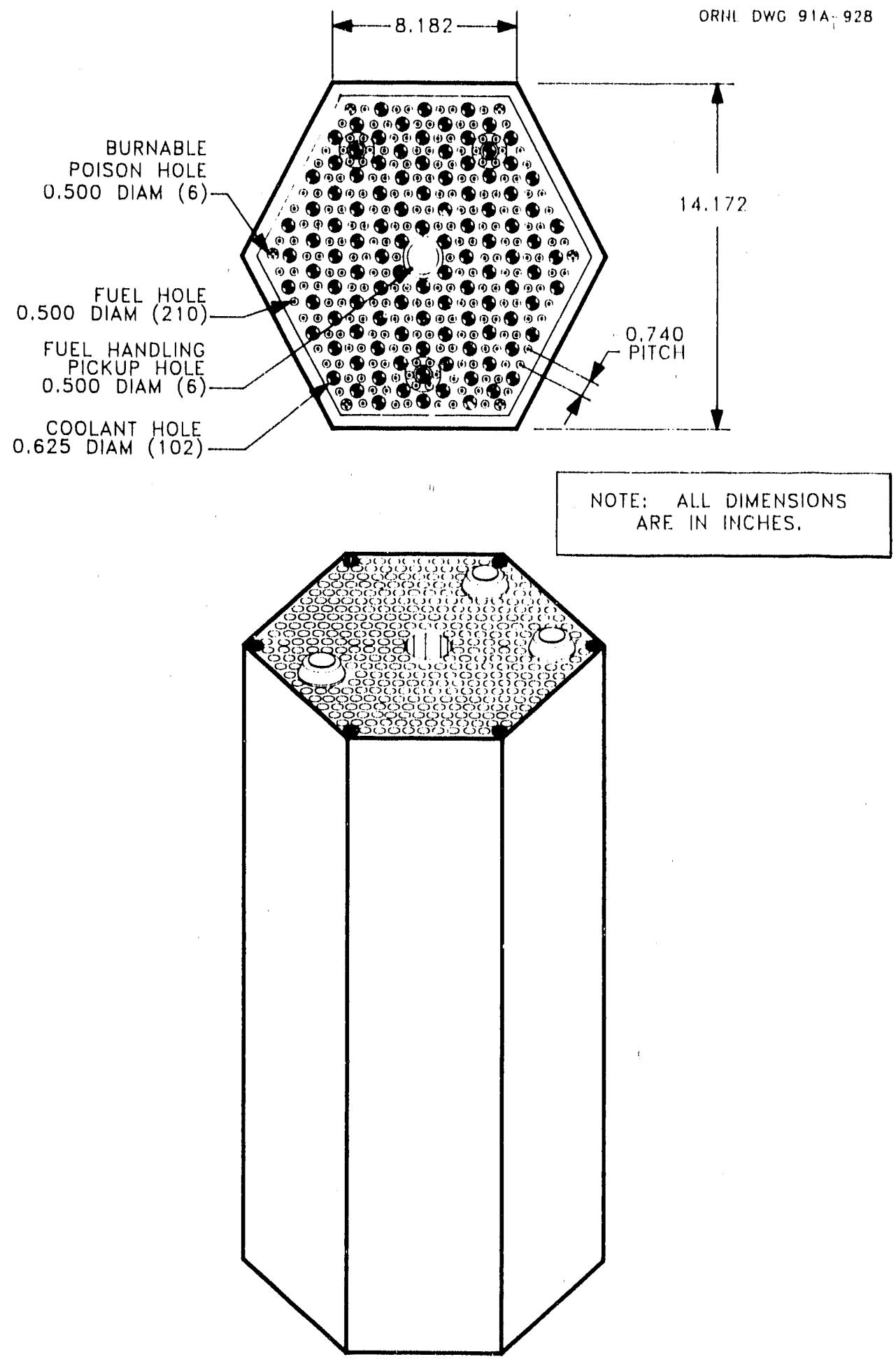

Fig. 3.1. FSV standard fuel element. 
The irradiated fuel contains the initial components plus fisssion products, ${ }^{233} \mathrm{U}$ bred from ${ }^{232} \mathrm{Th}$, other uranium isotopes, and a small quantity of plutonium and higher actinides. In the fertile particles, the fissile material is bred ${ }^{233} \mathrm{U}$, while the fissile particles contain both residual ${ }^{235} \mathrm{U}$ and bred ${ }^{233} \mathrm{U}$ as fissile material.

The graphite blocks were machined from needle-coke graphite supplied hy Great Lakes Carbon Company. Two types were used: H-327 in the initial core and H-451 in some test elements and replacement segments. These are high-quality isotropic graphites composed of relatively' small crystallites. These graphites have been well-characterized. The H-451type graphite will probably be used in future HTGRs. Although past feedstocks used to make H-451 may be in limited supply, H-451 quality graphite can be made from available petroleum feedstocks. Recently, the Japanese have introduced a graphite, designated IG-110, that might be considered for future HTGRs. It is a very high-grade, high-purity, small-crystallite graphite with superior dimensional and isotropic properties. IG-110 graphite is similar to Stackpole 2020 graphite made in the U.S. Both types of graphites are more expensive than the H-451-type graphite.

The fuel particles consist of spherical kernels of $\mathrm{ThC}_{2}$ (fertile particles, TRISO-coated) and $(\mathrm{Th}, \mathrm{U}) \mathrm{C}_{2}$ (fissile particles, TRISO-coated). These particles are coated, via a fluidized-bed, vapor-phase deposition process, with three fission-product-retaining layers of isotropic carbon; hence the name TRISO-coated (Fig. 3.2). The inner and outer layers are pyrolytic graphite, and the middle layer is $\mathrm{SiC}$ and is under compression from the outer graphite layer. There is a fourth layer called the "buffer," of porous carbon, next to the kernel of the fissile particles, to provide a volume for accumulation of fission product gases. Thus, each particle is a miniature pressure vessel of optimum geometry, designed to maintain its integrity during and after irradiation and during reprocessing until deliberately crushed. The SiC layer is highly resistant to both oxidation and moisture, even at extremely high temperatures.

The fuel cycle, as originally planned, included recycle of the fertile particles; thus, the size difference to allow separation of fissile and fertile particles by physical means. The original intent was that fissile particles would be taken to a high burnup and discarded intact (or 


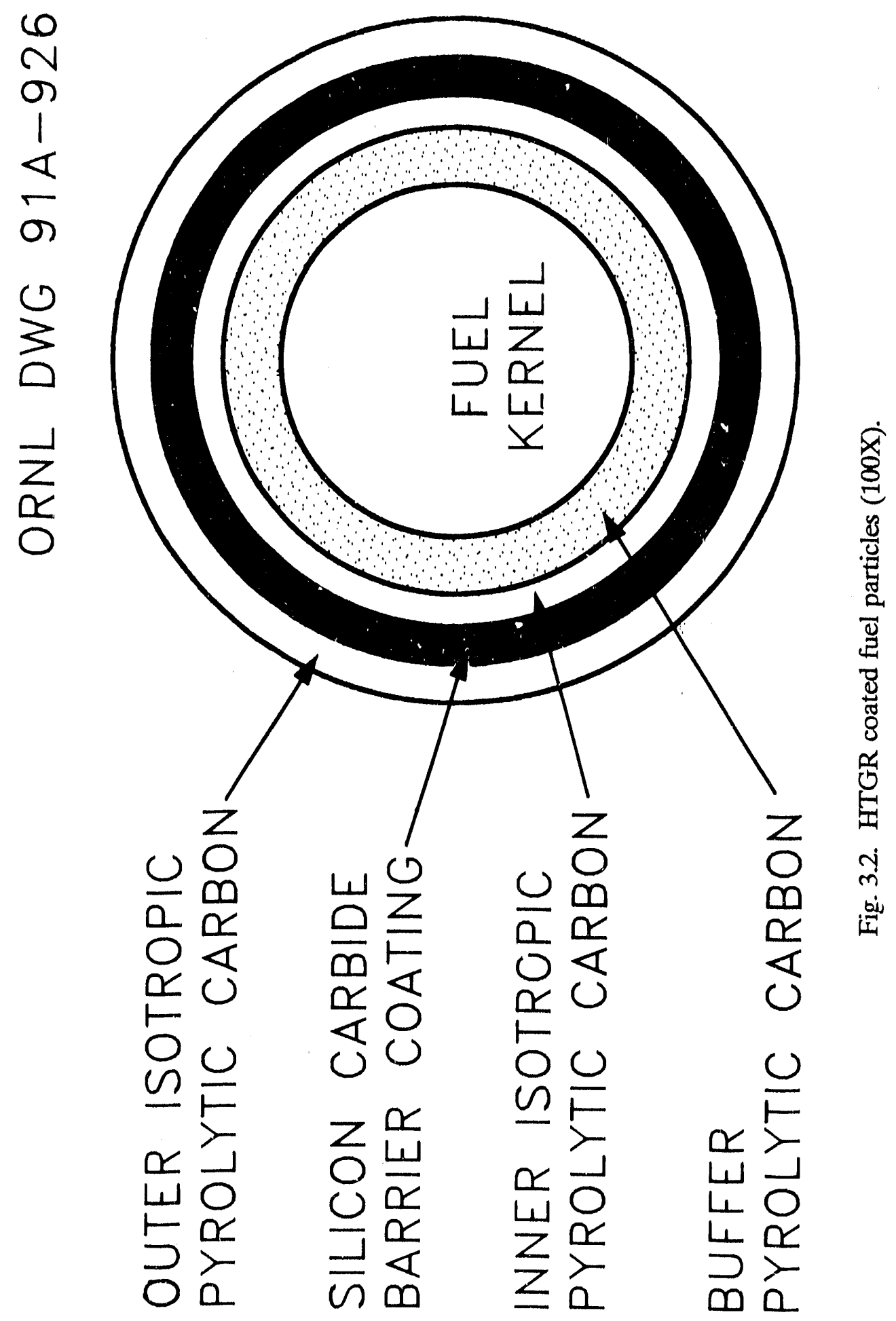


possibly reprocessed for one or two recycles, until the ${ }^{236} \mathrm{U}$ built up to an excessive level), while the fertile particles would be reprocessed and the ${ }^{233} \mathrm{U}$ separated chemically from the thorium (and fission products) and then refabricated into recycle fissile particles. Existing FSV fuel used only ${ }^{235} \mathrm{U}$ in the fissile particles because there was no recycled ${ }^{233} \mathrm{U}$ available (nor was there a remote refabrication facility, which is required for ${ }^{233} \mathrm{U}$ ).

Fertile and fissile particles are blended and then molded into fuel rods $0.5 \mathrm{in}$. in diam and 2.0-in. long. A carbonaceous binder is used to form "green" rods that are subsequently carbonized by firing at a high temperature prior 10 insertion in the graphite blocks. A fulllength fuel hole contains 15 fuel rods. In cases where fuel rods are carbonized in the graphite block, bonding of the fuel rods to the graphite may occur. However, for the FSV core, carbonizing the fuel rods was performed prior to placing the rods in the fuel block, and it was found that little bonding occurred between the rods and the graphite block during service in the reactor. As a result, fucl rods could be removed with minimal damage by "pushing" the rods out of the element after top and bottom plugs were removed or cut out.

Selected elements have fuel holes that also contain burnable poison. These burnable poison sticks consist of boron carbide particles, bonded together in a carbonaceous matrix analogous to the fuel rods.

The physical condition of the first three FSV discharge segments was determined by a nondestructive examination of various fuel elements after each set of elements was removed from the core. Nearly all of the elements had shrunk slightly in both axial and radial dimensions. However, the inspected elements were generally in good condition. Minor cracks, chips, and scratches were observed on some elements. Based on other tests, it is expected that 0.3 to $0.5 \%$ of the coatings in the elements discharged from the first three reloads may have failed. On later discharges, the failure rate is expected to be an order-ofmagnitude lower. Nearly identical fuel particles from the AVR have measured failure rates lower than 0.00$) 8 \% .^{4}$ 


\subsubsection{Quantities of Fort St. Vrain Fucl}

Table 3.1 summarizes the discharge history of the FSV reactor, which has been shut down since August 1989. Prior to that, there were three refuelings of one segment each. Each segment is about one-sixth of the core. The complete core consists of 1482 fuel blocks. The refueling segments are not all the same size, and there were also some test elements that were removed at the time of the first reload. There are also solid graphite reflector biocks, both axially and radially. However, some reflector blocks contain boronated steel and nickelbased alloy canisters containing boronated graphite, and these will need to be disposed as whole blocks or processed prior to disposal. Disposition of these reflector blocks will probably be as $\mathrm{LLW}$ with ${ }^{14} \mathrm{C}$ as the principal radioactive contaminant.

The first 726 fuel blocks that were discharged are stored in a special convection-cooled facility built for that purpose at the Idaho Chemical Processing Plant (ICPP). At one time, it was planned to build an HTGR reprocessing pilot plant in Idaho, and FSV spent fuel would have been the feedstock. There is still unused storage space at the ICPP facility but, in 1988, the governor of Idaho blocked any further receipts of FSV fuel. This issue is now the subject of litigation. As this report went to press, the U.S. Court of Appeals in San Francisco had decided to allow the shipment of fuel to Idaho.

The FSV spent fuel elements currently stored at ICPP are in 0.25-in. thick carbon-steel canisters with a diameter of $18 \mathrm{in.}$ and a length of $11 \mathrm{ft}$. They have ungasketed lids that are held in place by remotely operable clamps. Each canister contains four FSV elements. The current inventory of 726 elements thus requires 182 canisters. Information on the serial numbers of the elements and the canister numbers in which they are contained is available from the Idaho National Engineering Laboratory (INEL), which operates the ICPP.

If the final full-core discharge is also placed in canisters the size of those used at the ICPP, an additional 371 canisters will be required. As indicated elsewhere in this report, final repository disposal of intact blocks would require far fewer repository canisters if the blocks were stacked three or seven to a layer, or more than four layers high. The present canister 
Table 3.1. Historical and projected spent fuel discharged from the FSV HTGR ${ }^{\mathrm{a}}$

\begin{tabular}{cccccc}
\hline \multirow{2}{*}{$\begin{array}{c}\text { End of } \\
\text { calendar } \\
\text { year }\end{array}$} & $\begin{array}{c}\text { Number of fucl assemblies } \\
\text { dischargec }\end{array}$ & & \multicolumn{2}{c}{$\begin{array}{c}\text { Mass of fuel discharged } \\
\text { (MTIHM) }\end{array}$} \\
\cline { 2 - 3 } \cline { 5 - 6 } \cline { 5 - 6 } & Annual & Cumulative & & Annual & Cumulative \\
\hline 1979 & $246^{\mathrm{b}}$ & 246 & & 2.80 & 2.80 \\
1980 & 0 & 246 & & 0.00 & 2.80 \\
1981 & 240 & 486 & & 2.77 & 5.57 \\
1982 & 0 & 486 & & 0.00 & 5.57 \\
1983 & 0 & 486 & & 0.00 & 5.57 \\
1984 & 240 & 726 & & 2.85 & 8.42 \\
1985 & 0 & 726 & & 0.00 & 8.42 \\
1986 & 0 & 726 & & 0.00 & 8.42 \\
1987 & 0 & 726 & & 0.00 & 8.42 \\
1988 & 0 & $726^{c}$ & & 0.00 & 8.42 \\
1989 & $126^{\mathrm{d}}$ & 852 & & 1.32 & 9.74 \\
1990 & $615^{\mathrm{d}, \mathrm{e}}$ & 1,467 & & 6.47 & 16.21 \\
1991 & $741^{\mathrm{f}}$ & 2,208 & & 7.49 & 24.00 \\
\hline
\end{tabular}

${ }^{\mathrm{a}}$ From DOE/RW-0006, Rev. 6, p. 34 (October 1990).

'This refueling replaced 246 spent fuel elements made up of 240 standard fuel clements and 6 fuel test elements.

'All spent fuel discharged prior to December 31,1988 , is located at the Idaho Chemical Processing Plant (ICPP).

${ }^{d}$ Fuel removed from the core in 1989 and 1990 remains on-site in temporary storage wells until shipment to the ICPP can be accomplished or an independent spent fuel storage installation is built at Fort St. Vrain.

'1990: 330 fuel blocks have been removed from the core prior to February 28, 1990.

It is expected that the entire core will be defueled by the end of 1991. 
size used at the ICPP is smaller than that planned tor vitrified HLW ( 24 in. by $10 \mathrm{ft}$ ) or for LWR spent fuel (26 in. by $15.6 \mathrm{ft}$ ). Stacking FSV blocks three to a layer requires a 36-in. diam cask, while seven to a layer requires a 47 -in. diam cask.

\subsubsection{Radiological Properties of Fort St. Vrain Fuel}

The radioactive nuclide composition has been calculated for irradiated H'TGR fuel, assuming a burnup of 100,000 MW/MTIHM, and is summarized in Table 3.2 for three time periods: 10 years, 100 years, and 1000 years after discharge. A detailed listing is given in Appendix A, along with other decay times. The maximum burnup actually achieved at FSV is 52,000 $\mathrm{MWd} / \mathrm{MTIHM}$, and the average value is in the range of 30,000 to $35,000 \mathrm{MWd} / \mathrm{MTIHM}$.

Table 3.2. Quantities of radioactive nuclides in HTGR fuel

Nuclide quantity (Ci/MTIHM)

\begin{tabular}{lrrr} 
& \multicolumn{3}{c}{ Nuclide quantity (Ci/MTIHM) } \\
& $\begin{array}{c}10 \text { years } \\
\text { after discharge }\end{array}$ & $\begin{array}{c}100 \text { years } \\
\text { after discharge }\end{array}$ & $\begin{array}{c}1,000 \text { years } \\
\text { after discharge }\end{array}$ \\
\hline Actinides (and daughters) & 14,500 & 5,800 & 4,400 \\
Fission products & 967,000 & 111,000 & 3 \\
Carbon-14 & 20 & 20 & 18 \\
Tritium & 80 & $<1$ & $\sim 0$ \\
\hline
\end{tabular}

The production of the activation products ${ }^{14} \mathrm{C}$ and tritium is of potential concern for some disposal and reprocessing scenarios and is explained further.

Carbon-14. There are two major neutron-induced reactions that produce ${ }^{14} \mathrm{C}$ in an HTGR:

$$
\begin{aligned}
& { }^{14} \mathrm{~N}(\mathrm{n}, \mathrm{p}){ }^{14} \mathrm{C} \\
& { }^{13} \mathrm{C} \text { (n,gamma) }{ }^{14} \mathrm{C}
\end{aligned}
$$


Nitrogen is contained in the fuel element in small quantities due to its processing history. The nitrogen is present either in adsorbed form in the graphite material, as chemically bound, or as elemental nitrogen entrapped in voids in the fuel element material. The nitrogen that serves as the precursor for ${ }^{14} \mathrm{C}$ generation is the residual nitrogen remaining in the fual element alter loosely bound nitrogen has been desorbed into the coolant circuit and gettered in the coolant cleanup circuit. ${ }^{13} \mathrm{C}$ occurs naturally in all carbon material with an abundance of $1.11 \%$.

A careful study of ${ }^{14} \mathrm{C}$ production in HTGRs was performed by Davis. ${ }^{5}$ The results of this study have been abstracted from Davis' work and are shown in Table 3.3. The nitrogen impurity was assumed to be at a level of $30 \mathrm{ppm}$ in the graphite and was calculated to be the source of more than $75 \%$ of the ${ }^{14} \mathrm{C}$. The presence of ${ }^{13} \mathrm{C}$, primarily in the fuel block, accounted for most of the remainder ${ }^{14} \mathrm{C}$ production.

Measured values of nitrogen in HTGR fuel assemblies have been reported, ${ }^{6}$ and typically range from $6-12 \mathrm{ppm}$, thus implying that actual overall ${ }^{14} \mathrm{C}$ levels may be lower by a factor of two to five. Snider and Kaye ${ }^{7}$ assumed a nitrogen impurity value of $10 \mathrm{ppm}$ and otherwise obtained results that are comparable and scalable to the results cited in Table 3.3.

The NRC LLW regulations, stated in 10 CFR 61, place an upper limit on the volumetric level of ${ }^{14} \mathrm{C}$ in Class $\mathrm{C}$ LLW at $8 \mathrm{Ci} / \mathrm{m}^{3}$. The ${ }^{14} \mathrm{C}$ quantities shown in Table 3.3 for the graphite block are equivalent to a value of approximately $3 \mathrm{Ci} / \mathrm{m}^{3}$. Thus, if the graphite block were physically separated from the fuel, and was uncontaminated (or subsequently decontaminated) of actinides and fission products, it would be permissible, by current regulations, to dispose of the graphite block as Class C LLW.

The calculations in Table 3.3 assumed a fuel burnup of 100,000 MWd/MT (metric tons). However, all FSV fucl experience lower burnups, typically less than $35,000 \mathrm{MWd} / \mathrm{MT}$. It should be noted that graphite blocks exposed to less than $25,000 \mathrm{MWd} / \mathrm{MT}$ burnups have the potential to qualify as Class A LLW, although the fission product contamination limits are more stringent than Class C LLW levels by a factor of ten. 
Table 3.3. Production of ${ }^{14} \mathrm{C}$ in graphite and fuel of $\mathrm{HT} \mathrm{JRs}$

\begin{tabular}{|c|c|c|c|c|}
\hline & $\begin{array}{l}\text { Graphite } \\
\text { in } \\
\text { fuel } \\
\text { block }\end{array}$ & $\begin{array}{l}\text { Graphite } \\
\text { in } \\
\text { reflector } \\
\text { blocks }\end{array}$ & $\begin{array}{c}\text { Fuel } \\
\left(\mathrm{UC}_{2}+\mathrm{ThC}_{2}\right)\end{array}$ & Total \\
\hline $\begin{array}{l}\text { Impurity content: } \\
\text { lvitrogen (ppm) }\end{array}$ & 30 & 30 & $25^{\mathrm{b}}$ & \\
\hline $\begin{array}{l}\text { Material in core } \\
(\mathrm{MT} / \mathrm{MTIHM})\end{array}$ & 10.93 & 1.77 & 1.0 & \\
\hline $\begin{array}{l}\text { Quantity of eleme } \\
\text { (g/MTIHM) } \\
\text { Carbon } \\
\text { Nitrogen }\end{array}$ & $\begin{array}{l}1.093 \times 10^{7} \\
3.28 \times 10^{2}\end{array}$ & $\begin{array}{l}1.77 \times 10^{6} \\
3.54 \times 10^{1}\end{array}$ & $\begin{array}{l}0.0906 \\
2.50 \times 10^{1}\end{array}$ & \\
\hline $\begin{array}{l}{ }^{14} \mathrm{C} \text { at } 160 \mathrm{~d} \text { after } \\
\text { of fuel }(\mathrm{Ci} / \mathrm{MTIH}) \\
\text { Carbon } \\
\text { Nitrogen }\end{array}$ & $\begin{array}{r}3.69 \\
12.58\end{array}$ & $\begin{array}{l}<0.60 \\
<2.04\end{array}$ & 0.959 & \\
\hline $\begin{array}{l}\text { Total }{ }^{14} \mathrm{C}: \\
(\mathrm{Ci} / \mathrm{MTIHM})\end{array}$ & 16.27 & $<2.63$ & 1.167 & $<19.9$ \\
\hline
\end{tabular}

aThese results are from ref. 5 .

bAssumed to be the same as LWR fuels. 
Tritium. The reported level of tritium results from the reaction

$$
{ }^{6} \mathrm{Li}(\mathrm{n}, \mathrm{alpha}){ }^{3} \mathrm{H} \text {. }
$$

Lithium is believed to be present in the graphite block at an impurity level oi only 0.005 ppm, but tritium production is still calculated to be nontrivial due to the relatively high neutron cross-section for this reaction. Tritium has a half-life of 12.3 years and, thus, is not a factor in long-term radiological considerations. The calculated value of $80 \mathrm{Ci} / \mathrm{MTIHM}$ for HTGR fuel at a burnup of $100,000 \mathrm{MWd} / \mathrm{MTIHM}^{8}$ translates, for the graphite block, into a tritium value of approximately $15 \mathrm{Ci} / \mathrm{m}^{3}$. This is well below the tritium limit for Class $\mathrm{A}$ LLW of $40 \mathrm{Ci} / \mathrm{m}^{3}$. Thus, the presence of tritium as an activation product should not constrain the choice of disposal options.

\subsection{PEACH BO'TIOM-1 REACTOR FUEL}

The Peach Bottom-1 HTGR operated from 1966 to 1974. It was rated at $115 \mathrm{MW}(\mathrm{t})$. It utilized a 12-ft-long cylindrical fucl element $3.5 \mathrm{in}$. in diam composed largely of graphite, containing about $1.8 \mathrm{~kg}$ of uranium and thorium (Fig 3.3). These heavy metals were present as carbon-coated particles that were formed into compacts by addition and sintering of carbonaceous materials. The heavy-metal loading in this reactor, about $1.4 \mathrm{MT}$, was contained in 804 elements. The design burnup for this fuel was $\sim 73,000) \mathrm{MWd} / \mathrm{MTIHM}$. However, excessive fuel failures that occurred during operation of Core 1 resulted in removal of that core at about half the design burnup. The fuel failure was attributed to the fuel particle coating system, which consisted of a single pyrocarbon coating with no buffer layer. This system was modified for the second core to a two-layer system including a buffer layer (termed BISO coating) that performed satisfactorily and reached design burnup. The reactor was shut down at this point.

Most of the fuel from both cores is now located at INEL in 46 24-in.-diam baskets (Core 1) and 44 18-in.-diam baskets (Core 2). A small quantity (10 elements) is located at Oak Ridge National Laboratory (ORNL). The uranium and thorium within the fuel compacts are in the form of earbides uniformly dispersed as coated particles in the graphite matrix. 


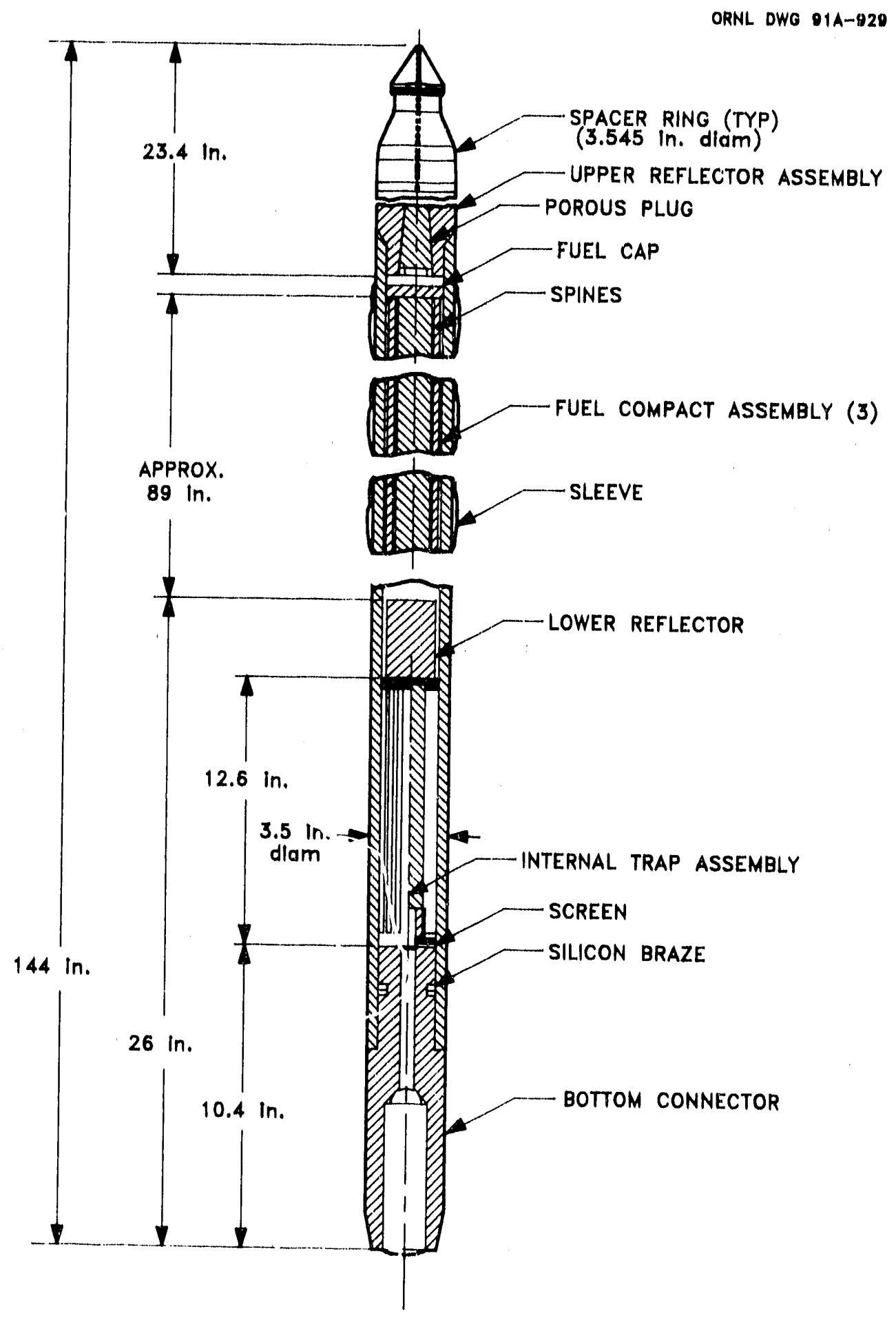

Fig. 3.3. Peach Bottom Unit 1, core 1 fuel element. 
For Core 1, the particle coating is monolithic, laminar, pyrolytic carbon obtained by sintering at $1800^{\circ} \mathrm{C}$. The coated particles are between 210 and $595 \mu \mathrm{m}$ in diam, with coating thicknesses of $55 \pm 10 \mu \mathrm{m}$.

The Core 2 fuel elements are essentially the same as the Core 1 elements. The major design difference is in the coated particles. The coating of the Core 2 fuel and fertile particles consisted of an inner, low-density buffer carbon coating surrounded by an outer isotropic layer of pyrolytic carbon. The total coating thickness was between 90 and $130 \mu \mathrm{m}$. The coated pa ticles were $\sim 340$ and $630 \mu \mathrm{m}$ in diam, respectively, for the fissile and fertile particles.

\subsection{COMPARISON TO OTHER NON-STANDARD FUELS}

In the context of HLW disposal, HTGR fuel is part of a larger category of non-standard fuels that must be accepted by the repository. This category of non-standard fucls includes: ${ }^{3}$

1. Special LWR fuels, specifically

a. those covered under the DOE/utility contract, which inciudes several categories, one of which is Category F-2 (identified as leakers);

b. massively failed fuel, of which ine TMI-2 core is our only example; and

c. miscellaneous LWR fuels left ov ar from various test and hot cell examination projects, most of which are stored at INEL or Savannah River Laboratory (SRL).

2. HTGR fuels.

3. Other non-LWR spent fuels, such as educational and research reactor fuels and test reactor fuels, such as TRIGA, PULSTAR, and the Shippingport LWBR.

All three of these classes of LWR spent fucls include (or consist of) potentially troublesome waste forms, and the $10^{-5}$ fraction per year release limit exacerbates this problem. For example, LWR leakers may require special packaging, and the TMI-2 core and miscellaneous LWR fuels will almost certainly require special packaging. In addition, non-LWR spent 
fuels, which include motals, carbides, hydrides, and other semi-exotic forms, will also require special packaging if they cannot be processed.

The "special packaging" alluded to in the preceding paragraph has not yet been designed. For that matter, the necessary canister containment specifications have yet to be defined. However, it seems clear that, in the absence of reprocessing capabilities (which would convert spent fuels to vitrified HLW), special packaging will have to be the answer to disposal requirements. It is not unreasonable to believe that such packaging can be designed and constructed.

Table 3.4 is an abbreviated summary listing of all the non-LWR and special LWR fuels (except leakers), all of which may requirc special packaging. This list was taken from a study that made basic assumptions regarding criticality and chemical reactivity and then estimated the number of canisters that would be required for repository disposal. ${ }^{3}$ Two sizes of canisters were assumed in that study: $24 \mathrm{in}$. by $12 \mathrm{ft}$ and $28 \mathrm{in}$. by $15 \mathrm{ft}$. A total of 952 to 1392 canisters was estimated, of which 554 are for FSV fuel and 138 are for Peach Bottom-1 fuel. For comparison, it is projected that there may be 15,000 canisters of vitrified HLW and 45,000 canisters of LWR spent fuel by 2020. The FSV estimate was based on four blocks per canister. For larger canisters, proportionately lewer would be required. For a "3 by 6 " canister, (i.e., six layers of three blocks cach), 31 canisters would hold all the FSV fuel.

The thermal output of 5-year old FSV fuel packaged 18 blocks per eanister would be about $450 \mathrm{~W}$. This is far less than that for LWR fucl, for which the upper limit is about ten times higher. FSV thermal output is in the same range as vitrified HLW, estimated at 300 to $800 \mathrm{~W}$ per canister.

\subsection{FUTURE HTGRS}

Future HTGRs will be based on ${ }^{235} \mathrm{U}$ fuel. The accompanying ${ }^{238} \mathrm{U}$ will be the source of ${ }^{239} \mathrm{Pu}$ (as in LWRs), which adds to the in situ fissile content. For commercial power HTGRs, the enrichment will probably be no higher than $20 \%$ in response to nonproliferation 
Table 3.4. Estimated number of canisters required for repository disposal of various non-LWR and special LWR spent fuels

\begin{tabular}{|c|c|c|c|}
\hline & $\begin{array}{l}\text { Total number of } \\
\text { fuel assemblies } \\
\text { as of } 2020\end{array}$ & $\begin{array}{c}\text { Estimated fuel } \\
\text { assemblies } \\
\text { per canister }\end{array}$ & $\begin{array}{c}\text { Estimated } \\
\text { number of } \\
\text { canisters } \\
\text { required }\end{array}$ \\
\hline \multicolumn{4}{|l|}{ 24-in. diam $\times 12-\mathrm{ft}$ canisters } \\
\hline Fort St. Vrain & 2214 & 4 & 554 \\
\hline Peach Bottom-1 & 1639 & 12 & 138 \\
\hline $\begin{array}{l}\text { Special LWR \& other } \\
\text { non-LWR fuels }\end{array}$ & 6141 & 12 to 112 & 200 \\
\hline $\begin{array}{c}\text { 28-in. diam } \times 15-\mathrm{ft} \text { canisters } \\
\text { Special LWR } \& \text { other } \\
\text { non-LWR fuels }\end{array}$ & 500 & 1 to 8 & 60 to 500 \\
\hline
\end{tabular}


constraints. This also allows extensive generation of ${ }^{239} \mathrm{Pu}$, which is more beneficial in HTGRs than in LWRs.

A defense production HTGR will probably use at least some highly enriched ${ }^{235} U$ to compensate for the presence of lithium target material, which acts as a neutron poison. If plutonium production is also an objective, lower ${ }^{235} \mathrm{U}$ enrichment or depleted uranium blankets will be needed.

Based on studies conducted after the FSV fuel composition was defined, ${ }^{9}$ future HTGR fuel will use a mixture of $15 \%$ carbide and $85 \%$ oxide in the fissile particles. This composition gives improved fuel performance. The proved TRISO coating (over a buffer layer) will be used for future fuel. In this country, the prismatic block design will be used.

Several conceptual design studies are currently underway for both a modular commercial power HTGR and a defense production HTGR. These new designs will undoubtedly incorporate changes from the FSV design, but the basic fuel design will still be based on TRISO-coated fuel particles contained in a hexagonal graphite block.

\subsection{REFERENCES}

1. U.S. Department of Energy, Characteristics of Spent Fuel, High-Level Waste, and Other Radioactive Wastes Which May Require Long-Term Isolation, DOE/RW-0184, Vols. 1-6, December 1987; Vols. 7-8, June 1988.

2. R. P. Morissette and N. Tomsio, Characterization of Fort St. Vrain Fuel, ORNL/SUB-86(122047/1, Martin Marictta Energy Systems, Inc., Oak Ridge National Laboratory, October 1986.

3. R. Salmon and K. J. Notz, Non-LWR and Special LWR Spent Fuels: Characteristics and Criticality Aspects of Packaging and Disposal, ORNL/TM-11016, Martin Marietta Energy Systems, Inc., Oak Ridge National Laboratory, January 1990. 
4. H. Nabielek and D. G. Martin, "Some Studies of the Failure of Irradiated Triso-Coated Fucl Particles During Their Anneal at High Temperatures," J. Nucl. Mat. 120, 345-48 (19834).

5. W. Davis, Jr., "Carbon-14 Production in Nuclear Reactors," Management of Low-Level Radioactive Wastes, Vol. 1, 151-191, ed. M. W. Carter, A. A. Moghissi, and B. Kahn, Pergamon Press (1979).

6. L. H. Brooks, et al., Carbon-14 in the HTGR Fuel Cycle, GA-A13174 (Nov. 1974).

7. J. W. Snider and S. V. Kaye, "Process Behavior and Environmental Assessment of C-14 Releases trom an HTGR Fuel Reprocessing Facility," Proceedings, ANS-AIChE Conference on Controlling Air-Borne Effluents from Fuel Cycle Plants (August 1976).

8. S. B. Ludwig, Oak Ridge National Laboratory, Oak Ridge, Tennessee, personal communications to G. E. Michacls.

9. F. J. Homan, et al., "Stoichiometric Effects on Performance of High-Temperature Gas-Cooled Reactor Fucls from the U-C-O System," Nucl. Technol. 35, 428-41 (September 1977). 


\section{OVERVIEW OF OPTIONS}

There are several possible options to put HTGR spent fuel into a form that will be acceptable for repository disposal. The preferred option depends on the waste acceptance criteria for the repository, availability of LLW disposal for graphite, overall economics, and overall risks. Frequently, the minimum processing that yiclds an acceptable waste form also gives the lowest costs as well as the simplest process and the least risk. The diagram in Fig. 4.1 shows the options that were considered in this study.

\subsection{WHOLE-BLOCK DISPOSAL}

Starting with an HTGR spent fuel element (Fig. 4.1), the first question is, Is whole block HTGR spent fucl disposal acceptable? If the answer is yes, the HTGR spent fuel can be disposed of in the repository after suitable packaging. This leads to the next question, Is overpack, coating or encapsulation required? The answer to this question determines if direct disposal of the HTGR spent fuel block is allowed. If direct disposal is acceptable, the spent fuel can be placed in waste canisters as is proposed for LWR spent fuel. Figure 4.2 shows the planned Yucca Mountain spent fuel waste canister for LWR spent fuel. Figure 4.3 shows a conceptual canister of similar dimensions for HTGR spent fuel and two larger canister sizes for HTGR spent luel. Repository waste canister size is limited by spent fuel decay heat load. If too much spent fuel is put into a canister, the waste or nearby rock will overheat. HTGR spent fuel has a lower decay heat load by volume of a factor of 5 to 10; therefore, larger, more economical waste packages might be an option for the direct spent fucl disposal scenario. The optimum canister size is determined by handling and economic considerations within the limits imposed by the heat load.

If direct disposal is not allowed, the option exists to "overpack, coat, or encapsulate" whole HTGR spent fuel blocks to improve the disposal performance of the waste before packaging. These two options for whole-block disposal are discussed in detail in Sect. 5. 


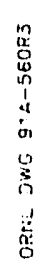

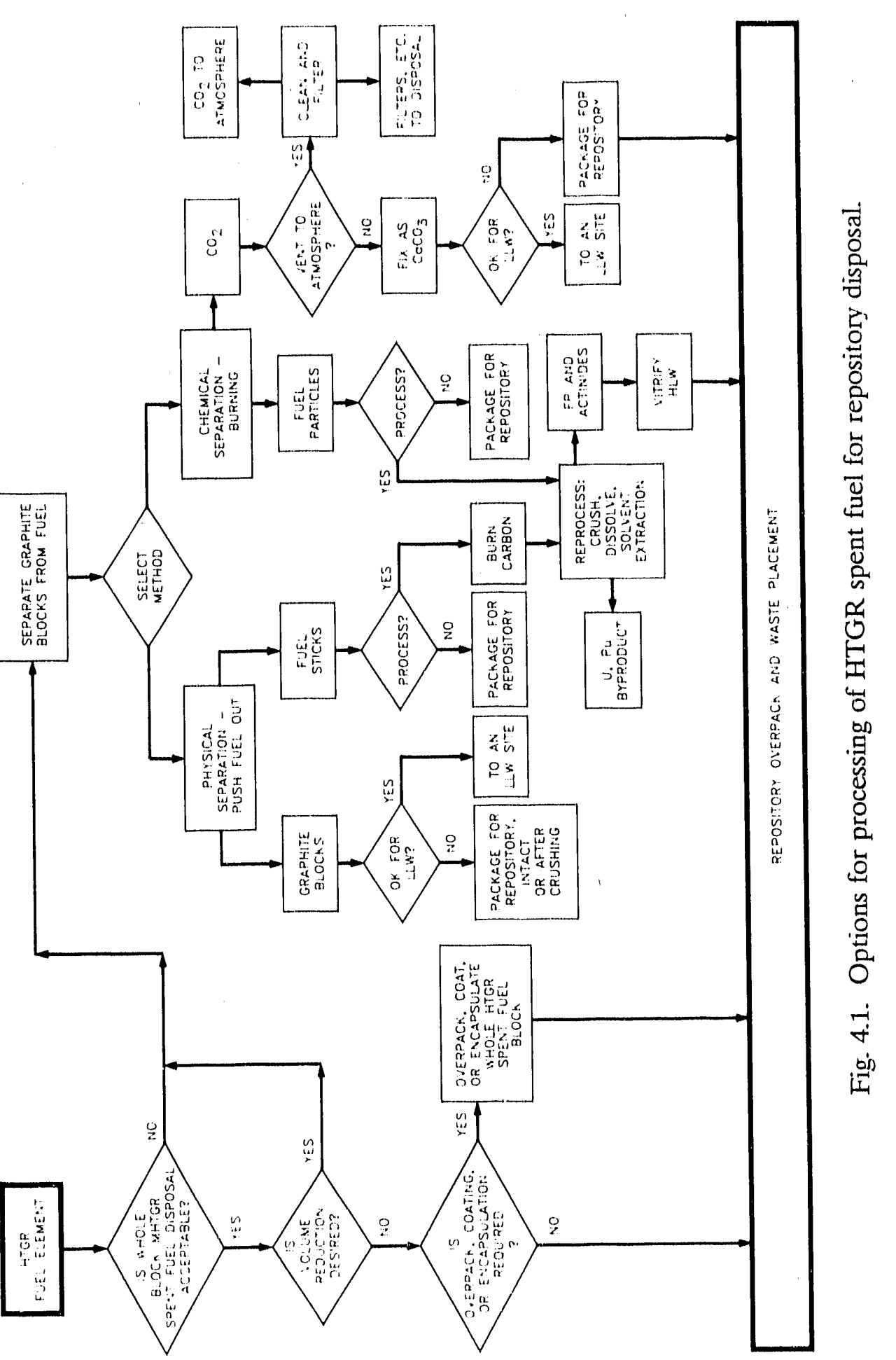

( 
ORNL. DWO $91 A-545$

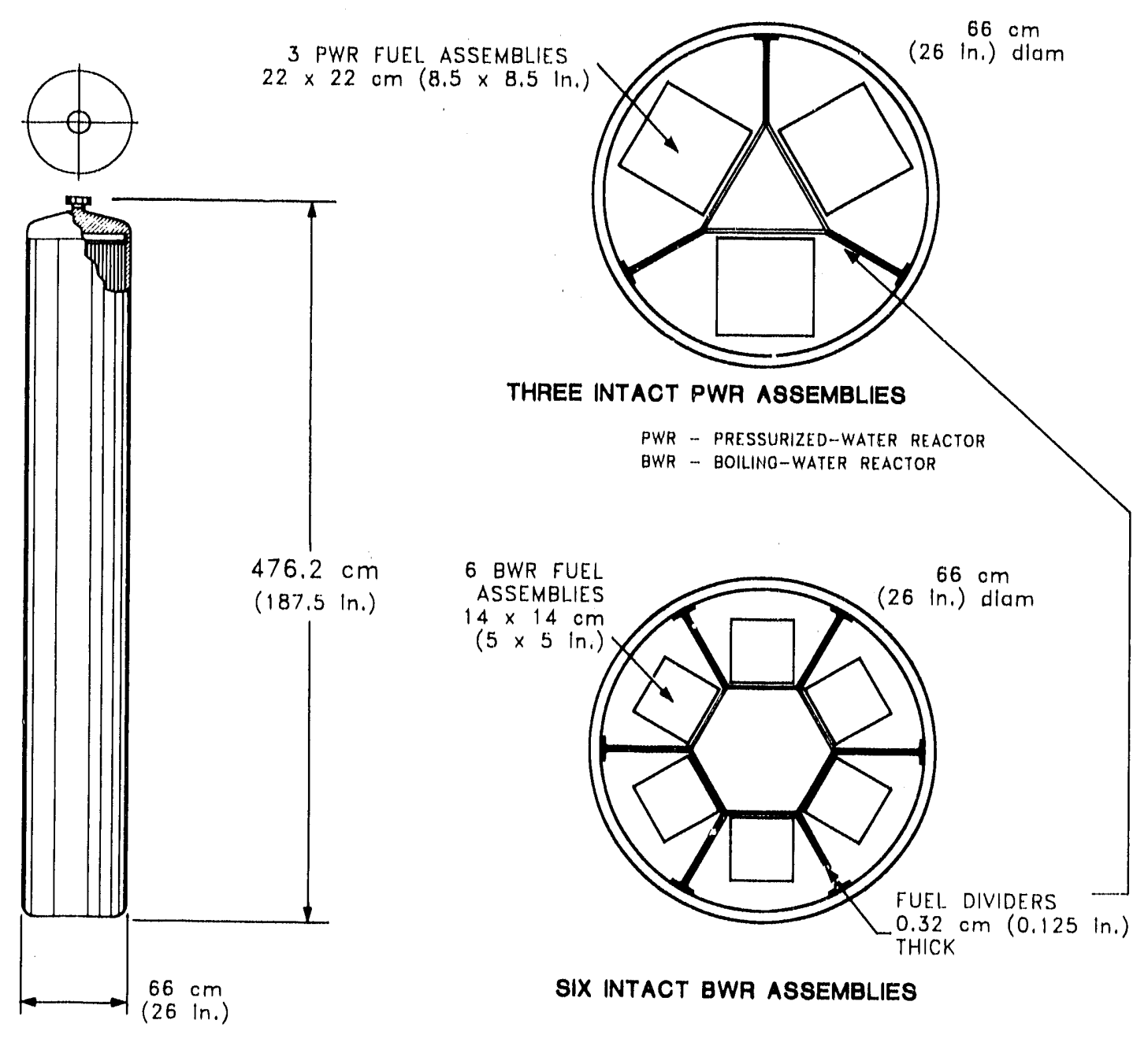

Fig. 4.2. United States Yucca Mountain project reference spent fuel container. 

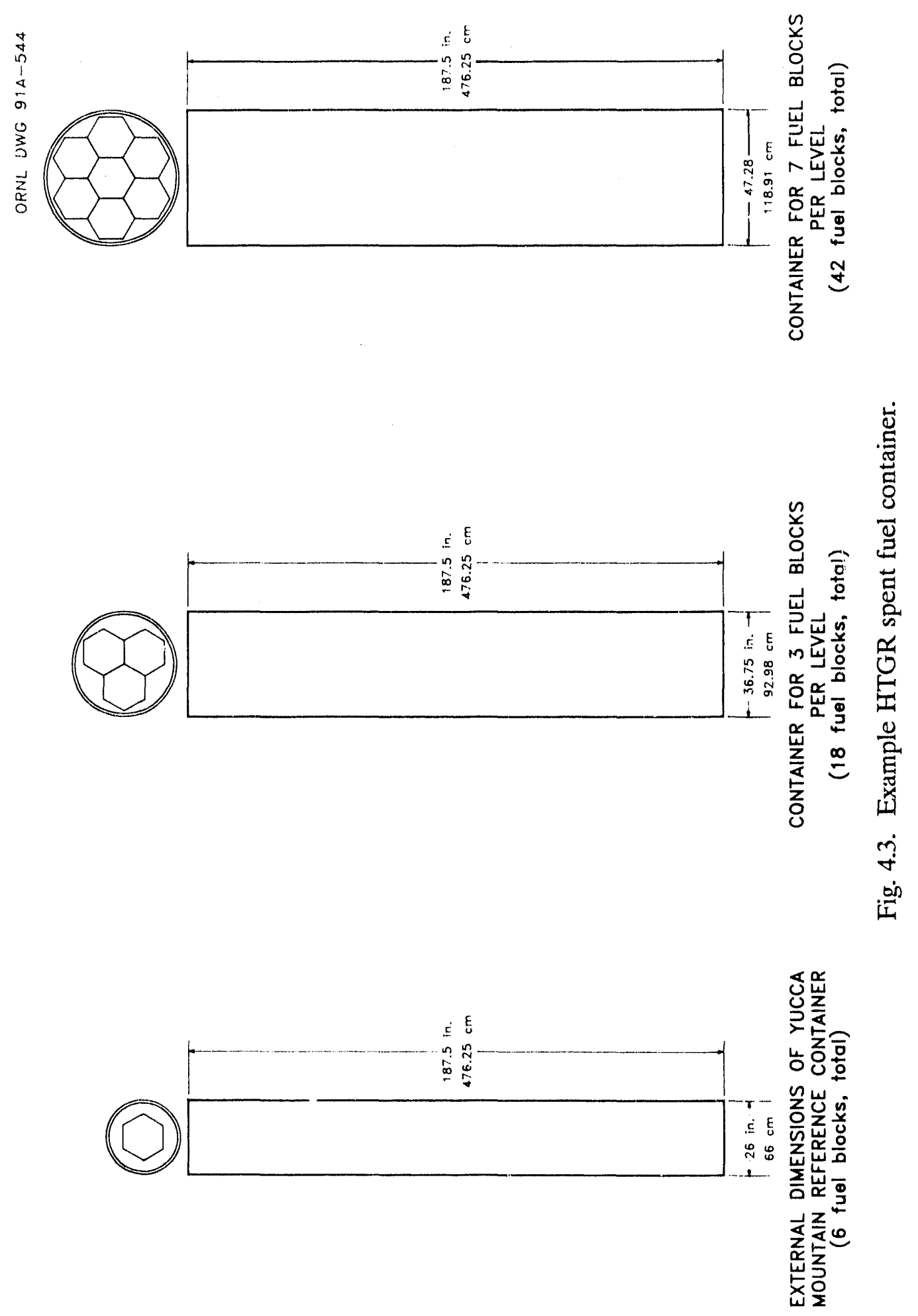


\subsection{DISPOSAL WITH PRIOR REMOVAL OF GRAPHITE}

If whole block spent fuel is unacceptable for repository emplacement, the first processing option is to separate the spent fuel assembly into (1) the spent fuel matrix material and (2) the carbon from the graphite block. In the specific case of FSV HTGR spent fuel, 56\% by volume of the intact assembly is graphite; the fuel rods occupy $24 \%$ of the overall volume, and the coolant holes take up the other $20 \%$. The separation process can be a physical or mechanical process that yields graphite wastes or a chemical process such as burning where the graphite is oxidized to carbon dioxide. After separation, spent fuel processing and carbon processing must be considered separately.

For disposal of spent fucl, several options are available that depend upon whether the fuel is in the form of fuel rods obtained by mechanical separation or coated particles obtained by burning. The simplest option is to package the fuel rods for disposal at the repository. The other option for mechanically separated fuel is to burn and chemically process the fuel rods to final products consisting of fissile-fertile byproduct and a suitable waste form for the fission products and actinides. If separation has been by burning the fuel element, the coated particles can be further processed to final products as in the case of the fuel rods above, or the particles can be packaged for disposal at the repository. Various overpack, coating, or encapsulation technologies can be considered to produce an acceptable waste form.

For carbon processing, there are two different materials $\left(\mathrm{CO}_{2}\right.$ or graphite) to be disposed depending on whether burning or mechanical separation has been used. Depending on the fuel design and performance and upon the separation process efficiency, some fission products could be associated with the carbon waste stream. If the fission product contamination is low enough, the carbon waste can be treated as LLW. (It has been assumed that release of $\mathrm{CO}_{2}$ to the environment is not an acceptable option although it is depicted on the option diagram.) If the carbon stream contains significant quantities of longlived radionuclides, it may be required to go to the HLW repository. 
If the carbon waste stream must go to the repository, it must meet certain minimum requirements. If the carbon is in the form of carbon dioxide, it can be reacted with calcium hydroxide or barium hydroxide to yicld stable calcium carbonate (limestone) or barium carbonate. A carbonate waste form going to a repository would be significantly different from spent fuel; in particular, its heat generation rate would be very low. This would allow the carbon waste form to be emplaced in suitable disposal facilities without the need for significant dispersion of heat. In contrast, typical spent fuel with its much higher decay heat is disposed of in small canisters to allow conduction of decay heat to the rock while not overheating the waste. These options are discussed in more detail in Sect. 6.

\subsection{DISPOSAL WITH DISSOLUTION OF SPENT FUEL}

The last option is chemical processing of the spent fuel matrix. This includes the option of conventional reprocessing with recovery of uranium, plutonium, and/or thorium. If the waste from reprocessing is converted into glass, as has been proposed for HTGR reprocessing plants, the waste should meet all aceeptance criteria. The repository is currently designed for glass waste forms from nuclear fuel reprocessing plants. Other waste forms must be evaluated on a case-by-case basis. This option is discussed in more detail in Sect. 7. 


\section{WHOLE BLOCK DISPOSAL}

\subsection{INTRODUCTION}

This section addresses two questions. The first is whether whole block HTGR spent fuel disposal in a repository can be expected to be acceptable. There are four complementary approaches that can address this issue: (1) previous studies and experiments, (2) comparison of characteristics of HTGR spent fuel with regulations, (3) comparison of characteristics of HTGR spent fuel with other wastes that are accepted by a repository, and (4) options for improved performance. These issues are discussed in Sect. 5.2.

The second question addressed in this section is the engineering and cost impact of HTGR spent fuel block disposal on the repository compared to other types of spent fuel per MTHM and its implications for repository capacity. Although this paper does not attempt to deal with all aspects of this concern, several strategies for emplacing HTGR fuel assemblies into canisters are addressed; and the number of canisters required for disposal of fuel from existing HTGRs is calculated and put into context. This issue is discussed in Sect. 5.3.

\subsection{ACCEPTABILITY OF WHOLE BLOCK DISPOSAL}

A preliminary assessment of whole block disposal in a repository is provided. This initial assessment is based on idealized calculations. Detailed assessments for direct disposal of HTGR spent fuel must also consider issues such as failed fuel and tramp contamination of fuel element exterior with uranium. These types of considerations apply to all fuel types.

\subsubsection{Previous Studies and Experiments}

The authors are unaware of any studies in the U.S. on the acceptability of direct disposal of HTGR spent fuel in a repository. There have been detailed studies in Germany ${ }^{1,2}$ of direct disposal of HTGR spent fuel in the planned German salt repository since the 1970s. These studies have concluded that this type of disposal is feasible, safe, and environmentally 
acceptable. Laboratory and hot cell experiments show the waste form has excellent performance under 300 bar, $1500^{\circ} \mathrm{C}$ salt brine conditions. In situ full-scale tests with spent HTGR fuel are to be initiated in late 1991 in the Asse Salt Mine. These tests, with real spent fuel and waste packages, are to demonstrate both spent fucl waste placement technology and repository performance. The spent fucl will be removed from the experimental salt mine upon completion of the experiment. The conditions in a salt repository are considerably different from those at the proposed repository at Yucca Mountain; thus, definitive conclusions about acceptability of HTGR spent fuel at Yucca Mountain cannot be made. The German data do, however, lend support to the feasibility of direct disposal at the proposed U.S. repository site. The planned German tests should demonstrate on a lull scale one set of equipment for waste placement that could be used in any repository.

Assuming that ongoing German studies repository demonstration tests confirm initial studies, there may be the option to dispose of U.S. HTGR spent fucl in Germany if the quantities are limited and thereby avoid the expense of qualifying the U.S. repository for disposal of HTGR spent fuel. Several years ago, Sweden exchanged a number of HLW canisters with glass waste for a number of diflicult-to-reprocess LWR spent fuel assemblies from Germany. The basis for exchange was as follows. Sweden is planning a repository for spent fuel, but had a small number of vitrified HLW canisters. Disposal of this HLW would require qualifying HLW glass for this repository. Germany was planning a repository to handle primarily HLW glass but had some diflicult-10-reprocess spent fucl that would require special handling. By exchange of equivalent amounts of waste, both parties lowered their waste management costs and probably improved saficty by allowing cach country to concentrate and specialize on disposal of a specific waste form. A similarly mutually advantageous option might exist for the U.S. and Germany, whereby the U.S. would dispose of some of the German vitrified HLW and the Germans would dispose of U.S. HTGR fuel along with their own AVR fucl.

In the U.S., there has also been limited consideration of graphite as an advaned material of construction for waste packages in the repository. ${ }^{3}$ The rationale for consideration of 
graphite as a package material is based on its very low corrosion rate under repository conditions. This does not provide automatic acceptance of HTGR spent fuel as a waste form, but supports the perspective that graphite is highly inert and may prove to be an acceptable repository material.

\subsubsection{Comparison of the Characteristics of HTGR Spent Fucl with Repository Acceptance Requirements}

In the discussion that follows, the characteristics of HTGR spent fuel are evaluated against postulated acceptance criteria for a repository.

\subsubsection{Allowable Release Rates for Radionuclides from the Repository}

For HTGR spent fuel, there are two primary issues: (1) release of fission products/ actinides from the fucl microspheres, and (2) release of radioactive ${ }^{14} \mathrm{C}$ from the graphite block. The coated particles and the SiC coatings on the fuel particles must fail before fission products and actinides can escape the spent fuel, but any oxidation of the graphite block releases some ${ }^{14} \mathrm{C}$ as $\mathrm{CO}_{2}$.

The expected corrosion process for a graphite fucl assembly in an air environment is slow oxidation of graphite. There have been numerous studies of graphite oxidation (Appendix C) including oxidation studies of nuclear grade graphite in air at elevated temperatures. These studies were conducted to evaluate storage of HTGR fuel elements and behavior of HTGR fuel elements under extreme reactor accident conditions. For a nominal graphite temperature of $150^{\circ} \mathrm{C}$, the calculated oxidation rate based on experiments at higher temperatures is $1 \times 10^{-17} \mathrm{~g} / \mathrm{cm}^{2} \cdot \mathrm{s}$ ( $\mathrm{sec}$ Appendix $\mathrm{C}$ ). Actual repository temperatures will vary with time. Initial temperatures may be higher, but U.S. regulations require the waste package to last 300 to 1000 years. By the time of package failure and air exposure to graphite, the temperatures will be significantly less and below $150^{\circ} \mathrm{C}$ at the surface of the graphite. With scoping, idealized calculations (Appendix C) of the oxidation rate of graphite, it is estimated to take $7 \times 10^{9}$ years to oxidize $1 \mathrm{~cm}$ of graphite. 
The regulations on release rates of fission products and actinides are for a period of 10,000 years-a time period over which no significant oxidation of graphite is expected. If the graphite retains its integrity, there will be very little release of these radionuclides over the time period of interest due to oxidation. Even if the graphite should fail earlier, the $\mathrm{SiC}$ is even more resistant to oxidation, corrosion, or external physical damage. The HTGR spent fuel element would, by this analysis, meet repository EPA regulations on tission product and actinide release limits.

A second consideration is the release of ${ }^{14} \mathrm{CO}_{2}$ via oxidation of the graphite. The allowable EPA release limits for ${ }^{14} \mathrm{C}$ from the repository, if it is the only radionuclide of concern, is $100 \mathrm{Ci}$ per 10,000 years for each 1,000) MTIHM. A single fuel element has an exposed surface area of $5.2 \times 10^{4} \mathrm{~cm}^{2}$. With the above calculated oxidation rate of graphite, the carbon loss per fuel element is calculated to be $1.6 \times 10^{.5} \mathrm{~g} /$ year.

Most of the ${ }^{14} \mathrm{C}$ is in the graphite. Typical expected levels are $10 \mathrm{Ci} / \mathrm{MTIHM}$. Some of the ${ }^{14} \mathrm{C}$ is with the fucl and would not be released with graphite oxidation. A single block contains $90 \mathrm{~kg}$ of graphite with $\sim 10 \mathrm{~kg}$ of fuel. Thus, the fractional release rate of ${ }^{14} \mathrm{C}$ compared to the EPA standard can be calculated. The expected fraction of the EPA allowable releases for ${ }^{14} \mathrm{C}$, assuming the ${ }^{14} \mathrm{C}$ is uniformly distributed is $1.8 \times 10^{-4}$.

The NRC release limit of $10^{-5}$ fraction per year of the waste 1000 -year inventory is also met by the HTGR fuel assembly under oxidation scenarios. With an expected block oxidation rate of $1.6 \times 10^{-5} \mathrm{~g} /$ year and 90,000$) \mathrm{g}$ ol' graphite per block, the fractional release rate is $1.8 \times 10^{.9}$ per year for the ${ }^{14} \mathrm{C}$. The release rates of other radionuclides (fission products and actinides inside the SiC-coated particles) are much lower.

The above analysis indicates that in the environment expected at the Yucca Mountain repository, the HTGR intact spent fuel has outstanding characteristics as a waste form. The real limits of performance will not be oxidation, but one of the following: 
- Cracked HTGR fuel elements. Limited examination of HTGR spent fuel does not show serious degradation, ${ }^{4}$ but some damaged fuel elements must be expected if there is a large deployment of reactors fueled with such a fuel. Localized cracks have been observed in at least two elements.

- Potential water leaching of the spent fuel in the repository. There is the possibility for some percolation or dropwise flow of water through the repository. Measurements of corrosion rates of graphite under conditions that might be expected at Yucca Mountain have not been identified, but graphite is known to resist attack by conventional aqueous reagents. In the chemical industry, graphite heat exchangers are used for very highly corrosive conditions when most metals fail. Graphite is generally considered "completely inert to all but the most severe oxidizing conditions." ${ }^{16} \mathrm{SiC}$ is also highly resistant to both oxidation and aqueous corrosion.

- Degradation mechanisms that are unidentified as of yet.

- Under extreme accident scenarios (e.g., carthquakes or volcanic activity) the graphite blocks could fracture and oxidize, but the coated particles would still survive.

Given the calculated performance of HTGR spent fuel as outlined above, there is no known degradation mechanism that will prevent HTGR fuel elements from meeting repository performance requirements. If there is a problem with performance, it will come trom an unidentified mechanism.

\subsubsection{Allowable Organics in a Repository}

Disposal sites will generally limit the presence of organics in a repository. The basis for such restrictions is that some organics (complexing agents) can solubilize fission products and actinides with subsequent transport of such materials by water to the open environment. These complexing agents are usually complex compounds containing carbon, hydrogen, oxygen, and, not infrequently, nitrogen or sulfur. 
HTGR spent fuel elements do not contain organic compounds. The fabrication procedure (and reactor operating conditions) will have graphitized (or driven off) all organics that might have been present.

\subsubsection{Combustibility}

The NRC limits combustible radioactive wastes (10 CFR 61.135:C:3) in a repository. Specifically, "all combustible radioactive wastes shall be reduced to a noncombustible form unless it can be demonstrated that a fire involving the waste packages containing combustibles will not compromise the integrity of other waste packages, adversely affect any structures, systems, or components important to safety, or compromise the ability of the underground facility to contribute to waste isolation."

Block graphite is highly inert and generally will not burn without a sustained outside heat source to maintain burning conditions. Some very limited information is available on nuclear grade graphite based on early research on HTGR reprocessing where the first process step was to burn off the graphite. ${ }^{7}$ Block graphite, based on experiment, normally does not burn for three reasons.

- It has a very low surface-to-volume ratio that limits burning. The rate at which oxygen can reach the surface is very slow.

- It is highly inert. Most organics (including coal) burn by decomposition of the fuel as it is heated, which releases combustible gases and breaks up the surface. Graphite does not contain hydrogen or water, thus, no mechanism exists for breakup of the surface and release of combustible gases. The higher the carbon content of the fuel and the density, the lower the combustibility.

- It is highly conductive, which reduces the probability of "hot spot" formation that can lead to or support combustion. 
Block graphite will burn if an external heat source is provided. The combustion of graphite at Chernobyl occurred because reactor decay heat from fission products (which melted metals and decomposed concrete) kept the graphite at very high temperatures. The temperature levels in a reactor accident are much higher than even the extreme values envisioned in worst-case repository accident scenarios.

\subsubsection{Comparison of HTGR and LWR Spent Fuel Under Repository Conditions}

Work to date indicates that direct disposal of LWR spent fuel in the proposed repository will be acceptable although the final package and/or overpack has not yet been designed. If HTGR spent fuel can be shown to be superior to LWR spent fuel in a repository, it follows that direct disposal of HTGR spent fuel will be aceptable. The chemical and physical designs of LWR and HTGR fuels are very different; thus, their repository performance differs significantly. The chemical and physical differences can be considered separately.

\subsubsection{Physical Effects}

The HTGR fuel block with microsphere fuel geometry minimizes the consequences of many types of failure compared to LWR spent fuel. A single LWR pin in a fuel assembly contains a significant quantity of fuel ( 2 to $4 \mathrm{~kg}$ ). Thus, a random clad failure exposes a significant amount of fuel to the repository environments. A single HTGR microsphere in a fuel block contains only a very small quantity of fuel (1 to $5 \mathrm{mg}$ ). Thus, a random coating failure does not expose a significant amount of fuel to the environment. This difference in geometry may give the HTGR fuel element some advantages over the LWR for certain failure modes. For example, the geometry effect is particularly important in the release of potentially gaseous fission products $\left({ }^{129} \mathrm{I},{ }^{14} \mathrm{C}\right.$ as $\mathrm{CO}_{2},{ }^{85} \mathrm{Kr}$, and $\left.{ }^{3} \mathrm{H}\right)$ where pinhole clad failt - depressurizes the pin or microsphere with immediate release of these radionuclides. 


\subsubsection{Chemical Elfects}

This discussion assumes mildly oxidizing and potentially wet repository conditions such as expected at the proposed U.S. repository at Yueca Mountain in Nevada. Under oxidizing conditions, all the major components af both HTGR and LWR spent fuel are thermodynamically unstable. Given sulficient time, zitconium (zircaloy is $99 \% \mathrm{Zr}$ ) would convert lo zirconium oxide, graphite to carbon dioxide, uranium dioxide to uranium trioxide $\left(\mathrm{UO}_{3}\right)$, and uranium carbide to the oxide. The rales of these conversions depend on the kinctics of the reactions.

Oxidation of $\mathrm{UO}_{2}$ (LWR spent luel) or uranium oxycarbides (HTGR spent fuel) in a repository is undesirable for two reasons, ${ }^{8,9}$ First, oxidation beyond $\mathrm{U}_{3} \mathrm{O}_{7}$ to $\mathrm{U}_{3} \mathrm{O}_{8}$ or higher causes physical breakdown of dense, crystalline uranium fuel forms. This is because the molar volumes of the higher oxides are signilicantly larger. Physical disruption of components increases the exposed surlice area, and enhances release of fission products and actinides.

The other negative aspect of oxidation is that $\mathrm{UO}_{3}$ (hexavalent $\mathrm{U}$ ) is much more soluble than uranium fucl forms. ${ }^{10}$ (This is why fuel reprocessing plants use nitric acid, which is oxidizing, in order to dissolve $\mathrm{UO}_{2}$.) The typical uranium fuel forms are highly insoluble ${ }^{10}$ in water. Fission products and actinides cannot be released from the fuel until degradation of the uranium fuel structure. Fully oxidized uranium ( +6 valence state such as in $\mathrm{UO}_{3}$ ) is the most soluble form of uranium. Il waler is present, the uranium dissolves and is leached away from the fuel exposing the other actinides and fïssion products to repository air and groundwater.

The above considerations indicate that the best waste form will be the waste form where the "cladding" protecting the fuel has the slowest kinctics of oxidation. The lower the oxidation rate of the "cladeding," the longer will be the period preceding exposure of the uranium fuel to the oxidizing (or wet) environment. 
The relative stability of HTGR and LWR spent fucl can be compared using idealized, scoping calculations to determine the lime to oxidize the graphite or zircaloy and expese the fuel to the repository environment.

For graphite, the oxidation rate is extremely slow. In Sect. 5.2.1, it was calculated to take $3.6 \times 10^{9}$ years to oxidize $0.5 \mathrm{~cm}$ of graphite to expose HTGR fuel rods. More is given on this topic in Appendix C. For zircalioy, the rate of oxidation has been measured and expressed as:"

$$
\begin{gathered}
\Delta M=3.25 t \times 10^{4} \exp \left[-22,200 / R^{\prime} T\right] \\
\Delta M=\text { mills } \\
T={ }^{\circ} \mathrm{K}\left(150^{\circ} \mathrm{C}=42.3^{\circ} \mathrm{K}\right) \\
R=\text { gas constant }(1.987) \\
t=\text { days. }
\end{gathered}
$$

For a typical LWR clad thickness of $25 \mathrm{~mm}$, the time for unilorm oxidation through the clad is $5 \times 10^{5}$ years. Like HTGR spent fucl, uniform oxidation is unlikely to be the limiting factor in LWR waste form performance.

Even so, these simplified calculations indicate that HTGR fuel elements are orders of magnitude more inert than LWR luel elements under oxidizing repository conditions and should exhibit superior performanec as a waste form. Note also that no credit was taken for the $\mathrm{SiC}$ coatings on the HTGR fuel form; the coatings themselves are designed to isolate the fuel.

As indicaled above, once the prolective layer of graphite is breached, HTGR fuel is still protected by the SiC coaling. For LWR livel, however, onee the zircaloy cladding is breached, the $\mathrm{UO}_{2}$ fuel is exposed to oxidation. 'This occurs at a measurable rate of temperatures as !ow as $150^{\circ} \mathrm{C}$ (sec Appendix B). 


\subsubsection{Combined Physical Form and Chemical ElTects}

Under certain circumstances physical form and chemical effects can combine to cause special problems. One such example is the potential release of ${ }^{14} \mathrm{C}$ from LWR spent fuel at the proposed Yucea Mountain repository. ${ }^{12}$ In an LWR fuel assembly, the ${ }^{14} \mathrm{C}$ is on the surface of the elad, in the fuel and in the form of gascous $\mathrm{CO}_{2}$ in pressurized fuel pins. A failure of the waste package can allow air in to oxidize carbon on the fuel clad to $\mathrm{CO}_{2}$. Any failure of the cladding also results in release of the gaseous $\mathrm{CO}_{2}$ containing the ${ }^{14} \mathrm{C}$. There is concern about exceeding the $10^{.5}$ fraction/year allowable ${ }^{14} \mathrm{C}$ releases at the Yucca Mountain site with LWR fucl. ${ }^{12}$ While LWR fuel contains less ${ }^{14} \mathrm{C}$ than HTGR spent fuel, ${ }^{14} \mathrm{C}$ releases are predicted to be higher for LWR fuel than for HTGR fuel because of the ehemical and physical differences between the two luel types.

\subsubsection{Options for Improved Whole Block Disnosal}

The preceding analysis eonsidered whole block disposal of HTGR spent fuel as discharged from the reactor. The preliminary analysis indicates excellent performance as a waste form. There are two conditions under which better performance may be desired:

- There may be other mechanisms for failure that have not yet been identified.

- There may be badly failed fucl.

Better waste performance is possible by two techniques-better waste packages and improved whole block HTGR waste forms. Belter packaging is an option for all waste forms and will not be further discussed herein. The performance of the fuel element itself as a waste form might be improved by the following techniques.

- Block coolant channels with graphite plugs. Air or water reactions with graphite are surface phenomena. Most of the surface area of a fuel block is in the coolant channels. 
If the coolant channels are plugged, the surlace area (and area for chemical reactions) is reduced by $77 \%$.

- Coat the graphite block with a protective surface coating. There has been limited research in the reactor community to improve chemical resistance of HTGR fuel blocks under severe accident conditions-typically air at temperature of $-1600^{\circ} \mathrm{C}$. Coating options include ceramics such as $\mathrm{SiC}$. Such coatings may also reduce long-term oxidation rates.

\subsection{REPOSITORY ENGINEERING AND COST CONSIDERATIONS}

\subsubsection{Repository Enginecring Limits}

The first issue with proposed disposal of any type of waste in a repository is whether it can be disposed of in its current form. If the answer is yes, the next issue is cost. Repository cost estimation a highly complex issue; but some estimates of relative HTGR spent fuel disposal costs compared to LWR spent fuel disposal costs can be made based on the characteristics of the two waste forms. 'To make such comparisons, some understanding of the enginecring limits of repositories is required.

The cost of a repository depends on three waste characteristics: (1) heat generation rate, (2) volume, and (3) chemical/physical properties.

- Repository design and cost is controlled by radioactive decay heat. If waste decay heat levels are excessive, the corresponding high temperatures may damage the waste form/package, cause stress in the rock with the potential for tunnel or cooling wall collapse, or damage the rock. In cach case, repository performance is degraded. To avoid high repository temperatures, waste canisters are separated from each other in the repository with the separation distance increased for waste packages with higher decay heat levels. The proposed repository design for the proposed Yucea Mountain repository separates LWR spent fuel waste canisters by $4.57 \mathrm{~m}$ in each tunnel with 
tunnels spaced $38.4 \mathrm{~m}$ apart. ${ }^{13}$ For the proposed Yucca Mountain repository, over $160 \mathrm{~km}$ of tunnels are required to spread the heat level unclerground and avoid local overheating. This repository design requirement drives the costs.

- A second design constraint and cost driver is waste volume. Larger waste volumes require more waste packages or larger waste packages. Larger waste packages are more economical, but there are two possible constraints:

1. Heat load per waste package must be limited to avoid overheating the waste.

2. Large packages may be more difficult to handle underground. In the specific case of the proposed Yucca Mountain repository, this is a relatively minor constraint because truck access to the repository is planned. With hoist (shaft) access, there are usually significant weight/size limitations. The major sensitivity of waste volume as a cost driver derives from experience with vitrified HLW, however, it seems implausible that the cost leverage for large volumes of spent fuel will be comparable to the costs associated with glass or other encapsulated waste forms.

- A third constraint and cost driver is waste characteristics. If wastes are chemically unstable or have other unusual characteristics, special waste packages may be required.

\subsubsection{Heat Limits}

The heat generation rate per unit volume of HTGR spent fuel is 5 to $10 \%$ of that of LWR spent fuel. This implies that 10 to 20 times as much spent fuel by volume can be emplaced per kilometer of disposal tunnel in a repository compared to LWR spent fuel. This can be done by use of larger waste packages or closer spacing of waste packages or some combination. 


\subsubsection{Volume Limits}

A potential disadvantage of the whole block disposal form for HTGR fuel is the large volume of the fuel element relative to the fuel content in an LWR assembly. A typical waste canister for the Yucca Mountain repository is sized to contain a mix of PWR and BWR assemblies equivalent to a spent fuel quantity of about 1 MTIHM. By comparison, a previous study assumed that an equivalent waste canister would contain a vertical stack of four FSV fuel blocks, or approximately $40 \mathrm{~kg}$ of heavy metal. ${ }^{14}$ This factor of 25 difference between the HTGR whole block disposal and LWR fucl disposal is a source of concern. If only the current HTGR spent fuel must be disposed of, it is likely that a modified version of the proposed existing waste canister would be used so that HTGR spent fuel could be handled with the same emplacement equipment planned for LWR spent fuel or HLW. If large quantities of HTGR spent fuel are generated in the future, part of the repository and the waste package would be optimized for HTGR spent fuel (see below). If the quantities of HTGR spent fuel were larger than current inventories, but insufficient to reoptimize the repository system, the intermediate option of reoptimizing the waste package exists. The options include:

1. Taller canisters. Two sizes , f canisters are typically assumed for the repository: (1) 26 in. by $12 \mathrm{ft}$, and (2) $26 \mathrm{in}$. by $15 \mathrm{ft}$. If use of the taller canister is assumed, then FSV fuel elements can be stacked six high, increasing canister capacity to about 60-kg heavy metal (HM).

2. Larger diameter canisters. Canister diameter is limited mainly by thermal considerations, given the thermal heat projected for LWR fuels. Within this limit, waste package size is optimized based on handling, criticality, economic and other considerations given the expected range of waste to be disposed. The lower thermal power density of HTGR fuels should enable the use of larger waste canisters. If there were large quantities of HTGR spent fuel, the waste package would be optimized for HTGR spent fuel. 
Illustrative sketches of strategies for emplacing HTGR blocks in larger diameter canisters are shown in Fig. 4.3. A canister $37 \mathrm{in}$. by $15 \mathrm{ft}$ would be capable of containing six layers of three FSV blocks each, approximately $180 \mathrm{~kg} \mathrm{HM}$. A larger canister $47.3 \mathrm{in}$. by $15 \mathrm{ft}$ (Fig. 4.3) would contain 42 FSV blocks, or about $420 \mathrm{~kg} \mathrm{HM}$.

The thermal output of a 5-year old FSV fuel packaged 18 blocks per canister would be about $450 \mathrm{~W}$. This is far less than that for LWR fuel, for which the upper limit is about ten times higher. It is in the same range as vitrified defense program HLW, estimated at 300 to $800 \mathrm{~W}$ per canister.

3. Closely spaced boreholes. The distance between boreholes in the repository design is set by thermal considerations for high heat wastes and structural considerations for low heat waste (collapse of wall between borcholes). Given the lower thermal density of HTGR fuel, it should, in principle, be possible to decrease the distance between boreholes containing HTGR fuel, thus increasing repository capacity. This option needs further study in order to assess its feasibility and advantages.

Given the quantities of currently existing HTGR spent fuel, as discussed in Sects. 3.2.2 and 3.2.4, systems will require as many as 7()0 canisters (if FSV fuel is emplaced at 4 to a canister), or as few as 200 canisters or less (if larger canisters are used). For comparison, it is projected that there may be 15,000 canisters of vitrified HLW and 45,000 canisters of LWR spent fuel. Thus, the whole block disposal of HTGR fuel is not expected to have a major impact on repository capacity unless a large-scale deployment of HTGR technology is undertaken.

\subsubsection{Waste Form}

Earlier scoping calculations (Sect. 5.4) suggest HTGR spent fuel is a superior waste form to LWR spent fuel. This should simplify licensing and may reduce cost per unit volume for the waste package. 


\subsubsection{Relative HTGR and LWR Spent Fuel Disposal Costs}

If there are only small quantities of HTGR spent fuel to dispose of, the proposed standard waste canisters would be used. It would be uneconomical to develop custom waste packages and custom waste handling equipment for small quantities of waste.

If there is large-scale deployment of HTGR technology, part of any proposed repository would be optimized for disposal of HTGR spent fucl. Repository design involves complex tradeoffs. Consequently, it is unclear whether an optimized design for HTGR whole block spent fuel disposal would be more or less expensive then LWR spent fuel disposal per unit of electricity generated. The reasons for this conclusion are as follows.

- Repository cost is primarily controlled by decay heat load. An LWR has a power plant efficiency of 32 to $35 \%$ vs 38 to $40 \%$ for a HTGR. The $20 \%$ greater power plant efficiency of the HTGR implies $20 \%$ less decay heat in spent fuel per unit of electricity generated. Twenty pereent less decay heat per unit of electricity generated implies $20 \%$ fewer tunnels required in the repository per unit of electricity generated to spread out the heat level underground.

- The geometry of the HTGR spent fuel assembly allows a more optimized waste package/repository design than for LWR spent fuel with significant cost savings per unit volume. This is self evident when comparing the optimized repository designs for disposal of LWR spent fuel in the U.S. vs disposal of Canadian heavy-water reactor (CANDU) spent fuel in Canada. LWR spent fuel is 4- to 5-m long. CANDU spent fuel is $\sim 0.5 \mathrm{~m}$ long. The HTGR spent fucl is $\sim 1-\mathrm{m}$ long, thus, an optimized repository design for HTGR spent fuel would more closely resemble Canadian designs. These differ from U.S. designs in three respects:

1. The lowest cost waste package minimizes surface to volume ratio by use of a package where the ratio of package height to diameter is 1 to 1 . For the U.S. waste package, the ratio is $\sim 7.2$. For the Canadian waste package, the ratio is 3.5 (four CANDU 
spent fuel bundles high). An optimum HTGR package would probably be close to the Canadian design.

2. The height of disposal tunnels is determined by length of the disposal package. The underground waste transporter to emplace fuel vertically orientates the waste package and lowers it into a borchole in the floor of the tunnel. The long U.S. waste package (to handle LWR spent fuel) has resulted in a proposed U.S repository tunnel height of $6.7 \mathrm{~m}$ vs $4 \mathrm{~m}$ for the Canadian design. This implies $50 \%$ more rock removal per kilometer of tunnel due to long package length. Fuel element geometry strongly impacts repository tunnel cross section and cost.

3. The large volume of HTGR spent fuel per unit of electricity implies more and larger packages.

\subsection{REFERENCES}

1. H. Brucher, et al., "Disposal of Spent HTGR Fucl Elements," Proceedings of the Second Annual International Conference on High Level Radioactive Waste Management, Las Vegas, Nevada, 1991.

2. N. Kirch, H. U. Brinkmann, and P. H. Brücher, "Storage and Final Disposal of Spent HTR Fucl in the Federal Republic of Germany," Nucl. Eng. and Design, 121:241 (1990).

3. W. Clark, Lawrence Livermore National Laboratory, Livermore, California, personal communication to C. W. Forsberg, Oak Ridge National Laboratory, Oak Ridge, Tennessee, September 16, 1991.

4. F. McCord and J. J. Saurwen, Remote Examination of Fort St. Vrain HTGR Fuel and Reflector Elements, GA-A-17469 (March 1984). 
5. J. J. Saurwein, Nondestructive Examination of 54 Fuel and Reflector Elements from Fort St. Vrain Core Segment 2, GA-A16829 (October 1982).

6. Perry, J. H., et al., Chemical Engineers Handbook: Fourth Edition, McGraw Hill (1963).

7. D. T. Young, Fluidized Combustion for Beds of Large, Dense Particles in Reprocessing HTGR Fuel, GA-A14327 (March 1977).

8. M. J. Apted, et al., Preliminary Calculations of Release Rates from Spent Fuel in a Tuff Repository, UCRL-JC-104832 (1991).

9. R. B. Stout, et al., "LWR Spent Fuel Waste Form Characteristics: "Grain and Fragment Size Statistical Dependence for Oxidization Response," Proceedings' of the Second Annual International Conference on High Level Radioactive Waste Management, Las Vegas, Nevada, 1991.

10. K. S. Deffeyes and I. D. MacGregor, "World Uranium Resources," Scientific American (January 1980).

11. R. E. Einziger, Effects of an Oxidizing Atmosphere in a Spent Fuel Packaging Facility," Proceedings of Focus 1991, Las Vegas, Nevada, September 29-October 3, 1991.

12. C. Pescatore and T. M. Sullivan, "Potential $\mathrm{CO}_{2}$ Releases from [LWR] Spent Fuel Containers at Yucca Mountain," Proceedings of the Second Annual International Conference on High Level Radioactive Waste Management, Las Vegas, Nevada, 1991.

13. C. W. Forsberg, Representative Geological Repository Designs for Spent Fuel and HighLevel Waste, K/ITP-39.3 Martin Marictta Energy Systems, Inc., K-25 Site, January 1991. 
14. R. Salmon, and K. J. Notz, Non-LWR and Special LWR Spent Fuels: Characteristics and Criticality Aspects of Packaging and Disposal, ORNL/TM-11016, Martin Marietta Energy Systems, Inc., Oak Ridge National Laboratory, January 1990. 


\section{DISPOSAL WITH REMOVAL OF GRAPHITE}

\subsection{OPTIONS AVAILABLE}

As previously discussed, optimization of the economics of disposal of HTGR spent fuel elements may dictate that the spent fuel be separated from the graphite. Particularly, this would be of great advantage if the fuel and bulk graphite could be cleanly separated, allowing the graphite to be disposed as a LLW and allowing the spent fuel to be emplaced in less volume in the repository. There are two general options available for separation: physical or mechanical separation of the fuel from the graphite block and burning of the fuel element, either as a whole fucl element or after having been crushed.

\subsection{PHYSICAL SEPARATION OF GRAPHI'TE}

Recovery of essentially intact fuel rods or sticks (e.g., by pushing or vibrating them out of the graphite block) would be the lavored method for physical separation. There has only been limited experience with this method, primarily the recovery of fuel rods from test irradiations and from examination of at least one fuel element. This method should result in very sharp separation of the spent fuel and the graphite block material, and, if the particle coatings have performed to their potential, there should be very little fission product contamination of the graphite. Disposal of the graphite block as LLW will depend upon high performance of the particle coatings and the fuel rod matrices. But, of eourse, both of these are primary objectives of the fuel element design because of the need to maintain a clean helium-cooled primary system in the reactor.

Other methods such as core drilling or mechanical machining (milling) would appear feasible, but these have the disadvantage of almost certainly damaging some fuel particle coatings thus degrading the spent fuel and undoubledly increasing radioactivity of the graphite block. Machining and crushing might also be used to obtain an all granular fuel product. Limited crushing followed by size screening or density separation are possibilities for performing 
separation. However, any method that subjects the particles to significant mechanical stresses is not desirable for the reason stated above.

Regardless of the recovery method, intact fuel rods will likely contain substantial amounts of associated carbon matrixed with the fuel particles. Under the best conditions, physical separation of graphite will leave a concentrated high activity fuel stream of lower volume and a low activity graphite stream of about the same volume as the original fuel element. (Fuel rods represent only a small fraction of the fuel block.) The combined volume of the two streams (the graphite stream now at a lower bulk density than before) will be greater than the original fuel element volume. Under less than ideal conditions and depending to some degree upon the ultimate storage/disposal criteria, physical separation by itself could result in larger total volumes to handle and activity of the graphite stream compromised. The separation should be considered only if the graphite block can be disposed as an LLW.

\subsection{CHEMICAL SEPARATION OF GRAPHITE (BURNING)}

In this method, graphite is simply burned away from the fuel particles while carbon dioxide is formed as a product of the combustion. Release of the $\mathrm{CO}_{2}$ to the atmosphere, even after removal of the noble gases and other fission products, is prohibited on any large scale due to the ${ }^{14} \mathrm{C}$ content. The potential for life cycle and carbon dating impacts are principal concerns. Thus, disposal of graphite by burning will likely require fixation of the carbon dioxide (e.g., as calcium carbonate) and will only partially mitigate storage/disposal requirements for the graphite (carbonate) stream.

Burning produces a large quantily of carbon dioxide that must be processed because of ${ }^{14} \mathrm{C}$ that is present in the graphite. However, carbon dioxide is an acid gas that is easily removed by scrubbing with lime water. A carbonate precipitate is formed that can be separated and dried for storage. Previous work that assumed shallow land burial of $\mathrm{CaCO}_{3}$ (or $\mathrm{CaCO}_{3}$ fixed in concrete) concluded that separaling the bulk of the graphite fuel block from the fuel particles was unattractive on both technical and economical grounds. 'The total waste 
volume is several times the original whole block volume. If fuel rods are removed and burned, the resulting waste volume is about hall the initial whole block volume.

\subsection{POSSIBLE IMPROVEMENTS TO FUTURE HTGR FUEL}

The properties of fuel have been discussed from the standpoint of the status of development for the two principal HTGRs in the U.S. The FSV reactor fuel was designed with the assumption that the fuel would be recycled; thus, there was not a large incentive to develop means of separating fucl and graphite physically. Certainly, there are possible improvements to future HTGR luels that would make the disposal of HTGR fuel in a repository more economical or could improve the perlormanee of the fuel in a repository. Thus, future HTGRs are not necessarily restricted to the range of properties of existing fuels.

HTGR fuel, if stored as a whole fuel element, does have the disadvantage of requiring considerably more volume for storage of a unit weight of luel and fission product isotopes. Thus, improvements in the luel design and performance to enhance the feasibility of separation of graphite from the spent luel should be considered. The question is, Can the graphite be kept sufficiently clean to allow disposal of the separated graphite as an LLW? Improvements in the performance of coatings will enhance the feasibility of disposing of graphite as an LLW. Use of parting materials, such as graphite powder, between fucl rods and the walls of the fuel holes could be used to enhance the mechanical separation of fucl rods from the bulk fuel blocks and might even improve thermal performance of the fuel element in the reactor.

Failure of particle coatings does increase the likelihood of migration of fission products to the graphite block, although the graphite in the fucl structure (fuel rod) also acts as a barrier. It was previously noted that FSV luel has a coating failure rate of 0.3 to $0.5 \%$. Later fuel should be considerably improved. Improvements in performance can be reasonably expected as process control improves and more advariced coating materials are used. 
Separation of fuel rods from graphite has been done by GAC. ${ }^{2}$ As a part of the examination of FSV fuel element 1-0743, it was necessary to separate the fuel rods from the graphite block. Using a tool especially designed for the task, GAC cored out the fuel hole plugs at the top of the element and the graphite containment at the bottom of the element. The fuel rods were removed from the element by breaking out the cored sections and pushing the fuel rod stacks into a recelving trough. The luel stacks were pushed out with either a metal rod or a special device designed to measure the push-out forec. The push out forees were generally low; but, in a few cases the forees were higher (up to $10 \mathrm{~kg}$ ), which was believed to be caused by misalignment of the fiuel hole and the receiving trough. It was concluded that there was no appreciable incraction between the fuel block and the fuel rods in fuel element $1-() 743$.

\subsection{STATUS OF TECHNOLOGY}

Separation of the fuel particles from the graphite matrix was anticipated in the design of the HTGR fuel element and several metheds have been investigated. Unirradiated whole blocks have been successfully burned to disengage the fuel particles. ${ }^{3}$ Block breaking, crushing, and subsequent burning using a fluidized bed has also been perlormed in cold prototype equipment. ${ }^{4}$ Small scale burning of irradialed HTGR fuel has been done. ${ }^{5}$ Complete development of such techniques would require additional hot experimental testing with subsequent large scale demonstration of integrated operations. However, integrated demonstration facilities do not currently exist and no "licensable" facilities are presently planned.

In summary, removal of graphite by burning does not appear to be a better option of the two methods presented in view of the great increase in volume upon solidification of the $\mathrm{CO}_{2}$ into carbonate. Physical removal of graphite from fucl rods will not likely be a sharp separation with existing fuel elements, but it is an available technology. There are undoubtedly means of improving separation through changes in the fuel element design. 
If physical separation is to be lurther explored, it will be important to develop fuel designs espectally tailored for separation and lo concentrate on very low particle failure rates, both of which would appear to be deulistic objectives. It will be necessary to prove that fission product contamination is sulticiendly low to enable disposal of the graphite blocks as LLW. In addition, lurther work should be considered for other noninvasive means of separating graphite and fuel, such as electrolytic melhods, which have been used to separate intact conted particles from fuel rod matrices in post-irradiation examination of fucl.

For disposal, the fuel rods can be simply loaded into the canister, but the rods may require some containment in a matrix. Separated lucl particles with residual graphite can be embeded in grout lo provide complece lirepresting should that be required for repository storage. It is noted that the SiC eoatings alone ensure good lïre protection of the fuel compounds in the particles.

\subsection{REFERENCES}

1. C. L. Fitzgerald at al., Head-End Processing Development, Annwal Progress Report of GasCooled and Thorium Utilization Programs for Period Ending September 30, 1971, ORNL. 4760), Union Carbide Corporalion, Oak Ridge National Laboratory, January 1973.

2. J. J. Saurwein, C. M. Miller, and C. A. Young, Postirradiation Examination and Evaluation of Fort St. Vrain Fuel Element 1-(074.3, GA-A16258, May 1981.

3. H. Barnert-Weimer and R. S. Lowric, Whole-Block Burner Studies, Annual Progress Report for Gas-Cooled Reactor Programs. for Period Ending December 31, 1972, ORNL4911, Union Carbide Corporation, Oak Ridge National Laboratory, March 1974.

4. D. T. Young, Fluidized Combustion for Beds of Large, Dense Particles in Reprocessing HTGR Fuel, GA-A14327, March 1977. 
5. C. L. Filigerald and V. C. A. Vaughen, Bumer Off-Gas Studies with RTE-2-3, Thorium Utilization Program Progresss Report for Jamuary 1, 1974-June 30, 1975, ORNL-5128, Union Carbide Corporation, Oak Ridge Nalional Laboratory, May 1976. 


\section{DISPOSAL WITH DISSOLUTION OF FUEL}

In this disposal option, fuel reprocessing is carriced out to recover the remaining fissile and fertile values in the spent fuel. The minor actinides (such as $\mathrm{Pa}, \mathrm{Np}, \mathrm{Am}$, and $\mathrm{Cm}$ ) are also recovered and managed separately from the high-level fission product waste. It was assumed that transuranic and other actinide wastes would be incorporated into borosilicate glass.

The technology discussed here is based on a llow sheet developed with the constraints that existed approximately two decades ago. Accordingly, it is based on burning technology. Today, a llow sheet that starts with mechanical separation and other methods for obtaining the particles as discussed in the previous section might be more appropriate. Nevertheless, for simplification, the old llow sheot used as reference for so many years for fuel recycle development is adequate to seope the dissolution and processing option.

\subsection{OVERALL FLOW SHEET}

The chemical processing flow sheel (Fig. 7.1) that might be used for the dissolution option is based on burning technology and consists of the following sequence of operations:

1. Crushing the graphite blocks and burning away the graphite to free the silicon carbide coated particles.'

2. If desired, coated fertile thorium particles when present (e.g., FSV) may be separated from the fissile particles by screening and processing separately as indicated by the solid lines for the lissile material and dashed lines for the thorium-bearing particles. Alternatively, the malcrials from the two particles may be processed together.

3. The particles are then crushed and burned to remove the pyrolytic carbon from the inner coatings and the carbon present as metallic carbides. 


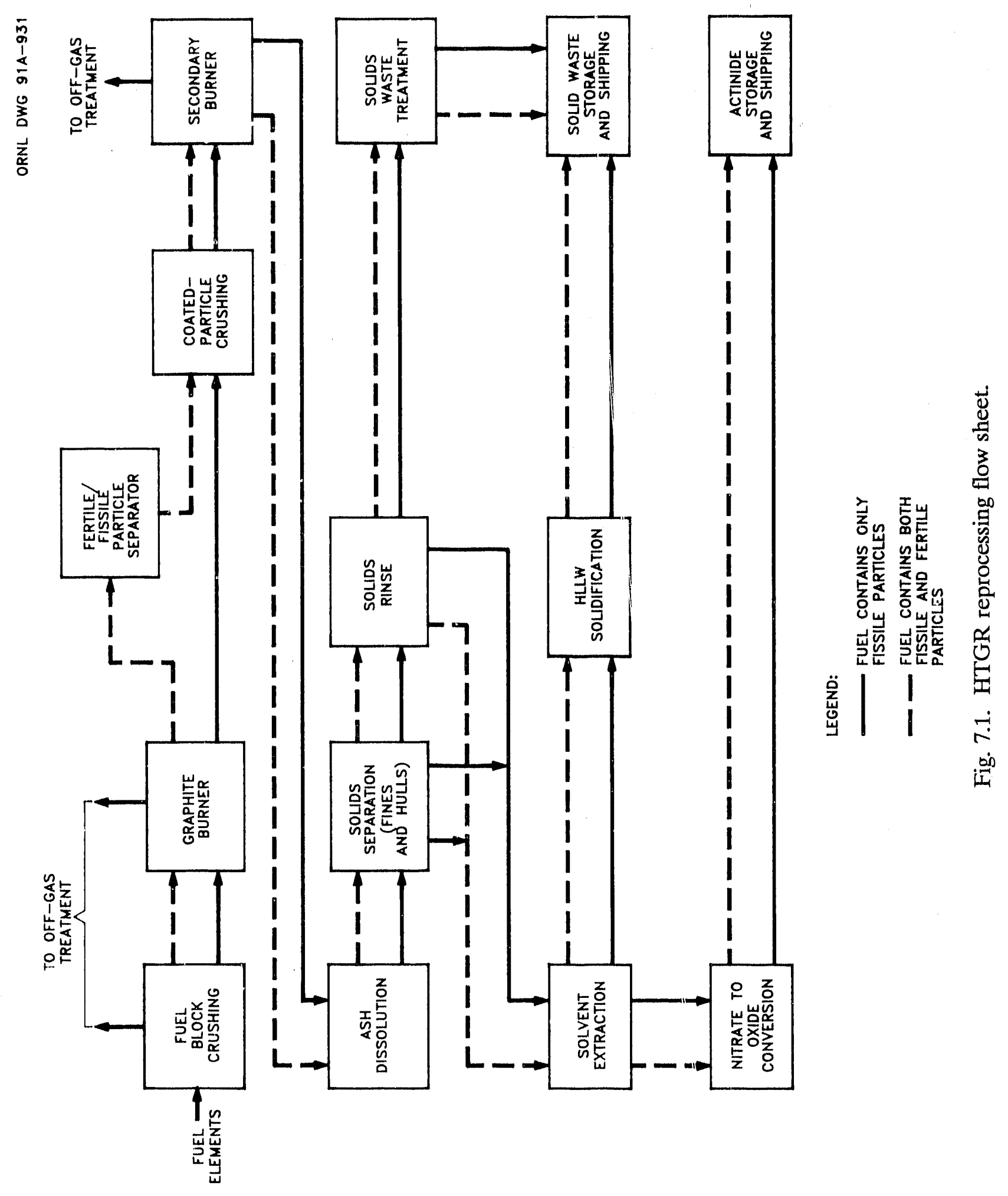


4. The resultant ash plus the gasborne semivolatile particles of fission products (Cs, Ru, etc.) are combined and dissolved in nitric acid. The hull rinse liquid is combined with the dissolver solution, and subsequently adjusted to the proper acidity and heavy metal concentrations for solvent extraction.

5. In solvent extraction (Fig. 7.2), tributyl phosphate (TBP) is employed in a Purex flow sheet to recover $\mathrm{U}, \mathrm{Np}, \mathrm{Pu}$ from fissile material feeds and in a Thorex flow shect to recover Th and $U$. After removal of bulk actinides by Purex or Thorex processing, the minor actinides (Am and $\mathrm{Cm}$ ) are recovered using the TRUEX process ${ }^{2}$ that employs octyl(phenyl)-N, N-diisobutyl carbamolymethylphosphine oxide, typically called CMPO, as the extractant. The TRUEX process employs a mixed diluent of TBP and normal paraffin hydrocarbon (NPH).

6. The product solutions of actinide nitrates are converted to oxides for storage and shipping. It is to be noted the minor actinide oxides ( $\mathrm{Am}$ and $\mathrm{Cm}$ ) also contain the rare earth fission product oxides.

7. The high-level liquid waste (HLLW) from solvent extraction is solidified to borosilicate glass.

8. Off-gases from burning operations and ash dissolution are routed to a treatment system, where the ${ }^{14} \mathrm{C}$ and ${ }^{129} \mathrm{I}$ are trapped and stored. The shorter lived fission gases ${ }^{85} \mathrm{Kr}$ $\left(\mathrm{t}_{1 / 2}=10.73\right.$ years $)$ and ${ }^{3} \mathrm{H}\left(\mathrm{t}_{1 / 2}=12.26\right.$ years $)$ can also be trapped and stored if desired.

\subsection{HEAD-END OPERATIONS}

These operations involve crushing the graphite matrix and burning the graphite in oxygen at $700-750^{\circ} \mathrm{C}$, collecting the silicon carbide coated particles and crushing the SiC-coated particles to make the inner kernel aceessible for its conversion to solvent extraction feed. When fertile and fissile particles are both present, the particles may be separated if that is desirable for recycle, but for terminal storage of all products, separation would not be 


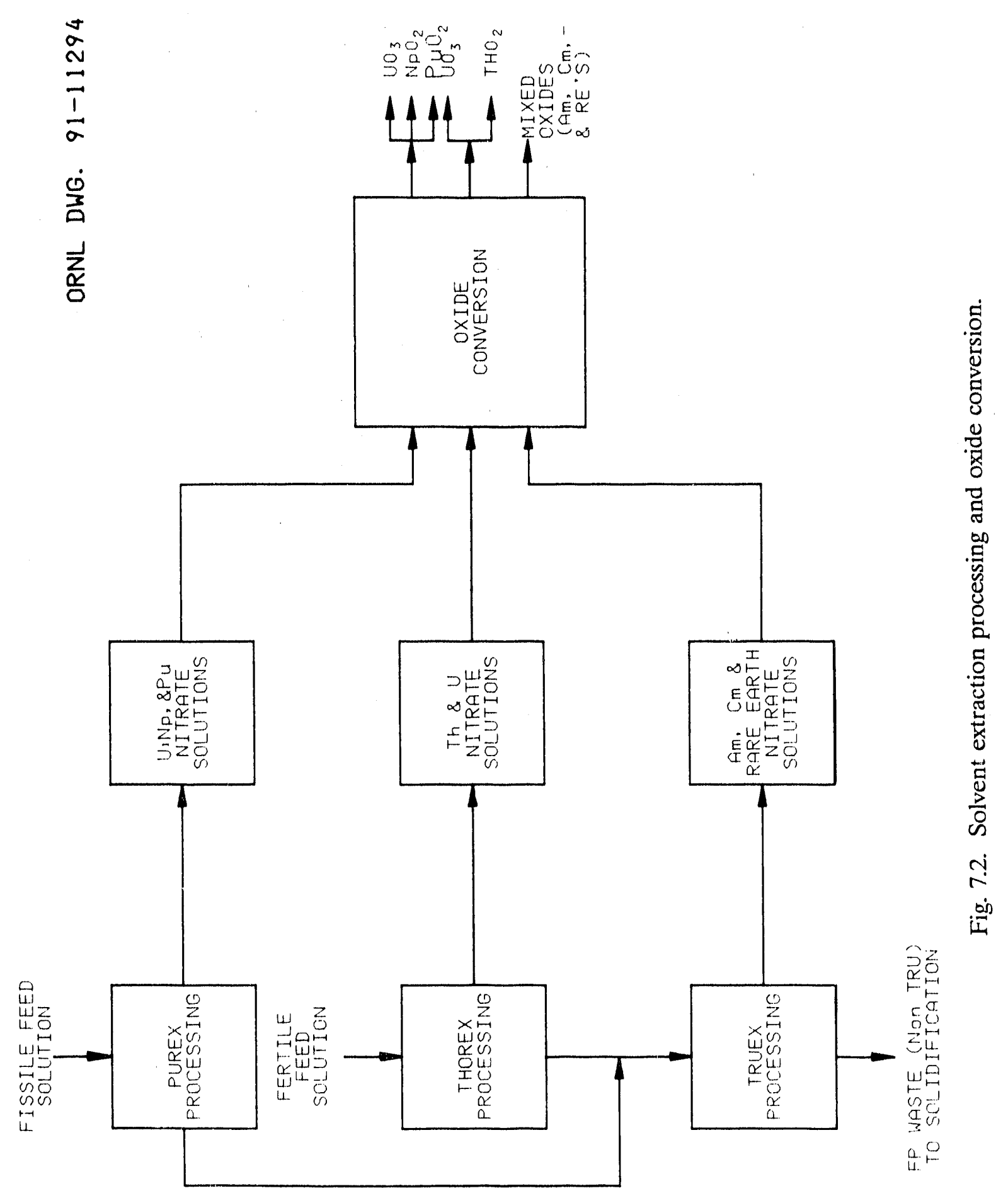


necessary. Before dissolution to make solvent extraction feed, the carbon associated with the kernels (inner pyrolytic carbon coatings and metal carbides) is removed in a second burning, likely fluid-bed combustion. This second burning operation is carried out to ensure that no significant quantity of organic compounds are formed in nitric dissolution which might be deleterious to subsequent solvent extraction operations. The ash is conveyed to a dissolution vessel where it is leached with nitric acid $\left(\mathrm{HNO}_{3}-\mathrm{HF}\right.$ for ashes of fertile particles). The resultant leach liquor is combined with the hull rinse liquid (dilute $\mathrm{HNO}_{3}$, clarified, and adjusted to the proper concentrations of heavy metal $(200-300 \mathrm{~g} / \mathrm{L})$ and nitric acid $(2-3 M)$.

Head-end operations have not been completely developed. Graphite burning generates large amounts of fincly divided solids (soot). Additional development work is required to ensure complete combustion of these small particles. Remote equipment suitable for all of the solids handling and collection requirement would also require development and demonstration.

\subsection{SOLVENT EXTRACTION}

All actinides are recovered so that a nontransuranic fission product waste is produced (Fig. 7.2). Uranium, neptunium, and plutonium are recovered from fissile particle feed solutions by the Purex process ${ }^{3}$ which employs TBP extractant in a normal paraffin hydrocarbon as the solvent phase. The same extraction solvent can be used to also recover thorium when flowsheet conditions are changed to the Thorex process ${ }^{4}$ mode of operation. Purex plants at Hanford and Savannah River have operated satisfactorily with Thorex flow sheets. The HLLW resulting from either Purex or Thorex processes can probably be rendered a nontransuranic waste by using the TRUEX process to co-extract americium (Am) and curium $(\mathrm{Cm})$. The rare carth fission products are also co-extracted along the Am-Cm. Thermal denitration or oxalate precipitation-calcination can be used to convert the solvent extraction product solutions of heavy metal nitrates to their oxides. The nontransuranic (non-TRU) fission product waste solution can be converted to a suitable solid form such as borosilicate glass. 


\subsection{OFF-GAS TREATMENT}

Gaseous species of the radionuclides ${ }^{14} \mathrm{C}\left(t_{1 / 2}=5730\right.$ years $),{ }^{85} \mathrm{Kr}\left(t_{1 / 2}=10.73\right.$ years $)$, and ${ }^{3} \mathrm{H}\left(t_{1 / 2}=12.23\right.$ years) are present in the burner off-gases from HTGR fuel reprocessing. ${ }^{129} \mathrm{I}\left(\mathrm{t}_{1 / 2}=1.59 \times 10^{7}\right.$ years $)$ is present in the ofl-gases from ash dissolution and in trace amounts in burner off-gases. Because of the large quantity of graphite relative to fuel particles, off-gas treatment will require trapping large quantities of $\mathrm{CO}_{2}$.

Various methods for removing $\mathrm{CO}_{2}$ have been considered and experimentally tested to a limited degree. These methods include adsorption in liquid fluorocarbons, molecular sieves, and condensing the $\mathrm{CO}_{2}$ directly and using the liquid $\mathrm{CO}_{2}$ itself as the scrubbing agent. All of these processes produce $\mathrm{CaCO}_{3}$ as the final, solid waste form since a calcium hydroxide scrub cycle is used to convert the $\mathrm{CO}_{2}$ recovered by other means to the carbonate. Various technologies are available for trapping iodine, tritium, and krypton-some of which also trap $\mathrm{CO}_{2}$. These methods have been reviewed by Mailen and Toth. ${ }^{5} \mathrm{CO}_{2}$ treatment technology is discussed by Snider and Kaye ${ }^{6}$ and Davis. ${ }^{7}$

A significant development effort will be required to identify the proper processes for the retention of individual gases, radionuclides, and the sequence (or configuration) in which the processes are deployed. New concepts for increasing net plant confinement factors are discussed by Yarbro, Harrington, and Joy. ${ }^{8}$

\subsection{LIQUID AND SOLID WASTE PROCESSING}

The liquid and solid wastes from solvent extraction processing include the high-level liquid fission product waste, the solvent scrubber waste and waste solvent. Both the HLLW waste and liquid solvent scrubber wastes can be converted to borosilicate glass. Waste solvent is burned along with other plant combustible wastes and the residual ash is incorporated in a cementitous grout or borosilicate glass depending on its TRU content. The SiC hulls and dissolution residues recovered in feed clarification can also be incorporated in borosilicate glass should their TRU content require it. A simple grouting or compaction process might 
be feasible for SiC hulls if they prove to be nontransuranic. The other solid wastes (high efficiency particulate air lilters, rags, wipes, etc.) would be handled in manner identical to conventional LWR fuel reprocessing.

The appropriate treatment processes for converting the trapped fission gases into acceptable waste forms is less clear since these are numerous options for both trapping the gases and then converting them to acceptable form. Croff ${ }^{9,10}$ has reviewed these various conversion options. The treatment processes for iodine may well depend on the process initially used to trap and recover the iodine. Iodine-iaden sorbent materials such as silver zeolites might simply be packaged or they could be incorporated into other materials such as cement, bitumen, or urea-formaldehyde resins. Il iodine is recovered as a relatively pure compound such as barium iodate $\left(\mathrm{BaIO}_{3}\right)$, it can be converted to other solid compounds of iodine, packaged as is, or incorporated in matrix matcrials such as cement. Tritium is recovered in water form and can be incorporated into hydraulic cements by simple processing or by more complex processing into homogeneous, relatively-insoluble, hydrogenous compounds (organic polymers or metal hydrides). Krypton options are more limited since it is inert chemically and storage forms include pressurized cylinders or encapsulation in zeolites. ${ }^{14} \mathrm{C}$ might simply be packaged and stored as $\mathrm{CaCO}_{3}$, the form in which it is recovered. On the other hand, it could be incorporated into other matricess such as grout or concrete prior to packaging.

\subsection{STATUS OF TECHNOLOGY}

A substantial development program wals carricd out more than a decade ago on reprocessing, refabrication and in-pile testing of HTGR luel based on the thorium fuel cycle. ${ }^{11,12}$ All of the essential reprocessing and relabrication operations, including off-gas treatment, were carriced through cold engincering-scalc equipment development and testing. ${ }^{3}$ The development program was carriced out as a collaborative program of GAC and what is now the DOE at facilities of GAC in California and at ORNL. Also, the Germans have carried out a significant effort during the same time period. ${ }^{14}$ 
The general status of the various flow sheet operations are as follows:

- Head end-graphite crushing and burning, particle crushing secondary burning, and ash dissolution have been carriced out in cold enginecring-scale studies. ${ }^{15,16}$ Also some confïrmatory work on burning and ash dissolution has been done on irradiated specimens in small-scale hot cell work. However, problems remain to be solved in developing a satislactory graphite burner and solids handling equipment.

- Solvent extraction-no major developments on Purex or Thorex Process required because operations are not significantly diflerent than have previously been conducted in plant operations. The TRUEX process has only been developed on a laboratory scale. Pilot scale work in hot eells will be required to develop and demonstrate the process.

- Off-gas treatment-methods exist for the removal of the various radioactive gases but development will be required for an integrated treatment system.

A substantial development program would also be required to permit confident design of an efficiently operable, fully remote reprocessing facility. A considerable effort and lead time will be required to develop a plant design and associated data base that meet present day environmental, health, and salety requirements imposed by state and federal agencies.

\subsection{REFERENCES}

1. L. M. Ferris, "Head-End Processes for Graphite Based and Carbide Reactor Fuels," pp 121-170 in Progress in Nuclear Energy Series III: Process Chemistry, Vol. 4, ed., C. E. Stevenson, E. A. Mason, and A. T. Gresky, Pergamon Press, Oxford, 1970.

2. E. P. Horowitz, et al., "The TRUEX Process A Process for the Extraction of Transuranium Elements $\mathrm{rrom}$ Nitric Acid Utilizing Modified Purex Solvent, Solvent Extraction and Ion Exchange," Jommal of Solvent Extraction and Ion Exchange, 3, 75-109 $(1985)$. 
3. J. L. Swanson, "Purex Process Flowsheets," pp. 55-80 in Science and Technology of Tributyl Phosphate Vol III. Applications of Tributyl Phosphate in Nuclear Fuel Reprocessing, ed., W. W. Schulz, L. L. Burger, J. D. Navratil, and K. P. Bender, CRC Press Inc., Boca Raton, Florida, 1990.

4. W. D. Bond, "Thorex Process," Pp. 225-248 in Science and Technology of Tributyl Phosphate, Vol. III. Applications of Tributyl Phosphate in Nuclear Fuel Reprocessing, ed., W. W. Schulz, L. L. Burger, J. D. Navratil, and K. P. Bender, CRC Press Inc. Boca Raton, Florida, 199()$.

5. J. C. Mailen and L. M. Toth, "Chemistry of Volatile Fission Products, in Light Water Reactor Fuel Cycle," pp. 163-190 in The Light-Water Reactor Nuclear Fuel Cycle, ed., R. G. Wymer and B. L. Vondra, CRC Press Inc, Boca Raton, Florida, 1981.

6. J. W. Snider and S. V. Kayce, "Process Behavior and Environmental Assessment of ${ }^{14} \mathrm{C}$ Releases from an HTGR Fuel Reprocessing Facility," in the Proceedings of the ANSAIChE Topical Mecting, Sun Valley, Idaho, August 5-6, 1976.

7. W. Davis, Jr., Carbon-14 Production in Nuclear Reactors, ORNL/NUREG/TM-12, Union Carbide Corporation, Union Carbide Corporation, Oak Ridge National Laboratory, February 1977.

8. O. O. Yarbro, F. E. Harrington, and D. S. Joy, Effluent Control in Fuel Reprocessing Plants, ORNL/TM-3899, Union Carbide Corporation, Oak Ridge National Laboratory, March 1974.

9. A. G. Croff, "Radioactive Waste Management in Light Water Reactor Fuel Cycle," pp. 191-242 in The Light-Water Reactor Nuclear Fuel Cycle, ed., R. G. Wymer and B. L. Vondra, CRC Press Inc., Boca Raton, Floricla, 1981. 
10. A. G. Croff, An Evaluation of Options Relative to the Fixation and Disposal of ${ }^{14} \mathrm{C}$ Contaminated $\mathrm{CO}_{2}$ as $\mathrm{CaCO}_{3}$, ORNL/TM-5171, Union Carbide Corporation, Oak Ridge National Laboratory, April 1976.

11. L. H. Brooks, A. L. Lotts, and R. G. Wymer, "Progress in the Thorium-Uranium 233 Reprocessing Technology," pp. 257-267 in the Proceedings of ANS Topical Meeting on Gas-Cooled Reactors: HTGR and GCFBR, (CONF-740501) May 2-10, 1974.

12. National HTGR Fuel Recycle Development Program Plan, ORNL-4702, Rev. 1, Union Carbide Corporation, Oak Ridge National Laboratory, (August 1973).

13. W. D. Burch and A. L. Lotts, "Developments in Reprocessing Technology for HighTemperature and Fast Brecder Fucls," pp. 673-691, in Proceedings of IAEA International Conference on Nuclear Power and Its Fucl Cycle, Vol. 3, May 2-13, 1977.

14. E. R. Merz, G. Kaiser, and E. Zimmer, "Progress in the Th- ${ }^{233}$ U Recycle Technology," Pp. 268-287 in the Procecdings of ANS Topical Mecting on Gas-Cooled Reactors: HTGR and GCFBR, (CONF-74()5()1), May 2-10, 1974.

15. D. T. Young, Fluidized Combustion for Beds' of Large, Dense Particles in Reprocessing HTGR Fuel, GA-A14327 (March 1977).

16. H. H. Yip, The General Atomic Reprocessing Pilot Plant: Engineering Scale Dissolution System Description, GA-A15298 (April 1979). 


\section{SCHEDULES AND COSTS}

This chapter presents a preliminary evaluation of the schedule and costs for the various options for the disposal of wastes from both existing and future HTGR scenarios. This scoping evaluation is not the result of detailed enginecring studies (feasibility studies, conceptual designs studics) but is based on the authors' experience and a series of assumptions. No attempt is made 10 include any use of HTGRs from the weapons program, but the future HTGR scenario could, most likely, include this possibility. Estimates are made for the cost of development facilitics (capital requirement), operating (annual not including any capital consideration), and the resulting schedule and suitability of the option for the use of the planned LWR repository. The estimates presented in Table 8.1 , are at best $\pm 35 \%$, but should be helpful showing relative costs or in selecting an option to be examined in depth by detailed engineering studies.

The present scenario (now) includes both the FSV and Peach Bottom reactors but does not include any future growth in the use of HTGRs. The future secnario is assumed to be at least an order of magnitude larger than the present seenario and to be ongoing. The present secnario, as defined, would result in disposall of resulting wastes in a 10-year operating period but could be done in less time.

\subsection{DEVELOPMENT COSTS}

Development would address both experimental and paper studies to document the answers to the questions posed in the body of the report, such as;

- combustibility of graphite,

- requirements lor acceptability of wastes in the repository,

- demonstration of the separation of fuel and graphite,

- identification of proper processes and the sequence to be deployed for the separation options requirements such as handling ${ }^{129} \mathrm{I},{ }^{3} \mathrm{H}, \mathrm{Kr}$, and ${ }^{14} \mathrm{C}$. 


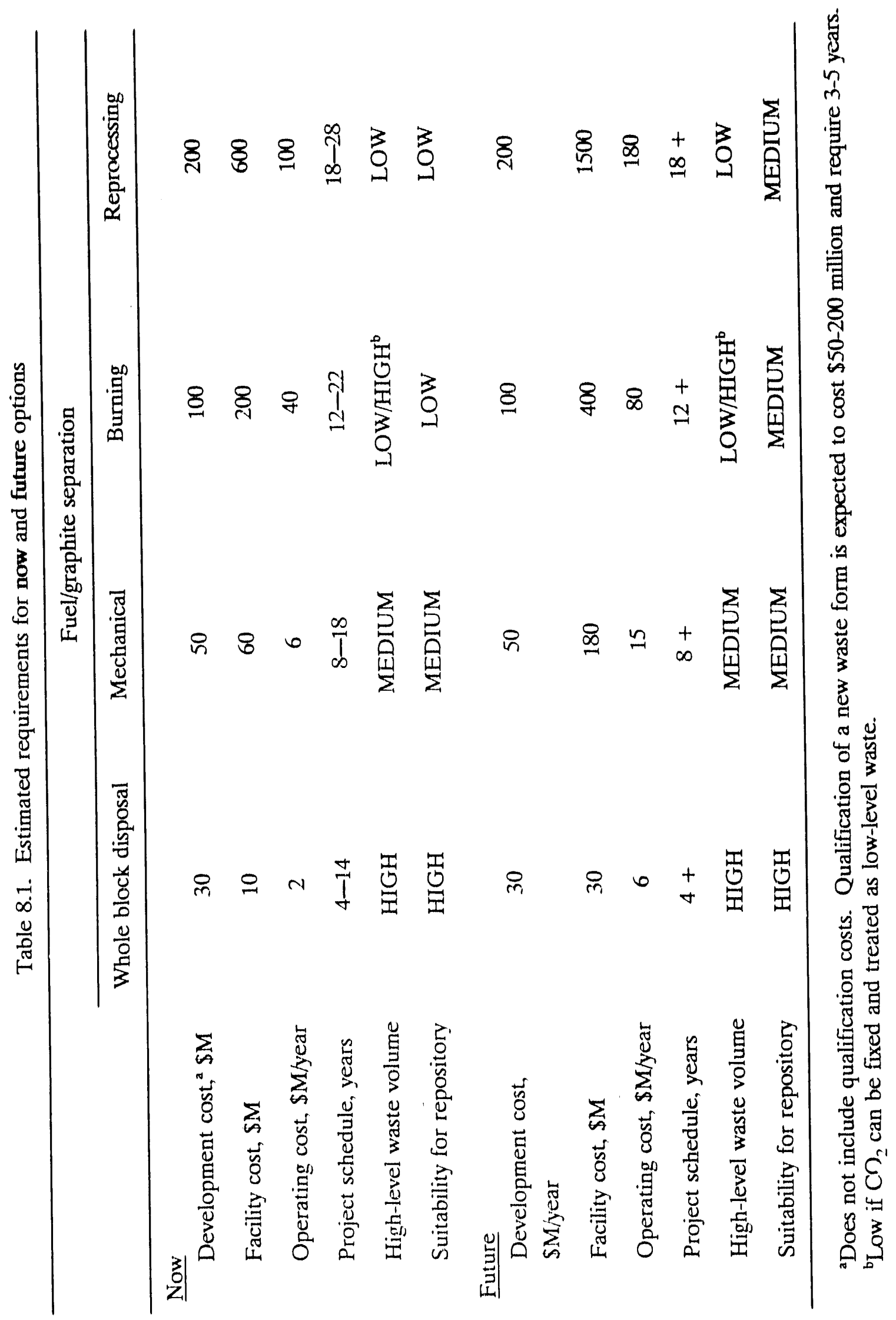




\subsection{CAPITAL COSISS}

The eapital cost estimales for the recuired lacilitles assume:

- For the whole block storage calse, the requirements for suflicient shiclded casks are included, with the cask loading at the reactor site (or at the Idaho Chemical Processing Plant) and unloading/placement all an existing repository site.

- For the scparation casc (option b), an addition of remotely operated "hot cell(s)" to an existing site(s) is assumed. The mechanical suboption may be accomplished in a single "hot cell." The burning suboption is estimated to be two to three times as expensive. The total estimate in both cases includes the cost of shielded casks for shipping.

- For the chemical separation case a new plant is required. The capital cost of plants to process high levels of radioactivity has been studicd revealing a low $\left(\mathrm{e}^{0.15}\right)$ scaling factor. No one would really consider building a chemical separation (reprocessing) plant for use only on cxisting HTGR fuels (approximately 32 M'THM).

The throughput for the present secnario involves just 32 MTHM. A reprocessing plant with a capacity of $15 \mathrm{~kg}$ heavy metal per d could casily handle this material in less than 10 years. Thus, the conceived plant is more like the ORNL's Transuranium Processing Facility in size than it is like a large reprocessing complex. Even if the future scenario is 50 MTHM per year the scale is at least an order of magnitude smaller than existing or planned reprocessing plants.

\subsection{SCHEDULES}

The schedule estimated is the period of time before an option could be operational and the period of operation. The first estimate assumes no delays for nontechnical reasons, which is probably overly optimistic in loday's cnvironment. 


\subsection{OPERATING COSTS}

The operating costs have no provisions for capital considerations (amortization, return on investment, etc.) or operations at the repository. Extrapolations were made based on experience with the operation of radiochemical processing facilitics.

\subsection{SUITABILITY OF WASTE FOR THב REPOSITORY}

Suitability of the option for disposal in the repository is judged at high, low, or medium. It is believed that the resulting waste from all options can be disposed of in the repository and the high estimate for all cases could have been used. However, this report does describe a preliminary evaluation of the practicality of the various options.

Nontechnical issues (and the solution thereof) have not been addressed, such as:

- The stopping or delay of implementation of plans for and even use of completed facilities, (i.e., the governor of Idaho blocking the receipt of further FSV at ine completed convection-cooled facility at ICPP).

- The myriad new oversight and regulatory organizations and the resulting effect on cost and schedule. Some consideration has been given to this item, but only the future will prove just how high the costs and how long the schedules will become.

It is clear that if schedule and cost rule for the present option whole block storage will be selected. It will also be selected for the future if the comparison does not include repository costs. The evaluation of final waste disposal costs, whether repository or other are beyond the scope of this study. Use of the chemical separation option assumes a market for the recovered fissile material in the fuel cycle for power reactors. At present, this market is a dream, but surely use of recovered fissile material in power reactors is both desirable and technically feasible. 


\section{CONCLUSIONS}

HTGR fuel is markedly different from the common fiuel, that of LWR that will be placed in a repositery. Several options are available for disposal of HTGR spent fuel: 1) whole block disposal, 2) disposal after separalion of' gruphite and spent fuel, and 3) disposal after rather complete chemical processing.

It is technically feasible to consider all of the options at this time; that is, there are sufficient data and information to indicate that all of them can be accomplished from a process pointof-view. What is not known in ench case is the exact performance capability of the resultant waste forms. From the standpoint of process cost and schedule (not considering repository cost or value of lued that might be recyeled), the options must be ranked as follows in order of increased eost and longer schedule to pertorm the option: 1) whole block, 2a) physical separation, 2b) chemical separation, and 3) complete chemical processing.

\subsection{CONCLUSIONS ON WHOLE BLOCK HTGR SPENT FUEL DISPOSAL}

The most direct, perhaps the most saltisfiatory, and certainly the least expensive option (if repository volume costs are not considered), is to dispose of the fuel as whole blocks, in which case the luel will be encased in massive quantitics of graphite. No processing is required for this option. Rescarch by the Germans indicate that the "as irradiated" fuel element is suitable as a waste form for a salt repository. Scoping calculations were conducted on the behavior of HTGR luel elements under oxidizing repository conditions as would be expected at Yucea Mounlain.

The following are preliminary conclusions from consideration of the whole block option:

- Whole block HTGR spent fuel will meet regulatory waste aceptance criteria for a repository. 
- The projected performance of whole block HTGR spent fuel is significantly better than LWR spent fuel.

- The available information suggests that the HTGR fucl assembly may be a superior waste form with repository performance characteristics significantly better than conventional waste forms.

- The very high performance is a result of the graphite block; thus, there are major incentives from the perspective of performance in the repository to nct separate the fuel from the graphite.

- The whole block disposal option does have the disadvantage of requiring a high volume of repository space per unit of heavy metal in the spent fuel because of the volume of graphite inherent in HTGR fuel designs. However, larger waste containers and alternate emplacement strategics may mitigate the cost impact associated with the larger volume.

\subsection{CONCLUSIONS ON DISPOSAL AFTER SEPARATION OF GRAPHITE AND SPENT FUEL}

A second option requires the separation of the fuel from the graphite, by physical means or by burning. In either case, disposal of the remaining graphite or the "fixed" ${ }^{14} \mathrm{C}$ remains a problem that can be solved technically. However, the option is considerably more expensive and may not be more desirable from an environmental point-of-view than the whole block option. Some development work is required to implement this option.

Preliminary conslusions concerning the option of disposal after separation of the graphite from the spent fuel follow:

- It is feasibie 10 separale by physical technipues, such as simply pushing the fuel rods out of the fuel block or by mechanical means such as crushing and screening, but it is not known how eifieicen! (i e, clean) the separation will be. 
- It is feasible to separate by burning, cither whole fuel elements or crushed fuel elements, with effective partitioning of the particles of pert fucl and with effective processing of the gaseous products.

- In the case of burning, if the $\mathrm{CO}_{2}$ must be fixed as $\mathrm{CaCO}_{3}$, the volume of waste will be increased significantly over the volume of the original fuel elements or separated graphite blocks.

- The products of either burning or physical separation that contain the bulk carbon may be sufficiently low in radialion level to qualify for disposal as low level radioactive waste, but this cannot be proven at this time on the basis of existing information.

- This method may be more attractive for future spent fuel elements that have been designed for physical separation of bulk graphite from the spent fuel, and there may be methods to enhance this possibility.

- This option has the advantage of occupying less volume for high level waste disposal, but it may be necessary to encase the spent fuel in some type of matrix.

\subsection{CONCLUSIONS ON DISPOSAL WITH DISSOLUTION OF FUEL}

The third option requires separation of the luel and solvent extraction to separate waste and fuel components of the spent fucl. Probably the only time this option will be used is when it is desirable to recover the fuel for recycling. While it is technically feasible to utilize this option, substantial development must be clone before facilities can be designed and operated for this option.

Conclusions regarding this option follow:

- Technology has been demonstrated at suffieient scale and depth to give confidence that this option could be employued 
- Because of the fact that the process flow sheets must be demonstrated at pilot or prototypical scale with irradiated fuel and extensive facilities are required for production capability, this option should be considered only for cases involving substantial future deployment of HTGRs with recycle of fuel.

- Technology is available for handling the waste streams and for placing them in suitable forms for disposal.

The assessments and analyses of this report that deal with the performance of HTGR spent fuel in a HLW repository were prepared in the absence of a Yucca Mountain site-specific performance assessment. When such an assessment is issued, the issue of HTGR spent fuel disposal may need to be re-evaluated. 
Appendix A. DETAILS OF FORT ST. VRAIN FUEL 


\title{
APPENDIX A: DETAILS OF FT. ST. VRAIN FUEL
}

\section{A.1 GRAPHITE}

The additional details of FSV fuel included in this appendix came from two of the principal sources of information for Sect. 3.,2

The $\mathrm{H}$ series graphites have these specifications on impurities:

$\begin{array}{lr}\text { boron } & 5 \mathrm{ppm} \\ \text { iron } & 100 \mathrm{ppm} \\ \text { vanadium plus } & \\ \text { titanium } & 100 \mathrm{ppm} \\ \text { nitrogen (est.) } & 25 \mathrm{ppm} \\ \text { total ash } & 1000 \mathrm{ppm}\end{array}$

\section{A.2. VARIATION IN DESIGN OF FUEL BLOCKS}

In addition to the standard fuel block shown in Fig. 3.1, there are eight variants for specialized functions:

\author{
control fuel block, \\ bottom control fuel block, \\ neutron souree block, \\ standard block with enlarged handling hole, \\ control block with enlarged handling hole, \\ bottom control block with enlarged handling hole, \\ fuel test blocks, and \\ californium neutron source block.
}


All of these variants have the same overall configuration and differ only in some specific detail. The most obvious difference is in the control blocks, which have three large holes for the insertion cidontrol rods (Fig. A.1.). The next most obvious difference is in the bottom blocks, whereffie fuel does not extend the whole length of the block.

\section{A.3. FUEL STICK IMPURITY SPECIFICATIONS}

The impurity specifications for the fuel rods are:

$\begin{array}{lc}\text { iron } & <500 \mathrm{ppm} \\ \text { sulfur } & <1200 \mathrm{ppm} \\ \text { titanium } & <50 \mathrm{ppm} \\ \text { vanadium } & <50 \mathrm{ppm} \\ \text { hydrogen } & <200 \mathrm{ppm} \\ \text { residual ash } & <300 \mathrm{ppm}\left(\text { at } 900^{\circ} \mathrm{C}\right) \\ \text { water } & <400 \mathrm{ppm} \\ \text { nitrogen (est.) } & 25 \mathrm{ppm} \\ \text { total boron equivalent } & 5 \mathrm{ppm}\end{array}$

\section{A.4. WEIGHTS OF FUEL BLOCKS AND COMPONENTS}

Table A.1 gives the total weights of various fuel block types, and also the weights of the primary components, namely, the graphite block body, fuel rods, and poison rods.

\section{A.5. RESULTS OF BURNUP CALCULATIONS}

The results of burnup calculations for the luel elements in three discharged core segments are stored on floppy disks in the format shown in Table A. 2 for a representative fuel block. In order to establish the accuracy of the calculated values for burnup, measured and calculated average values for surveillance element 1-1773 were compared by GAC, using three different calculational methods. The calculated vaules were somewhat lower 


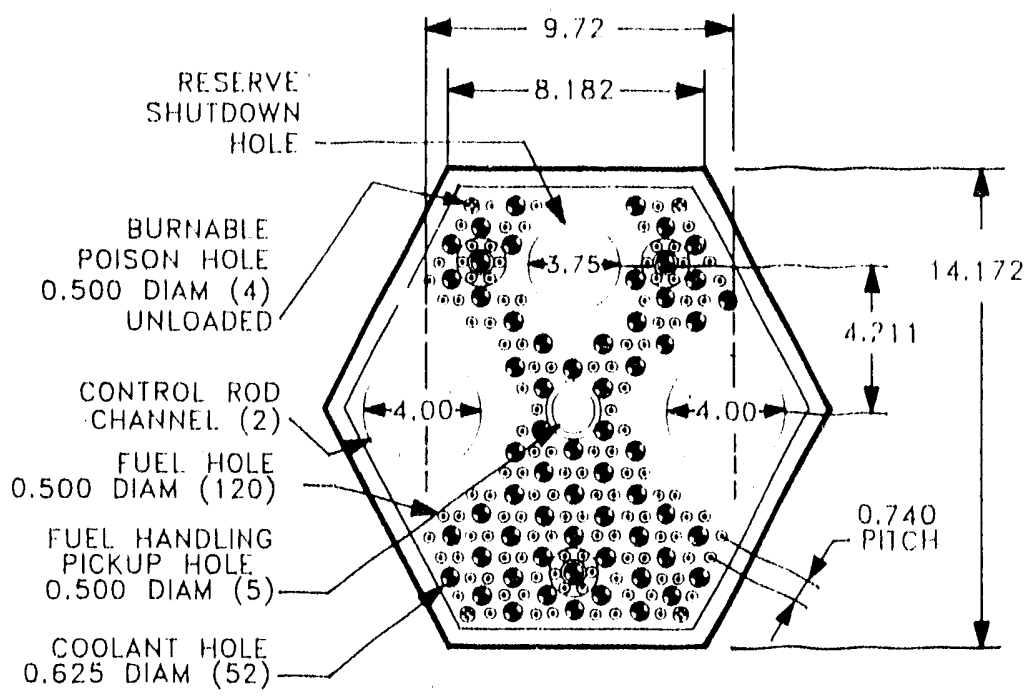

ORIII INWG 91A.927

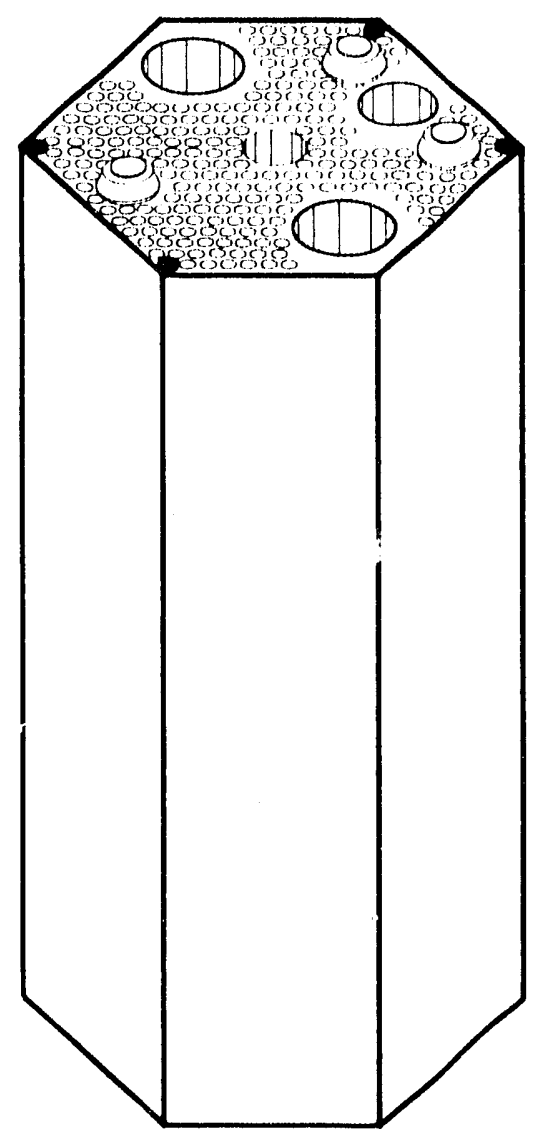

HOTF: ALL. DIMENISIONS ARE IN INCHES.

Fig. A.1. Control fuel elements and surveillance control element: 
Table A.1. FSV fucl element component weights ${ }^{\mathrm{a}}$

\section{Elcment Total Weights}

Element type

Standard

Surveillance

Neutron source

Californium neutron source

Test

Bottom control

Control

Surveillance control
Weight

$128 \mathrm{~kg}$

$128 \mathrm{~kg}$

$128 \mathrm{~kg}$

$128 \mathrm{~kg}$

$126 \mathrm{~kg}$

$111 \mathrm{~kg}$

$109 \mathrm{~kg}$

$109 \mathrm{~kg}$

\section{Component Weights}

Graphite body:

Regular fuel block

$86 \mathrm{~kg}$

Control rod fucl block

$85 \mathrm{~kg}$

Bottom control rod fucl block

$94 \mathrm{~kg}$

Fuel rod ${ }^{b}$

Thorium

$4.2 \mathrm{~g}$

Uranium

$0.2 \mathrm{~g}$

Silicon

$1.3 \mathrm{~g}$

Coatings

$6.4 \mathrm{~g}$

Matrix

$1.3 \mathrm{~g}$

Poison rod (boron carbide)

$100 \mathrm{~g}$

\section{AAll weights are approximate.}

This is for an individual fuel rod, which is about $1.25-\mathrm{cm}(0.5-\mathrm{in}$.) diameter by $7.6 \mathrm{~cm}$ (3-in.) long. (NOTE: This is an early luel stick design. The length was subsequently shortened to $2 \mathrm{in}$. because of warpage in the longer length.) 
Table A.2. Simple ol fuel accountability data

\begin{tabular}{|c|c|c|}
\hline \multirow{2}{*}{$\begin{array}{l}\text { Serial Number: } 1-1773 \\
\text { Core location: Region } 18 \text {, Column 7, layer } 7\end{array}$} & \multicolumn{2}{|c|}{ Accountability date: $3 / 31 / 86$} \\
\hline & \multicolumn{2}{|c|}{ Hcavy metal wcights (g) } \\
\hline Nuclide & Inilia! & Current \\
\hline$\sqrt{212} \mathrm{Th}$ & $8,3.31 .77$ & $8,056,46$ \\
\hline${ }^{231} \mathrm{~Pa}$ & ()() & .03 \\
\hline${ }^{212} \mathrm{U}$ &.$(0)$ & .93 \\
\hline${ }^{233} \mathrm{U}^{\prime \prime}$ & (6) & $152: 8$ \\
\hline${ }^{21} \cdot 1 \mathrm{U}$ & .0() & 14.19 \\
\hline${ }^{231} \mathrm{U}$ &.$(0)$ & 1.58 \\
\hline${ }^{236} \mathrm{U}$ & () & .10 \\
\hline \multicolumn{3}{|l|}{ Fissile Particles } \\
\hline${ }^{272} \mathrm{Th}$ & $1,8.32 .23$ & $1,771.69$ \\
\hline${ }^{231} \mathrm{~Pa}$ &.$(0)$ & .01 \\
\hline${ }^{212} \mathrm{U}$ & .00 & .01 \\
\hline${ }^{233} U^{a}$ & .00 & 33.60 \\
\hline${ }^{234} U$ & 3.24 & 5.30 \\
\hline${ }^{2 \cdot 35} \mathrm{U}$ & $4(07 .(1) 7$ & 123.40 \\
\hline${ }^{236} \mathrm{U}$ & 1.24 & 49.72 \\
\hline${ }^{218} \mathrm{U}$ & 25.46 & 22.58 \\
\hline${ }^{217} \mathrm{~Np}$ &.$(0)$ & 3.44 \\
\hline${ }^{218} \mathrm{Pu}$ &.$(0)$ & .72 \\
\hline${ }^{239} \mathrm{Pu}$ & .0() & .54 \\
\hline${ }^{240} \mathrm{Pu}$ & .00 & .24 \\
\hline${ }^{241} \mathrm{Pu}$ & $.00)$ & .20 \\
\hline${ }^{24} 2 \mathrm{Pu}$ & & .0013 \\
\hline Total & $10,6(01.00$ & $10,236.76$ \\
\hline Total fissile uranium & 407.07 & 311.36 \\
\hline Total uranium & $4.37 .(0)$ & 403.29 \\
\hline Total fissile plutonium &.()() & .75 \\
\hline Total plutonium &.() & 1.85 \\
\hline Effective ${ }^{233} \mathrm{U}$ enrichment & .00 & $46.21 \%$ \\
\hline Effective ${ }^{23.5} \mathrm{U}$ enrichment & $93.15 \%$ & $30.99 \%$ \\
\hline${ }_{232} \mathrm{IJ}$ & .00 & $9(0.79 \mathrm{ppm}$ \\
\hline Fertile particle fima ${ }^{c}$ & .00 & $1.29 \%$ \\
\hline Fissile particle fima &.()() & $11.27 \%$ \\
\hline Burnup (MWd/MT) & & $32,601.50$ \\
\hline Cumulative EFPD & & 657.30 \\
\hline
\end{tabular}

${ }^{2}$ Includes full decay of ${ }^{23} \mathrm{~Pa}$.

'Includes full decay of ${ }^{2 \cdot 19} \mathrm{~Np}$.

'Fission per Initial Metal Alom

"Equivalent Full Power Days 
(4 to $18 \%$ ) than the measured values. A compatison of measured and calculated uranium isotopic concentrations for the same surveillance element (1-1773) was also done. The ${ }^{234} \mathrm{U}$ and ${ }^{235} \mathrm{U}$ concentrations are slightly lower than predicted, while the ${ }^{236} \mathrm{U}$ and ${ }^{238} \mathrm{U}$ concentrations are higher than predicted. The ${ }^{233} \mathrm{U}$ concentration was not reported.

\section{A.6 RADIOLOGICAL CHARACIERISTICS AND THERMAL POWER}

The radiological characteristics of average FSV fucl irradiated to $100,000 \mathrm{MWd} / \mathrm{Mt}$ have been calculated for various decay times ranging from 120 days to 1 million years. The planned equilibrium burnup was $100,000 \mathrm{MWd} / \mathrm{MTIHM}$. The calculated radioactivity for selected nuclides as a function ol time is shown in Table A.3; the calculated thermal power is given in Fig. A.2. The "bump" all $10^{4} 1010^{5}$ years is due to the decay daughters of ${ }^{233} \mathrm{U}$ in the fertile particles. For luels with less burnup, acecptable first approximations of radioactivity and thermal power can be oblained by using linear interpolation from the values at $100,000 \mathrm{MWd} / \mathrm{MTIHM}$. For transuranic content, linear interpolation will give a conservative (i.e., too high) result.

For repository disposal, thermal output is a controlling parameter. The thermal power of FSV fuel can be estimated from Fig. A.2. At 10 years decay time, for example, the thermal output per MTIHM (i.e., U plus Th) is about $3400 \mathrm{~W}$. Since one fuel element contains $10 \mathrm{~kg}$ of heavy metal, the thermal power per full-burnup block would be about $34 \mathrm{~W}$. However, the maximum burnup achieved is only half of the planned maximum, and the average is closer to one-third, or $11 \mathrm{~W}$. Allowing for the $10 \%$ discrepancy between calculated and measured values of burnup, a value of about $12 \mathrm{~W}$ per FSV element is obtained. At 5 y ars cooling, the value would be roughly twice as much. For future HTGR fuel, full burnup should be assumed, or $35 \mathrm{~W}$ per element after 10 years cooling, or $70 \mathrm{~W}$ per element after only 5 years. 


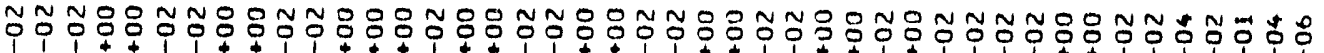

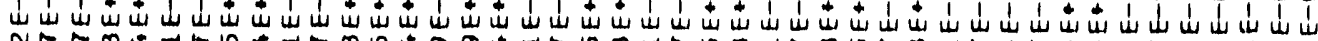

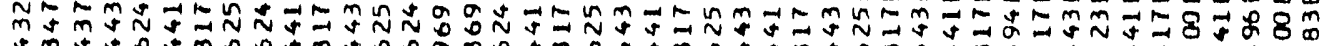

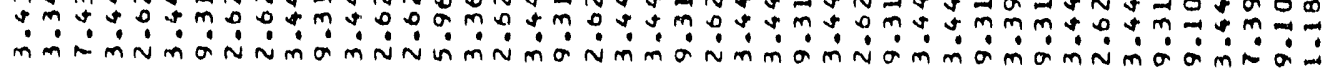

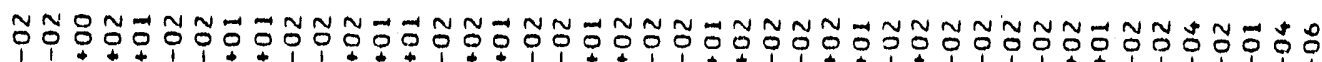

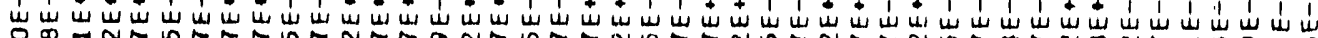

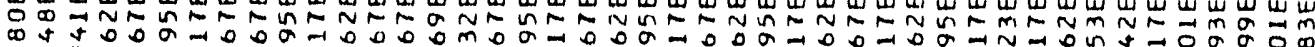

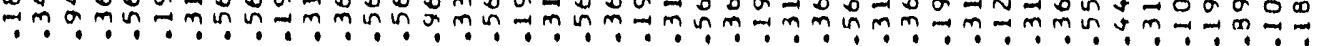

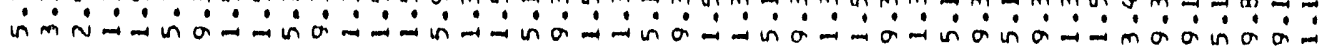

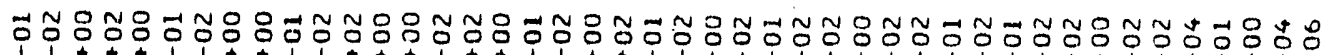

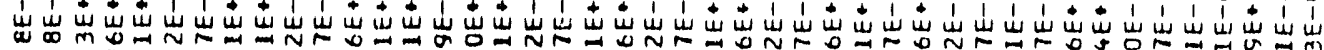

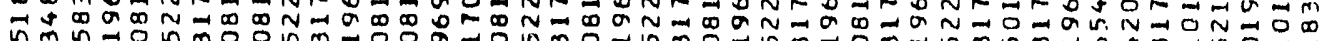
nm $n$.

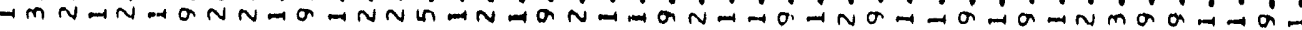

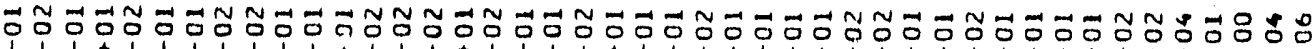

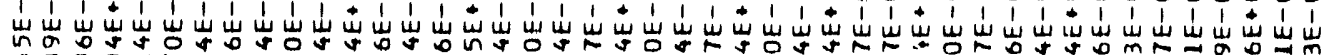

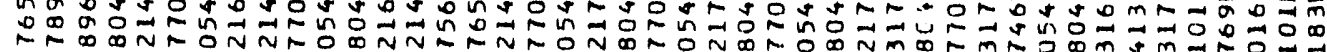

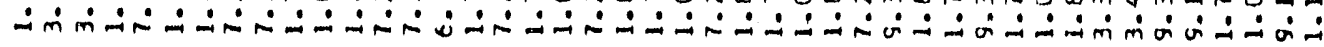

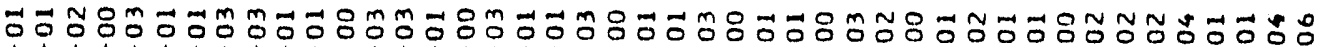

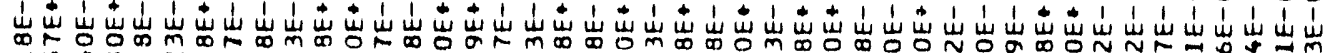

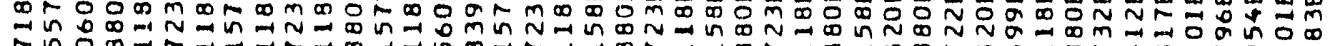

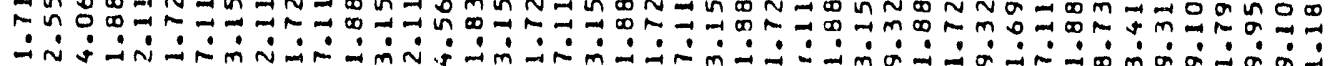

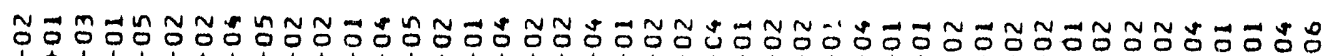

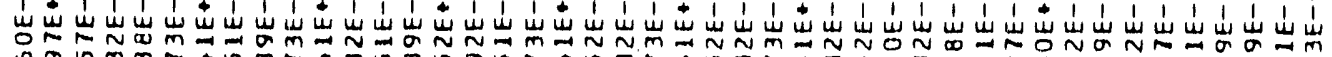

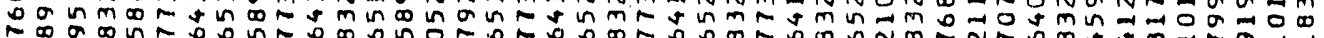

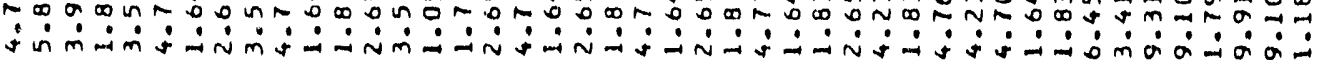

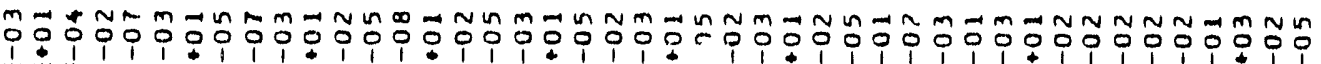

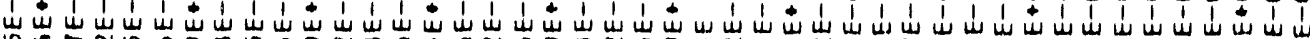

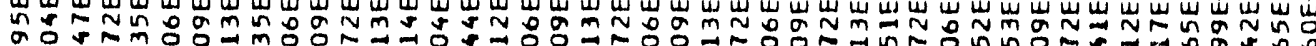

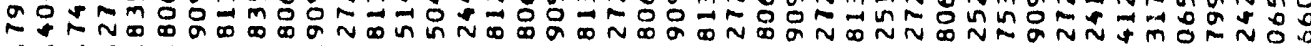

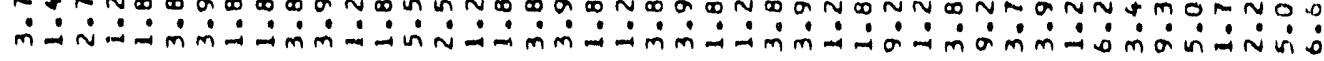
00000000000000000000000000 N00 000 N000 N0

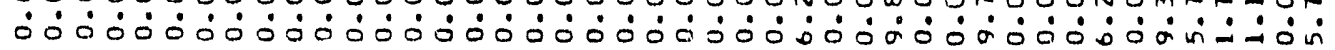




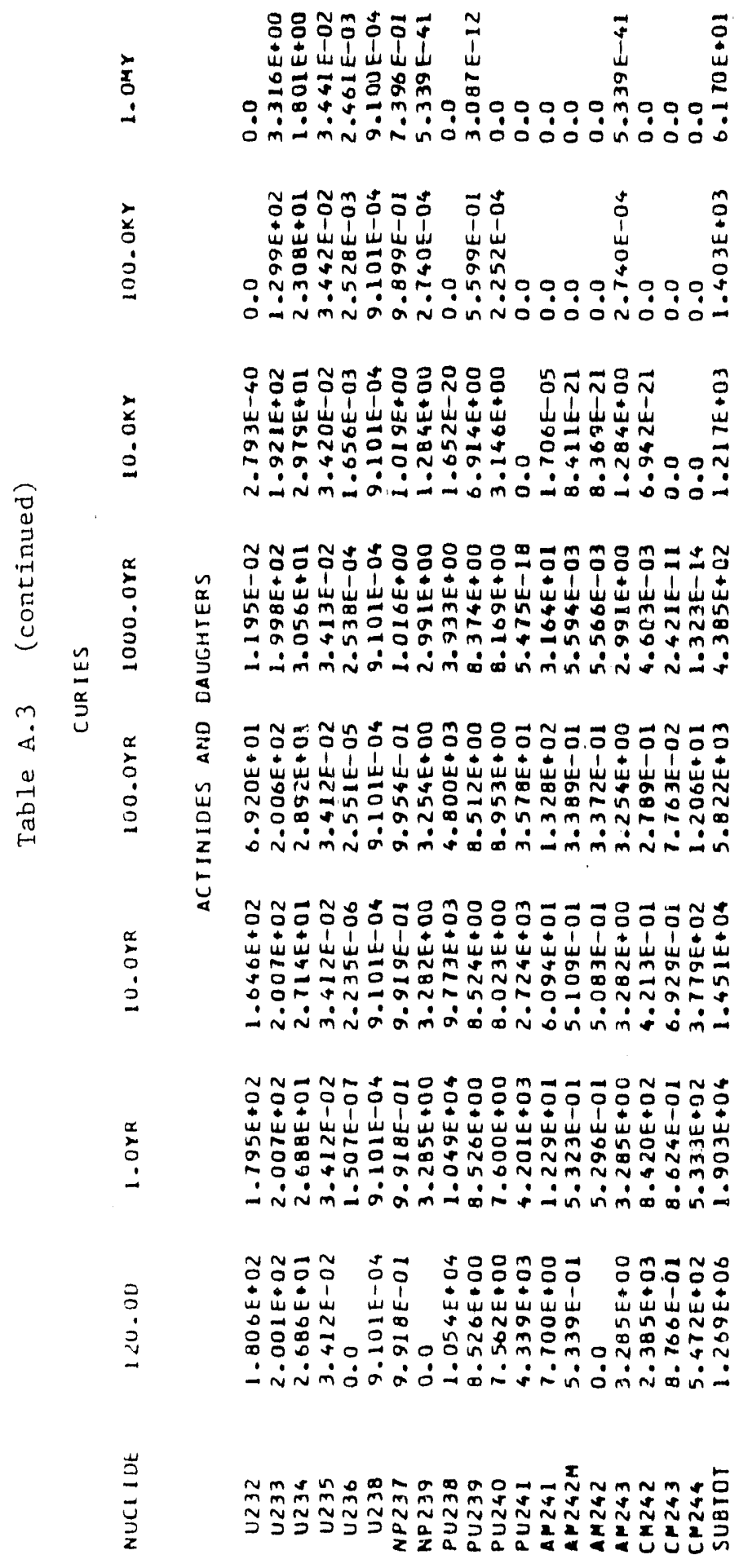

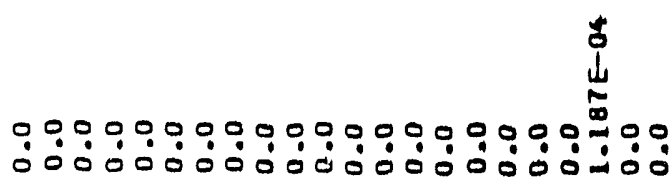

耑

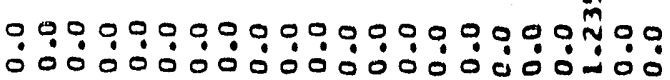

0000000000000000000 N

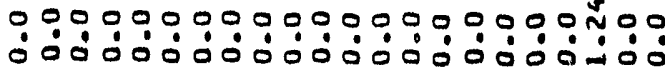

* กั ถ

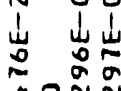

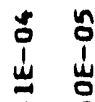

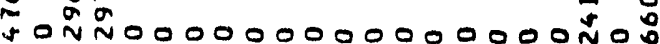

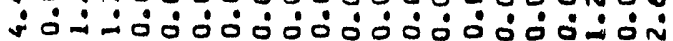

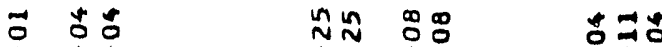

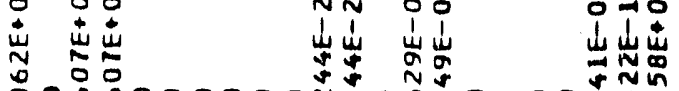
:0:0000000 N0 N

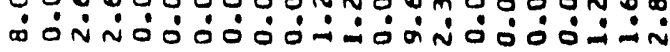

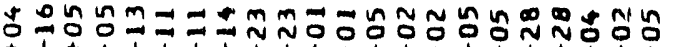

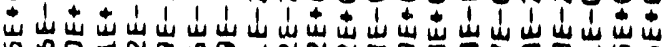

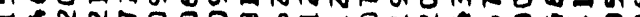
政N

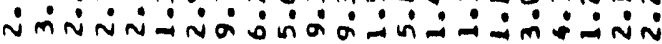

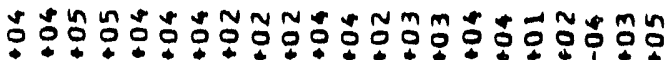

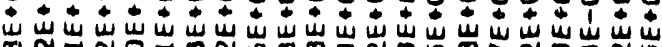

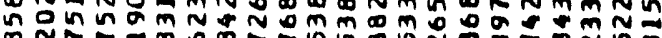

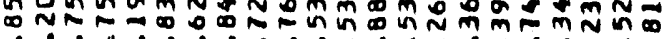

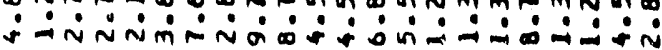

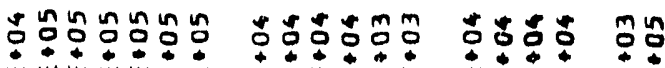

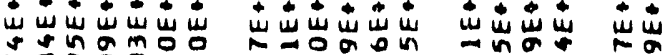

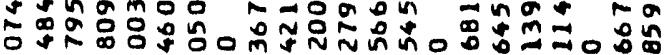

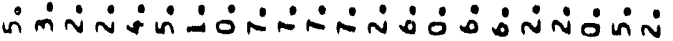

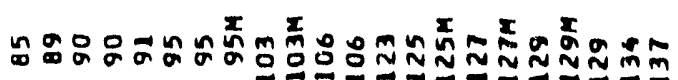

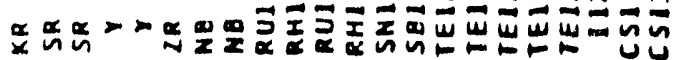




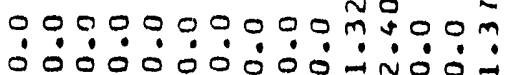

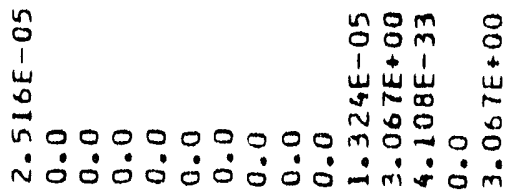

+ $\quad m m$ mm

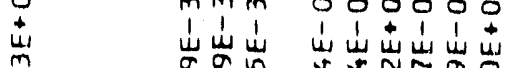
c

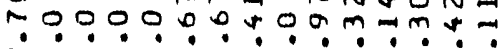

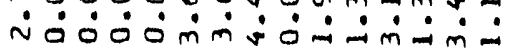

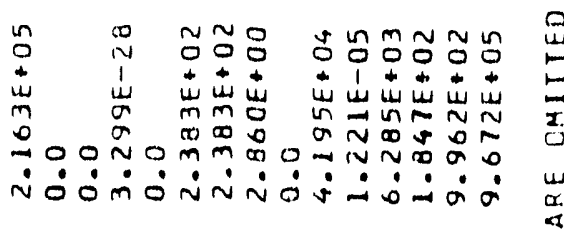
นn $t$
4

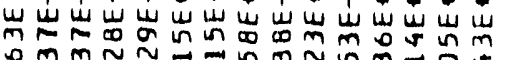

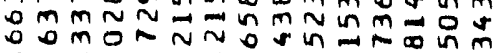

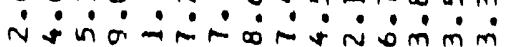


88

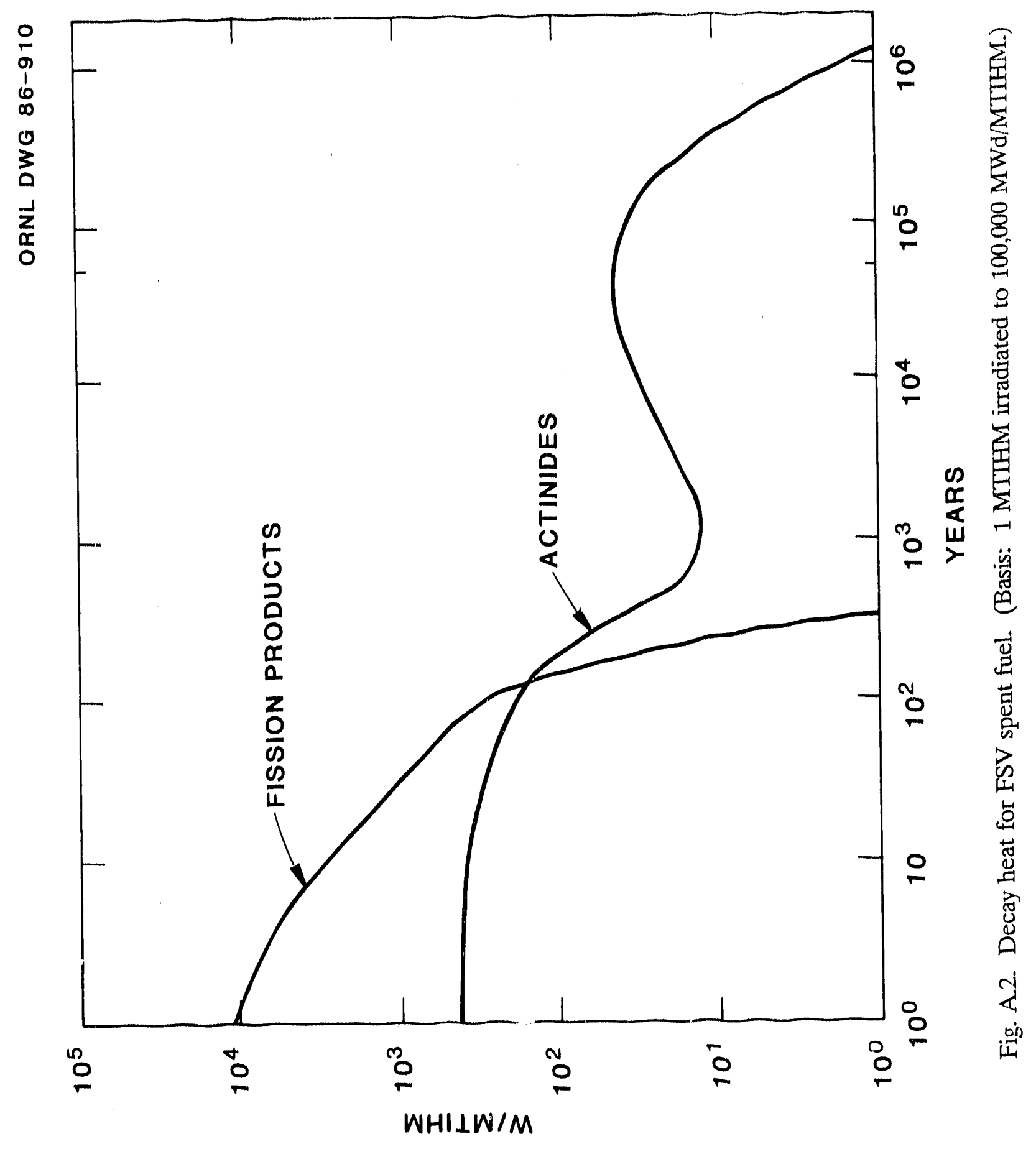




\section{A.7 REFERENCES}

1. U.S. Department of Energy, Characteristics of Spent Fuel, High-Level Waste, and Other Radioactive Wastes Which May Require Long-Term Isolation, DOE/RW-0184, Vols. 1-6 (December 1976) Vol. 7-8 (June 1988).

2. Morissette, R. P., and Tomsio, N., Characterization of Fort St. Vrain Fuel, ORNL/SUB86022047/1 (Oct. 1986). 
Appendix B. OXIDATION OF URANIUM OXIDE 


\section{APPENDIX B: OXIDATION OF URANIUM DIOXIDE}

The U-O system is rather complex and has been studied extensively. It is well known that $\mathrm{UO}_{2}$ oxidizes at low temperatures, with measurable rates in the temperature regime expected for a future repository. In fact, maintaining $\mathrm{UO}_{2}$ in a stoichiometric condition is quite difficult, even at ambient temperature.

$\mathrm{UO}_{2}$ follows this oxidation sequence (with one exception, which is temperature dependent):

Surface oxidation to $\mathrm{UO}_{2+}$

Bulk oxidation to $\mathrm{UO}_{2+}$

Bulk oxidation to $\mathrm{U}_{4} \mathrm{O}_{9}$

Bulk sxidation to $\mathrm{U}_{3} \mathrm{O}_{7}$

Bulk oxidation to $\mathrm{U}_{3} \mathrm{O}_{8}$

Bulk oxidation to $\mathrm{UO}_{3}$

The $\mathrm{UO}_{2+}$ phase is a solid solution with the added oxygens placed interstitially within the cubic $\mathrm{UO}_{2+}$ structure. Since this represents an increase in the positive valence of the uranium, the lattice contracts slightly. This contraction opens up the grain boundaries, thus enhancing the diffusion of oxygen between the grains and into the bulk structure. The $\mathrm{U}_{4} \mathrm{O}_{9}$ phase, which is a line compound, may be viewed as the limiting composition of interstitial oxygen within a cubic structure and is the most dense oxide of uranium.

The $\mathrm{U}_{3} \mathrm{O}_{7}$ phase, which is also a line compound, has a tetragonal structure and forms next, but only at temperatures below about 35()$^{\circ} \mathrm{C}$. Above that temperature, orthogonal $\mathrm{U}_{3} \mathrm{O}_{8}$ forms from $\mathrm{U}_{4} \mathrm{O}_{4}$. Any $\mathrm{U}_{3} \mathrm{O}_{7}$ formed at lower temperature, if heated above its transition temperature, disproportionates $10 \mathrm{U}_{4} \mathrm{O}_{9}$ and $\mathrm{U}_{3} \mathrm{O}_{8}$. The $\mathrm{U}_{3} \mathrm{O}_{8}$ phase has a composition range that is temperature dependent, but nominally spans $\mathrm{UO}_{2.56}$ to $\mathrm{UO}_{2.67}$.

Oxidation beyond $\mathrm{U}_{3} \mathrm{O}_{8}$ to $\mathrm{UO}_{3}$ dees nof occur spontaneously in dry air, but does occur if moisture is present, yiclding a hydrated $\cup_{3}$. Oxidation of $\mathrm{UO}_{2}$ to $\mathrm{U}_{4} \mathrm{O}_{9}, \mathrm{U}_{3} \mathrm{O}_{7}$, or $\mathrm{U}_{3} \mathrm{O}_{8}$ is 
apparently unaffected by moisture, although there is not complete agreement on this observation.

The phase sequence that occurs in oxidation is reversed when $\mathrm{UO}_{3}$ is reduced with hydrogen. ${ }^{1,2}$ The two sets of studies-oxidation and reduction-thus corroborate each other, but reduction requires higher temperatures than oxidation.

A score or more of excellent studies of $\mathrm{UO}_{2}$ oxidation have been published, covering a wide range of temperature. A sampling is listed here:

Low Temperature $\left(-130\right.$ to $\left.50^{\circ} \mathrm{C}\right)$ :

Anderson, et al. ref. 3

Medium Temperature $\left(100\right.$ to $\left.360^{\circ} \mathrm{C}\right)$ :

Aronson, et al.

Blackburn, et al.

Hoekstra, et al.

Walker

Woodley, et al ref. 4

ref. 5

ref. 6

ref. 7

ref. 8

High Temperature $\left(200\right.$ to $\left.1000^{\circ} \mathrm{C}\right)$ :

De Marco, et al.

Peakall and Antill

Scolt and Harrison ref. 9

ref. 10

ref. 11

The oxidation study of greatest interest 10 the present evaluations is the one done at Hanford by Woodley, Einziger, and Buchanan. ${ }^{8}$ They addressed directly the oxidation of spent (i.e., irradiated) LWR fucl, as taken from the fuel pins of 'Tur', ay Point fuel in its usual post-irradiated, fragmented condition. They measured the rate of oxidation at temperatures between 140 and $225^{\circ} \mathrm{C}$ in air atmospheres both wet (dew point of $14.5^{\circ} \mathrm{C}$ ) and dry (dew point of $\left.-70^{\circ} \mathrm{C}\right)$. They expressed the temperalure dependence in terms of the activation energy, for which they obtained a value of $27 \pm 4 \mathrm{kcal} / \mathrm{mole}$. This is in the upper range of a diffusion controlled process. Other investigators found similar alues for the activation energy: 
Aronson, et al.

Blackburn, et al.

Walker

Scott \& Harrison
$26.3 \mathrm{kcal} / \mathrm{mol}$

19.1 ref. 4

ref. 5

ref. 7

ref. 11

For a very high surface area $\mathrm{UO}_{2}$, Walker found $32.2 \mathrm{kcal} / \mathrm{mole}$ for the activation energy. This probably reflects less diffusion control in the smaller particles.

The Hanford study was done in terms of weight gain per 200-mg sample and is directly applicable to the present analysis, since there is a one-to-one analogy between the study samples and the irradiated fuel in LWR spent fuel. In addition, the temperature range used is close to the projected cask surface temperature in a repository, and requires only a short extrapolation from 140 to $100^{\circ} \mathrm{C}$. Over the time/temperature range studied, oxidation usually slowed drastically as the $\mathrm{U}_{3} \mathrm{O}_{7}$ composition was approached. Therefore, they expressed their rate results as fraction converted to $\mathrm{U}_{3} \mathrm{O}_{7}$ since the $\mathrm{U}_{3} \mathrm{O}_{7}$ composition was the effective upper limit of oxidation in their study. They found no effect from moisture, over a wide range of partial pressure of water. This suggests that oxygen is sorbed much stronger than water on the surface of $\mathrm{UO}_{2+}$ and $\mathrm{U}_{4} \mathrm{O}_{9}$.

Table B.1 lists rate data based on ref. 8. The "times to completion" values were based on the data presented at the first five listed temperatures. The reciprocal of the times is a rate which, when divided into $100 \mathrm{~h}$, gives the traction of $\mathrm{UO}_{2}$ converted to $\mathrm{U}_{3} \mathrm{O}_{7}$ in $100 \mathrm{~h}$. These rates were plotted in Fig. B.1 and extrapolated to $100^{\circ} \mathrm{C}$, giving the value listed in Table B.1 for that temperature.

From these data, it is possible to estimate the rate of oxygen uptake by LWR spent fuel in a repository, and also the capacity (or sink) for oxygen from this reaction. A future repository is projected to contain 7(),000) MT of uranium, as the dioxide. Complete oxidation of this to $\mathrm{U}_{3} \mathrm{O}_{7}$ (or $\mathrm{UO}_{2.33}$ ) would then require $0.33 \mathrm{~mol}$ of oxygen (i.e., $0.165 \mathrm{~mol} \mathrm{of} \mathrm{O}_{2}$ ) per mol of uranium: 
TABLE B.1. Oxidation Rate of $\mathrm{UO}_{2}$ to $\mathrm{U}_{3} \mathrm{O}_{7}$

\begin{tabular}{ccc} 
Temp, ${ }^{\circ} \mathrm{C}$ & Time to Completion, $\mathrm{h}^{\mathrm{a}}$ & $\begin{array}{c}\text { Rate, fraction } \\
\text { converted } \\
\text { per } 100 \mathrm{~h}\end{array}$ \\
\hline 225 & 350 & 0.286 \\
200 & 800 & 0.125 \\
175 & 3,000 & 0.033 \\
175 & 5,200 & 0.019 \\
140 & 14,000 & 0.007 \\
$100^{\mathrm{b}}$ & Not measured & $0.0015^{\mathrm{b}}$
\end{tabular}

\footnotetext{
'Based on R. E. Woodley, R. E. Einziger and H. C. Buchanan, Nucl. Technol. 85, 74-88, (April 1989).

${ }^{b}$ Extrapolated from Fig. B.1.
} 


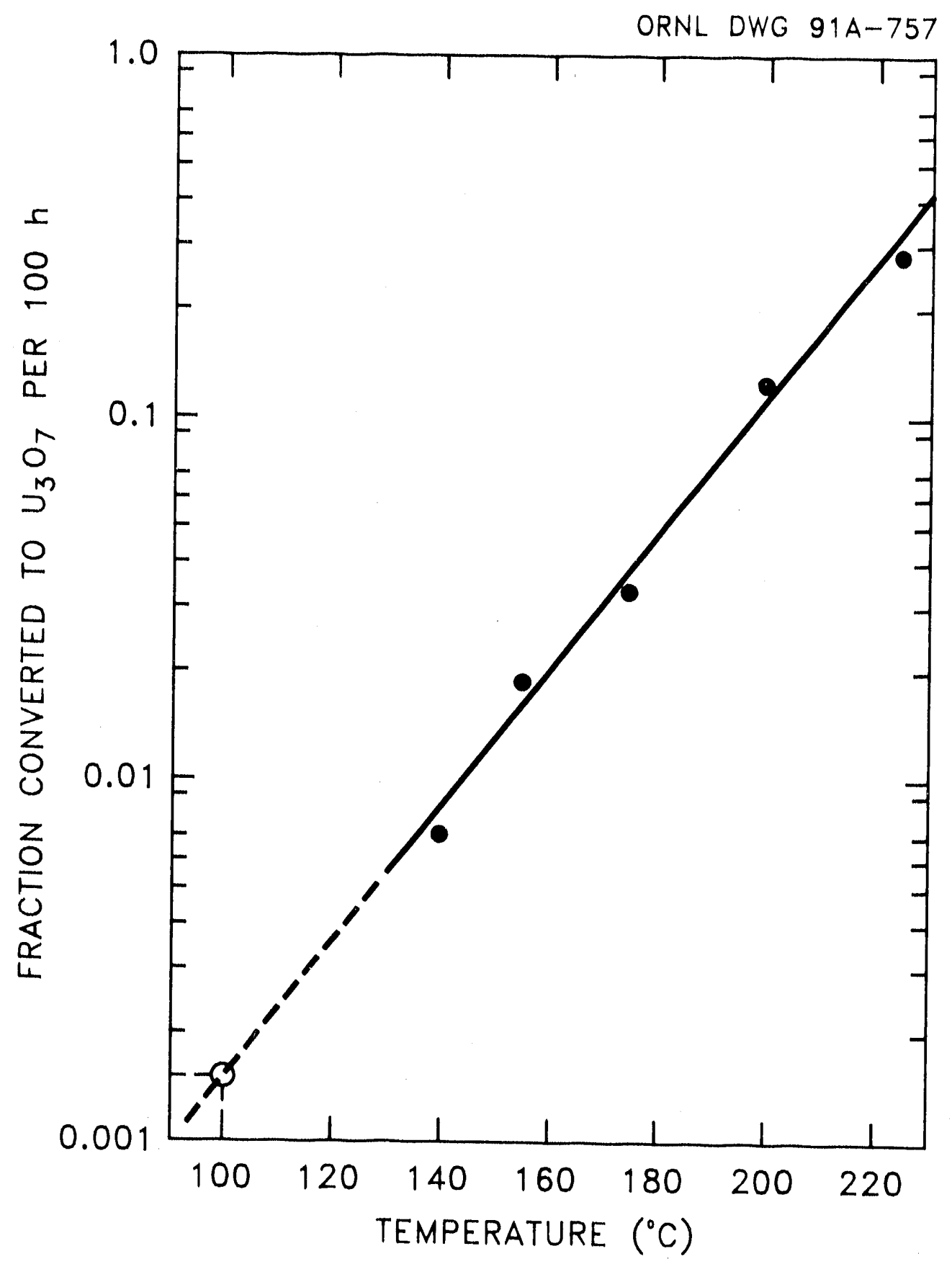

Fig. B.1. Air oxidation of $\mathrm{UO}_{2}$ to $\mathrm{U}_{3} \mathrm{O}_{7}$ as a function of temperature. 


$$
\begin{aligned}
\text { Mol of } \mathrm{O}_{2} & =\frac{70,000 \times 10^{6}}{238}(0.165) \\
& =48 \times 10^{6} \\
\text { MT of } O_{2} & =\frac{\text { moles } \times 32}{10^{6}}=1500 \\
M T \text { of air } & =5 \times M T \text { of } O_{2}=7500
\end{aligned}
$$

Using $1 \times 10^{-3} \mathrm{~g} / \mathrm{cm}^{3}$ as the approximate density of air at the Yucca Mountain site, $7500 \mathrm{MT}$ of air represent $7500 \times 10^{3} \mathrm{~m}^{3}$.

If it is assumed that, initially, only the $\sim(0.01 \%$ of projected leaker fuel is available to be oxidized, then $0.75 \mathrm{MT}$ (or $750 \mathrm{~m}^{3}$ ) of air would accomplish complete oxidation to $\mathrm{U}_{3} \mathrm{O}_{7}$. This could be the condition after 1000 years, the projected lifetime of the repository casks. After that, additional cladding failure can be anticipated. Eventually, and this will take many years, all of the fuel will be exposed to oxidation.

The rate of oxygen consumption can be calculated from the total capacity (as $\mathrm{U}_{3} \mathrm{O}_{7}$ ) and the fraction converted rates given in Table B.1. On an annual basis, the fraction converted is equal to 88 times the fraction per $100 \mathrm{~h}$, or $61 \%$ at $140^{\circ} \mathrm{C}$ and $13 \%$ at $100^{\circ} \mathrm{C}$. These percentages, when applied to the lotal capacity, yield 4600 MT of air per year at $140^{\circ}$ or $1000 \mathrm{MT}$ at $100^{\circ} \mathrm{C}$. At $140^{\circ} \mathrm{C}$, conversion to $\mathrm{U}_{3} \mathrm{O}_{7}$ will take about 1.6 years; at $100^{\circ} \mathrm{C}$, about 8 years. If only the $0.01 \%$ of initially-breached fuel is exposed to oxygen, then the rate will be less by a factor of $10^{4}$ but the conversion time (for the $0.01 \%$ ) will be the same as above. As additional cladding breaches, additional oxidation will occur.

\section{B.1. REFERENCES}

1. K. J. Notz and M. G. Mendel, "X-Ray and Kinetic Study of the Hydrogen Reduction of $\gamma$-UO ${ }_{3}$, J. Inorg. Nucl. Chem., 14, 55-64 (1960). 
2. K. J. Notz, C. W. Huntington, and W. Burkhardt, "Hydrogen Reduction of Uranium Oxides," Industrial and Engineering Chemistry Process Designs and Development, 1, 213 (1962).

3. J. S. Anderson, L. E. J. Roberts, and E. A. Harper, "The Oxides of Uranium, Part VII. The Oxidation of Uranium Dioxide," I. Chem. Soc. (London), $3946-59$ (1955).

4. S. Aronson, R. B. Roof, Jr., and J. Belle, "Kinetic Study of the Oxidation of Uranium Dioxide," The Journal of Chem. Physics, 17, (No. 1) 137-44 (1956).

5. P. E. Blackburn, J. Weissbart, and E. A. Gulbransen, 1958. "Oxidation of Uranium Dioxide," J. Phys. Chem., 62, $902-8$ (1958).

6. H. R. Hoekstra, A. Santoro, and S. Siegel, "The Low Temperature Oxidation of $\mathrm{UO}_{2}$ and $\mathrm{U}_{4} \mathrm{O}_{9}$, J. Inorg. Nucl. Chem., 18, 166-78 (1960).

7. E. Y. Walker, "The Oxidation of Uranium Dioxides," J. Appl. Chem., 15, 128 (1965).

8. R. E. Woodley, R. E. Einziger, and H. C. Buchanan, Nucl. Tech., 85, 74-88 (1989).

9. R. E. DeMarco, et al., "Oxidation of $\mathrm{UO}_{2}$ to $\mathrm{U}_{3} \mathrm{O}_{8}$," The American Ceramic Society Bulletin, 38, (No. 7), 360-2 (1959).

10. K. A. Peakall and J. E. Antill, "Oxidation of Uranium Dioxide in Air at $350-1000^{\circ} \mathrm{C}$," J. Nucl. Mater. 2, (No. 2), 194-5 (1960).

11. K. T. Scott and K. T. Harrison, "Some Studies of the Oxidation of Uranium Dioxide," $J$. Nucl. Mater. 8, (No. ?), 307-19 (1962). 


\section{APPENDIX C: OXIDATION OF GRAPHITE}

Graphite is chemically stable and nonreactive in air at ambient temperature and even at moderately elevated temperatures. This lact is clearly demonstrated by the occurrence of natural graphite and by the widespread use of manmade graphite in many applications. Lampblack and other finely divided (i.e., high surface area) forms of carbon were formerly thought to be amorphous but are now known to be microcrystalline graphite. These are somewhat more reactive than bulk graphite because of their high surface area. The surface of carbon blacks (and activated charcoals especially) are very receptive to the adsorption of polar molecules such as $\mathrm{SO}_{2}$ and $\mathrm{H}_{2} \mathrm{O}$, but not $\mathrm{O}_{2}$.

Because of its importance in commerce, the oxidation of graphite by air has been studied extensively. In order to achicve measurable oxidation rates, temperatures above $400^{\circ} \mathrm{C}$ are normally employed. More recently, the use of graphite as a neutron moderator (and material of construction) in reactors has prompled oxidation studies in support of accident analysis scenarios. Table C.1 lists temperature ranges and activation energies for two classical studies and one very recent (still ongoing in lact) study at ORNL. All of these studies used bulk manmade graphite, albeit small samples of less than a gram. However, the results obtained were shown to be representative of bulk graphite. For carbon blacks and thin streaks of graphite on an inert substrate, the activation energies were 65 and $80 \mathrm{kcal} / \mathrm{mol}$, respectively.

The rate data of Gulbransen and Andrew were reported in terms of grams of C oxidized per $\mathrm{cm}^{2}$ per second for a bulk specimen, a unit whicu can be applied directly to FSV fuel. Extrapolation to $150^{\circ} \mathrm{C}$ (Fig. C.1; this was also done analytically) gives a rate of $1.05 \times 10^{.17}$ $\mathrm{g}-\mathrm{C} / \mathrm{cm}^{2} / \mathrm{sec}$, or $33 \times 10^{11} \mathrm{~g}-\mathrm{C} / \mathrm{cm}^{2} / y e a r$. A single FSV fuel element has an area of $8133 \mathrm{in}^{2}$ which, for the total FSV inventory of 2214 elements, gives an area of $1.16 \times 10^{8} \mathrm{~cm}^{2}$. Combined with the above rate, this gives a calculated total oxidation rate of $3.8 \times 10^{-2} \mathrm{~g}$ of $\mathrm{C}$ per year, or $38 \mathrm{~kg}$ in $1.0 \times 10^{6}$ years. At $100^{\circ} \mathrm{C}$ the corresponding value is $163 \mathrm{~g}$ of $\mathrm{C}$ in one million years. After the first thousand years, the repository temperature will be lower than $100^{\circ} \mathrm{C}$. The work by Fuller, et al. is particularly germane to the present study because 
Table C-1. Graphitc Oxidation Studics

\begin{tabular}{lccc}
\hline Author(s) (ycar) & Temperature range $\left({ }^{\circ} \mathrm{C}\right)$ & $\mathrm{E}_{\mathrm{a}}(\mathrm{kcal} / \mathrm{mol})$ & Reference \\
\hline $\begin{array}{l}\text { Gulbransen } \\
\text { and Andrew (1952) }\end{array}$ & $425-575$ & 36.7 & 1 \\
$\begin{array}{l}\text { Blyholder } \\
\text { and Eyring (1957) }\end{array}$ & $600-130)$ & 42 & 2 \\
Fuller, et al. (1991) & $375-850$ & 40 & 3 \\
\hline
\end{tabular}




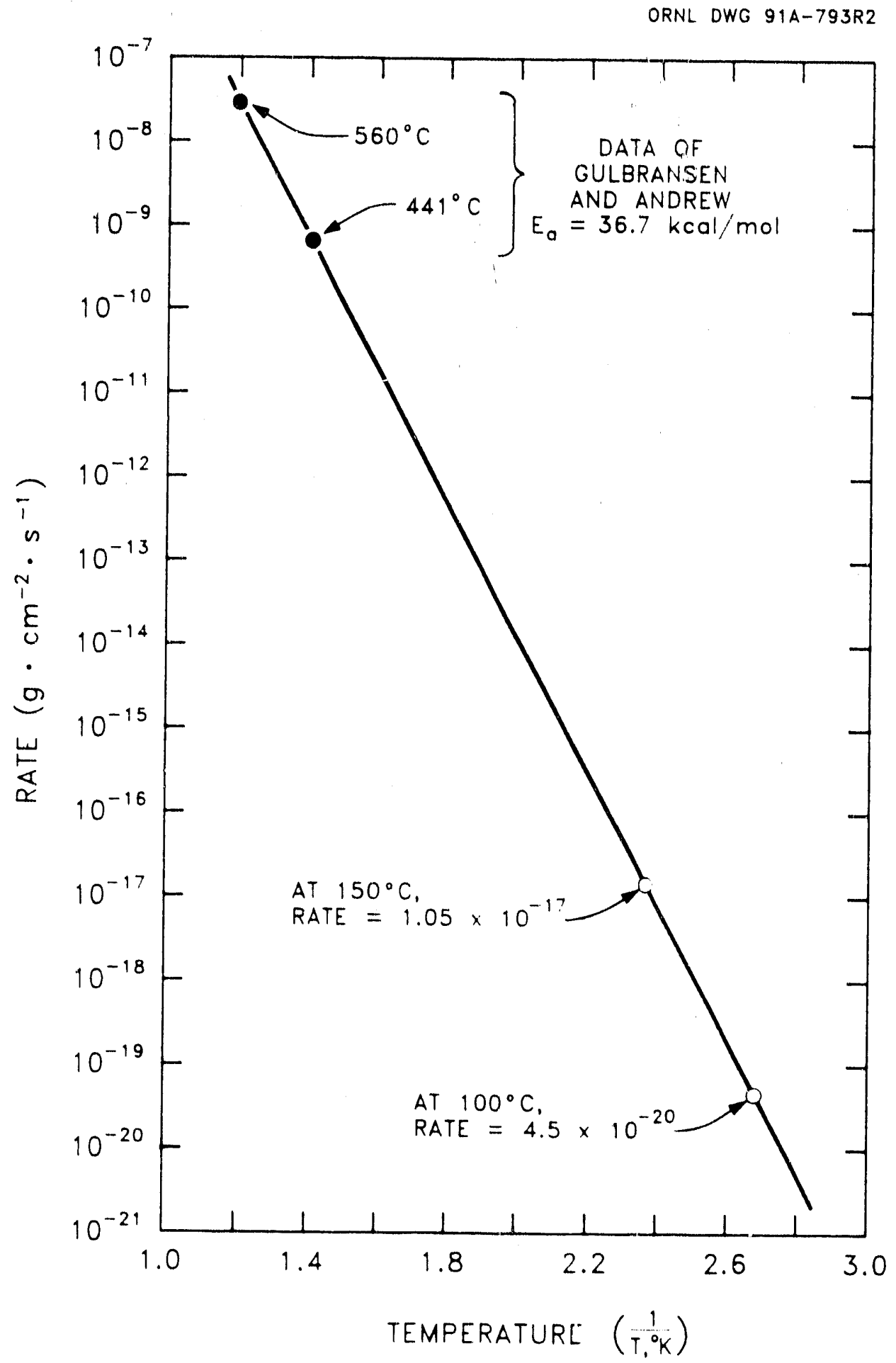

Fig. C.1. Oxidation of graphite at an oxygen pressure of $0.1 \mathrm{~atm}$. 
it utilized $\mathrm{H}-451$ graphite in an air atmosphere with a moisture content comparable to the Yucca Mountain site. Their rate data are reported as milligrams of $\mathrm{C}$ oxidized per minute, for a $1.77 \mathrm{~g}$ sample with a geometric surface area of $5.2 \mathrm{~cm}^{2}$. At $560^{\circ} \mathrm{C}$, Fuller's rate is about seven times faster than Gulbransen's based on the geometrical surface area. However, Gulbransen used single-crystal (naturally-occurring) graphite, so Fuller's apparent rate should be higher. Based on BET surface area, Fuller's rate is about 2.5 times slower than Gulbransen's. Considering the known sensitivity of graphite oxidation to the presence of impurities, this could be considered as good agreement. Further analysis is appropriate after Fuiler's work is completed. For now, a multiple of 7, applied to the rates calculated earlier, is probably appropriate.

The Eyring data are in terms of absolute reduction rate theory and do not lend themselves to direct comparison with the other data. However, further analysis of these data would be appropriate. Overall, extension of Fuller's work to clearly separate the effects of geometrical and BET surface areas should be interesting. However, the oxidation rate of graphite at ambient repository conditions is so slow that the interest is largely academic.

The low oxidation rates of graphite in air implies that graphite oxidation is not a controlling mechanism for failure of HTGR spent fuel in a repository. A sample calculation demonstrates this implication. In an HTGR fuel assembly, the fission products cannot be released until the graphite is breached and the $\mathrm{SiC}$ layer disrupted. The minimum amount of graphite between an air environment and the fuel is $-0.5 \mathrm{~cm}$. This is the distance between a fuel channel in the graphitc block and a coolant channel. The time required for air oxidation of the graphite at $150^{\circ} \mathrm{C}$ (maximum repository temperature) until exposure of the fuel microspheres using idealized conditions is calculated as follows:

Time $=[$ Graphite Thickness] $[$ Density of Graphite]/[Oxidation Rate]

$$
\begin{gathered}
=[0.5 \mathrm{~cm}]\left[2.26 \frac{\mathrm{g}}{\mathrm{cm}^{3}}\right] /\left[1 \times 10^{-17} \frac{\mathrm{g}}{\mathrm{cm}^{2} \cdot \mathrm{s}}\right] \\
=1.1 \times 10^{17} \mathrm{~s}=3.6 \times 10^{9} \text { years } .
\end{gathered}
$$




\section{C.1 REFERENCES}

1. E. A. Gulbransen and K. F. Andrew, "Reactions of Artificial Graphite," Industrial and Engineering Chemistry, 44, (No. 5) 1034-38 (1952).

2. G. Blyholder and H. Eyring, "Kinctics of Graphite Oxidation," J. of Phys. Chem., 61, 682-88 (1957).

3. E. L. Fuller, O. C. Kapp, and A. D. Underwood, Corrosion of Nuclear Grade Graphite: Air Oxidation of H-451, ORNL/GCR 91/xxx, Martin Marietta Energy Systems, Inc., Oak Ridge National Laboratory, (To be published). 
ORNL/TM-12027

IIC-522, 810, 811

\section{INTERNAL DISTRIBUTION}

$\begin{aligned} 1 . & \text { J. M. Begovich } \\ 2 . & \text { W. D. Bond } \\ 3 . & \text { A. G. Croff } \\ 4-5 . & \text { C. W. Forsberg } \\ 9 . & \text { E. L. Fuller } \\ 10 . & \text { R. W. Glass } \\ 11 . & \text { F. J. Homan } \\ 12 . & \text { H. Jones } \\ 13 . & \text { M. J. Kania } \\ 14 . & \text { H. T. Kerr } \\ 15 . & \text { K. H. King-Jones } \\ 16-20 . & \text { G. E. Michaels } \\ 21 . & \text { D. L. Moses }\end{aligned}$

22-26. K. J. Notz

27. P. L. Rittenhouse

28. O. M. Stansfield

29. M. G. Stewart

30. J. D. White

31. K. A. Williams

32-33. Central Research Library

34-35. Laboratory Records

36. Laboratory Records, RC

37. ORNI Y-12 Technical Library, Document ReferenceSection

38. ORNL Patent Section

\section{EXTERNAL DISTRIBUTION}

39. K. R. Absher, U.S. DOE, NP-32, 1000 Independence Aven ie, SW, Washington, D.C. 20585

40. C. Anderson, DOE, Savannah River Field Office, 703H, Room 117, Aiken, SC 29802

41. J. H. Ballowe, U.S. DOE, NP64, 1000 Independence Avenue, SW, Washington, D.C. 20585

42. G. C. Bramblett, MHTGR Project Division, General Atomics, P.O. Box 85608, San Diego, CA 92138

43. T. Britell, U.S. DOE, EM-341/BDM, 1000 Independence Avenue, SW, Washington, D.C 20585

44. S. J. Brown, U.S. DOE, NP-63, 1000 Independence Avenue, SW, Washington, D.C. 20585

45. J. M. Broughton, U.S. DOE, NP-2, 1000 Independence Avenue, SW, Washington, D.C. 20585

46. H. C. Burkholder, PNL, P.O. Box 999, Richland, WA 99342

47. B. Butcher, Sandia National Laboratories, Division 5245, Albuquerque, NM 871855800 
48. P. Castle, U. S. DOE, EM-351/WINCO, 1000 Independence Avenue, SW, Washington, D.C. 20585

49. H. Chamberlain, U.S. DOE, DP-27/WINCO, 1000 Independence Avenue, SW, Washington, D.C. 20585

50. H. W. Chi, EG\&G Idaho, 1580 Sawtelle St., M/S 2511, Idaho Falls, ID 83415

51. N. Chipman, WINCO-INEL, P.O. Box 4000, Mail Stop 5213, Idaho Falls, ID 83403

52. E. C. DeLeon, U.S. DOE, NP-63, 1000 Independence Avenue, SW, Washington, D.C. 20585

53. P. J. Dirkmaat, U.S. DOE, NP-80, 1580 Sawtelle St., M/S 2519, Idaho Falls, ID 8.3415

54. G. A. Dinnean, EG\&G Idaho, 1580 Sawtelle St., M/S 2511, Idaho Falls, ID 83415

55. R. W. Englehare, U.S. DOE, NP-50, 1000 Independence Avenue, SW, Washington, D.C. 20585

56. B. Fortune, U. S. DOE, EM-231, 1000 Independence Avenue, SW, Washington, D.C. 20585

57. R. M. Forssell, CEGA Corporation, P.O. Box 85608, San Diego, CA 92138

58. J. E. Fox, U.S. DOE, NE-15, E-478, 19901 Germantown Road, Germantown, MD 20545

59. G. Frandsen, WINCO-INEL, P.O. Box 4000, Idaho Falls, ID 83403

60. S. M. Franks, Office of Gas-Cooled Reactors, Department of Energy, NP-61, Room 1H050, 1000 Independence Avenue, SW, Washington, DC. 20585

61. M. L. Gates, U.S. DOE, NP-64, 1000 Independence Avenue, SW, Washington, D.C. 20585

62. J. Gerstein, U.S. DOE, EM-35, 1000 Independence Avenue, SW, Washington, D.C. 20585

63. M. W. Golay, Dept. of Nuclear Engineering, Massachusetts Institute of Technology, 77 Massachusetts Avenue, Cambridge, MA 02139

64. F. Goldner, US DOE, NE-45, 19901 Germantown Road, Germantown, MD 20874 
65. H. Gotschall, Gas-Cooled Reactor Associates, 11240 Sorrento Valley Road, Suite 300, San Diego, CA 92121-1605

66. M. Guinan, U.S. DOE, ER-13, 1000 Independence Avenuc, SW, Washington, D.C. 20585

67. F. Harrington, 8125 Chesterficld Drive, Knoxville, TN 37909

68. R. Hastings, U. S. DOE, Post Office Box 550, Mail Stop A-655, Richland, WA 99352

69. M. Heigh, U.S. DOE, EM-341/323/BDM, 1000 Indeperidence Avenue, SW, Washington, D.C 20585

70. D. F. Hoel, U.S. DOE, NP-53, 1000 Independence Avenue, SW, Washington, D.C 20585

71. J. J. Jicha, Jr., U.S. DOE, NP-40, 1000 Independence Avenue, SW', Washington, D.C 20585

72. P. Karc 2, U.S. DOE, NE-40, 1000 Independence Avenue, SW, Washington, D.C. 20585

73. M. C. Kirkland, U.S. DOE, NP-70, 35 Varden Drive, Aiken, SC 29802

74. K. A. Klein, U.S. DOE, NP-30, 1000 Independence Avenue, SW, Washington, D.C. 20585

75. D. Knecht, Idaho Chemical Processing Plant, WINCO, P.O. Box 4000, MF 5213, Idaho Falls, ID 83403

76. R. Kuhl, U.S. DOE, EM-54, 1000 Independence Avenue, SW, Washington, D.C. 20585

77. R. K. Lane, CEGA Corporation, P.O. Box 85608, San Diego, CA 92138

78. D. Lanning, Dept. of Nuclear Engineering, Massachusetts Institute of Technology, 77 Massachusetts Avenue, Cambridge, MA 02139

79. L. Lidsky, Dept. of Nuclear Engineering, Massachusetts Institute of Technology, 77 Massachusetts Avenue, Cambridge, MA 02139

80. A. L. Lotts, 849 Chateaugay Road, Knoxville, TN 37919

81. L. D. Mears, Gas-Cooled Reactor Associates, 10240 Sorrento Valley Road, Suite 300, San Diego, CA 92121-1605 
82. R. R. Mills, MHTGR Plant Design Control Office - East, 3206 Tower Oaks Blvd, Suite 300, Rockville, MD 20852

83. R. A. Moore, U.S. DOE, NP-63, 1000 Independence Avenue, SW, Washington, D.C. 20585

84. R. Natoli, U.S. DOE, EH-222, 1000 Independence Avenue, SW, Washington, D.C. 20585

85. J. Neave, U.S. DOE, EM-323, 1000 Independence Avenue, SW, Washington, D.C. 20585

86. G. E. Nelson, U.S. DOE, 785 DOE Place, MS-1139, Idaho Falls, ID 83401

87. A. J. Neylan, CEGA Corporation, P.O. Box 85608, San Diego, CA 92138-5608

88. H. Nigam, U.S. DOE, EH-25, 1000 Independence Avenue, SW, Washington, D.C. 20585

89. J. D. Nulton, Director, Office of Gas-Cooled Reactors, Department of Energy, NP60, Room 1H087, 1000 Independence Avenue, SW, Washington, DC 20585

90. A. Olson, WINCO-INEL, P.O. Box 4000, MS 3412, Idaho Falls, ID 83403

91. B. Owca, Idaho Field Office, 785 DOE Place, MS-1235, Idaho Falls, ID 83402

92. L. Papouchado, Westinghouse Savannah River Co., Savannah River Lab., P.O. Box 616, Aiken, SC 29208

93. P. J. Ritzcoven, U.S. DOE, NP-52, 1000 Independence Avenue, SW, Washington, D.C. 20585

94. C. G. Robertson, U.S. DOE, NP-62, 1000 Independence Avenue, SW, Washington, DC 20585

94. G.W. Roles, U.S. DOE, EH-232, 1000 Independence Avenue, SW, Washington, D.C. 20585

95. S. Rosen, U.S. DOE, 19901 Germantown Road, Germantown, MD 20874

96. J. Schmidt, Westinghouse Hanford, P.O. Box 1970, Mail Stop X0-41, Richland, WA 99352

97. D. Shelor, U.S. DOE, RW-3, 1000 Independence Avenue, SW, Washington, D.C. 20585 
98. G. Sjoblom, U.S. DOE, EM-1, 1000 Independence Avenue, SW, Washington, D.C. 20585

99. B. A. Smith, U.S. DOE, DP-635, 1000 Independence Avenue, SW, Washington, D.C. 20585

100. F. H. Southworth, EG\&G Idaho, 1580 Sawtelle St., M/S 2511, Idaho Falls, ID 83415

102. R. Stecle, U.S. DOE, NE-60 [NR], 1000 Independence Avenuc, SW, Washington, D.C. 20585

103. O. W. Taylor, U.S. DOE, NP-64, 1000 Independence Avenue, SW, Washington, D.C. 20585

104. G. Tingey, Pacific: Northwest Laboratory, P.O. Box 999, Mail Stop PA-10, Richland, WA 99352

105. E. G. Tourigney, U.S. DOE, NP-60, 1000 Independence Avenue, SW, Washington, D.C. 20585

106. O. Truskett, U.S. DOE, EM-343 [309 Trevion II], 1000 Independence Avenue, SW, Washington, D.C. 20585

107. R. F. Turner, General Atomics, P.O. Box 85608, San Diego, CA 92186-9784

108. R. M. Waage, EG\&G Idaho, 1580 Sawtelle St., M/S 2511, Idaho Falls, ID 83415

109. H. F. Walter, U.S. DOE, EM-351 [368 Trevion II], 1000 Independence Avenue, SW, Washington, D.C. 20585

110. C. Webber, U.S. DOE, 19901 Germantown Road, Germantown, MD 20874

111. P. M. Williams, Division of HTGRs, U.S. DOE, Office of Advanced Reactor Programs, 19901 Germantown Road, Germantown, MD 20874

112. R. Williams, Electric Power Research Institute, 3412 Hillview Avenue, Palo Alto, CA 94303

113. S. Wolf, U.S. DOE, EM-354 [413 Trevion II], 1000 Independence Avenue, SW, Washington, D.C. 20585

114. R. G. Wymer, 188-A Outer Drive, Oak Ridge, TN 37831

115. H. J. Zeile, Manager, New Production Reactor Department, EG\&G Idaho, Inc., P.O. Box 1625, Idaho Falls, ID 83415 
114

116. Caulton L. Irwin, Energy and Water Research Center, West Virginia University, Morgantown, WV 26506-6064

117. Alvin Weinberg, 111 Moylan Lane, Oak Ridge, TN 37830

118. Office of Assistant Manager, Energy Research and Development, DOE-OR, P.O. Box 2001, Oak Ridge, TN 37831

119-346. Given distribution as shown in TIC-4500 in Category UCN-522, $-810,-811$. 

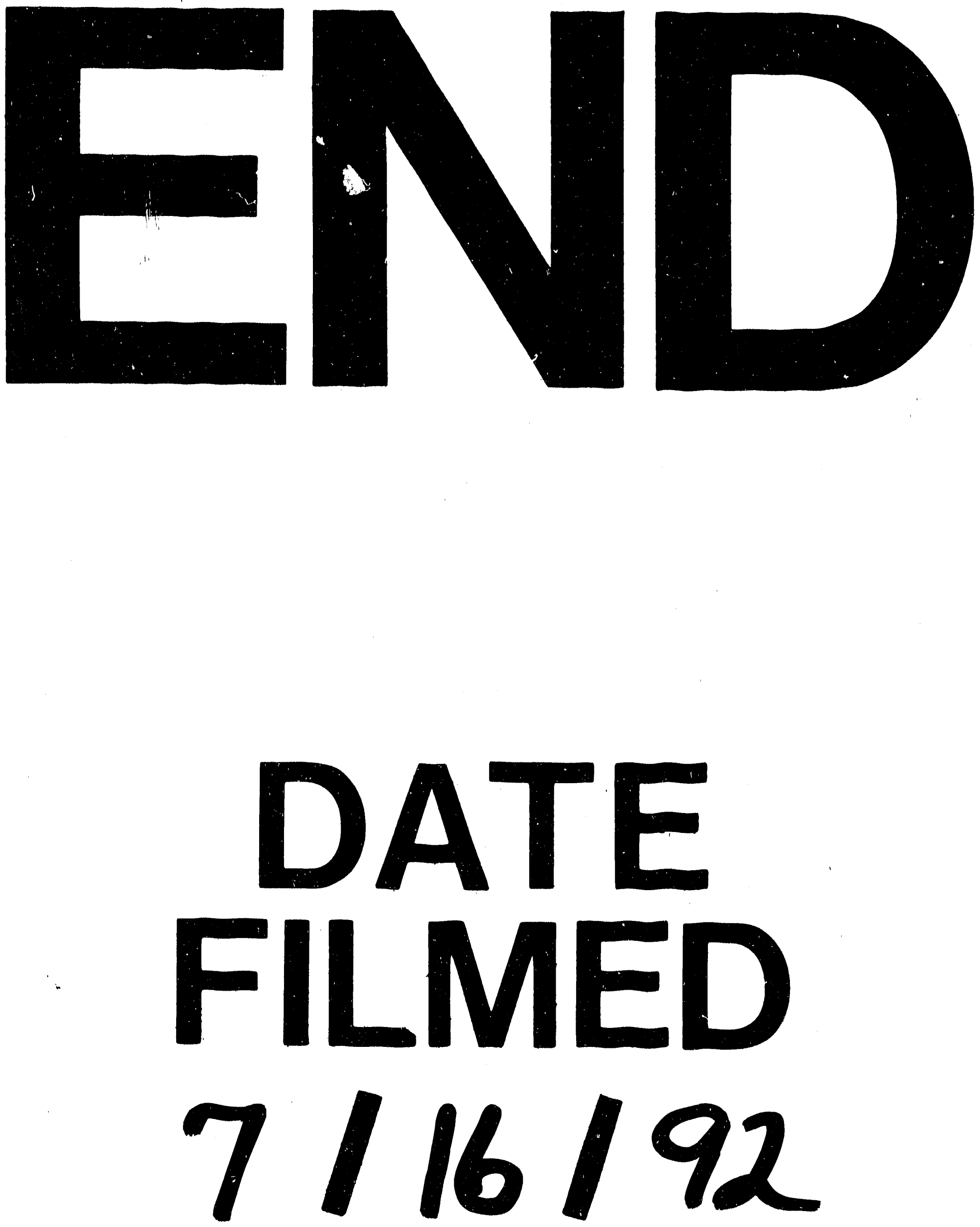
